\title{
Etiological issues of depression post myocardial infarction : linking heart and mind
}

Citation for published version (APA):

Schins, A. M. (2004). Etiological issues of depression post myocardial infarction : linking heart and mind. [Doctoral Thesis, Maastricht University]. Wetenschapskring. https://doi.org/10.26481/dis.20040527as

Document status and date:

Published: 01/01/2004

DOI:

10.26481/dis.20040527as

Document Version:

Publisher's PDF, also known as Version of record

\section{Please check the document version of this publication:}

- A submitted manuscript is the version of the article upon submission and before peer-review. There can be important differences between the submitted version and the official published version of record.

People interested in the research are advised to contact the author for the final version of the publication, or visit the DOI to the publisher's website.

- The final author version and the galley proof are versions of the publication after peer review.

- The final published version features the final layout of the paper including the volume, issue and page numbers.

Link to publication

\footnotetext{
General rights rights.

- You may freely distribute the URL identifying the publication in the public portal. please follow below link for the End User Agreement:

www.umlib.nl/taverne-license

Take down policy

If you believe that this document breaches copyright please contact us at:

repository@maastrichtuniversity.nl

providing details and we will investigate your claim.
}

Copyright and moral rights for the publications made accessible in the public portal are retained by the authors and/or other copyright owners and it is a condition of accessing publications that users recognise and abide by the legal requirements associated with these

- Users may download and print one copy of any publication from the public portal for the purpose of private study or research.

- You may not further distribute the material or use it for any profit-making activity or commercial gain

If the publication is distributed under the terms of Article $25 \mathrm{fa}$ of the Dutch Copyright Act, indicated by the "Taverne" license above, 
Etiological issues of depression post myocardial infarction

\author{
Linking heart and mind
}


The Myocardial INfarction and Depression - Intervention Trial (MIND-IT) and the substudies of the MIND-IT presented in this thesis were sponsored by grant no. 97.016 and grant no. 2022B207 of the "Netherlands Heart Foundation", by a grant of Organon NV and a grant of Lundbeck B.V.

ISBN: $90-6464019 \cdot \mathrm{X}$

O 2004. AM Schins

No part of this book may be reproduced or transmitted in any form or by any means, without written permission of the author, or when appropriate, the publisher of the article. 


\title{
Etiological issues of depression post myocardial infarction
}

\author{
Linking heart and mind
}

\author{
PROEFSCHRIFT \\ ter verkrijging van de graad van doctor aan de \\ Universiteit Maastricht op gezag van de Rector Magnificus \\ Prof. mr. G. P. M. F. Mols \\ volgens het besluit van het College van Decanen \\ in het openbaar te verdedigen op donderdag \\ 27 mei 2004 om 14.00 uur \\ door
}

Annique Miriam Schins

geboren te Tegelen 


\section{Promotor:}

Prof. dr. J. van Os

\section{Co-promotor:}

Dr. A. Honig

\section{Beoordelingscommissie:}

Prof. dr. R-J. M. Brummer (voorzitter)

Prof. dr. H. J. G. M. Crijns

Prof. dr. E. J. L. Griez

Prof. dr. DrSc. K. Van Laere (Universiteit van Leuven)

Prof. dr. A. H. Schene (Universiteit van Amsterdam)

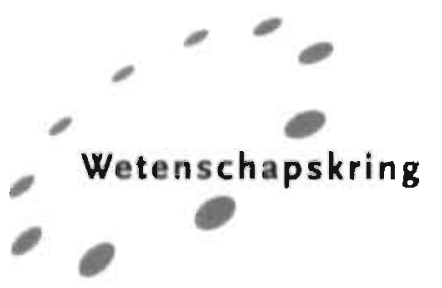

. South-Limburg Mental Health Research and Teaching Network PhD Series :

The following investigators and institutions in The Netherlands participated in the MIND-IT study:

Steering Committee: AH Schene MD PhD, A Honig MD PhD MRCPsych, HJGM Crijns MD PhD, J Ormel $\mathrm{PhD}$ (principal investigator). Study Coordination: $\mathrm{P}$ de Jonge $\mathrm{PhD}$, JP van Melle MD. Data management: Trial Coordination Center (TCC), Groningen, The Netherlands. Clinical centers: Flevo Hospital, Almere: ASJM Sadee MD, LM Konijnenberg MD. Academic Medical Center, Amsterdam: G Casteelen MD, AMG Kuyper MD, RJG Peters MD PhD, Slotervaart Hospital, Amsterdam: M Bax MD. Nij Smellinghe Hospital, Drachten: $\mathrm{M}$ van der Linde MD PhD, H Teunenbroek MD. Medical Spectrum Twente, Enschede: DG Buiten MD, GP Molhoek MD PhD. University Hospital Groningen: JA den Boer MD PhD, JF May MD PhD. Tjongerschans Hospital, Heerenveen: HP den Daas MD, DG Jochemsen MD. Atrium Medical Center, Heerlen: LHB Baur MD PhD, CJM van den Berg MD PhD. Medical Center Leeuwarden: DM Tulner MD, CJ de Vries MD. University Hospital Maastricht: A Honig MD PhD MRCPsych, PMJC Kuijpers MD, A Schins MD. 
Ter gedachtenis aan mijn vader Voor mijn moeder, Juleon en Anton Voor Marieke, Anoushka en. Maaike 



\section{Contents}

Prologue

\section{Part 1- PUFAs}

Chapter 1 Polyunsaturated fatty acids: the missing link between cardiac events and depression?

Acta Neuropsych 2001.13: 38-45

Chapter 2 Altered omega-3 polyunsaturated fatty acids in depressed post-myocardial infarction patients.

Submitted JACC

\section{Part 2- Platelets and serotonin}

Chapter 3 Increased coronary events in depressed cardiovascular patients: $5-\mathrm{HT}_{2 \mathrm{~A}}$ receptor as missing link?

Psychosom Med 2003,65: 729-737

Chapter 4 Whole blood serotonin and platelet activation in depressed post-myocardial infarction patients.

Submitted Life Sciences

\section{Part 3- Brain SPECT study in depressed post-MI patients}

Chapter 5 Increased cerebral $5 \mathrm{HT}_{2 \mathrm{~A}}$ receptor binding in depressed patients with myocardial infarction.

Submitted Biol Psych

\section{Part 4- Immune system}

Chapter 6 Inflammatory markers in depressed post-myocardial infarction patients.

Submitted J Psych Res

\section{Chapter 7 Epilogue}

Summary

Samenvatting

Dankwoord 



\section{Prologue}

Depression in the post myocardial infarction (MI) period is associated with increased cardiac morbidity and mortality ${ }^{1-10}$. In the post-MI period the prevalence of major and minor depression is about $13-20 \%{ }^{1,11-14}$, raising to $20-30 \%$ one year post MI ${ }^{12,15}$. Adjusted relative risk for cardiac mortality in depressed post-Ml patients ranges from 4.3 in older studies ${ }^{1.2}$ to $2.3-3.0^{7.16}$ in more recent ones. This increased risk is independent of other post-MI risk factors such as left ventricular dysfunction, complex arrhythmias, and history of prior MI. Not only depression but also other affective dysregulation related states such as type-D personality ${ }^{17}$, vital exhaustion ${ }^{18,19}$ and anxiety ${ }^{20.21}$ have been identified as risk factors for the course of coronary artery disease (CAD). As a result, attention is now devoted to studying the link between mood states and cardiovascular diseases. Pathophysiological mechanisms underlying the association between CAD and mood states remain unclear. This thesis is a contribution to the discussion of some key neurobiological alterations that may underlie the association of a specific form of mood dysregulation and CAD, more specific, the relation between depression and $\mathrm{MI}$.

First, an unfayourable balance berween omega 3 (n-3) and omega 6 polyunsaturated fatty acids (PUFAs) has been proposed as one of the mechanisms involved in the pathogenesis of both depression and MI. Depletion of omega-3 PUFAs has been reported in patients with major depression ${ }^{22-24}$. Mechanisms have been postulated by which n-3. PUFAs may influence the neurobiology of depression ${ }^{25}$. These include 1) increase of serotonin mediated neurotransmission 2) decrease of activation of the hypothalamic-pituitary- adrenal (HPA) axis and 3) decrease of immune activation. On the other hand, low mortality rates of CAD in populations with high dietary intake of fish oils, and consequently high intake of n-3 PUFAs, led to the hypothesis that consumption of these fatty acids reduces coronary heart disease ${ }^{26,27}$. Several clinical cardiovascular trials reported the beneficial effects of high intake of oily fish ${ }^{28,29}$. Cardioprotective effects of 
omega-3 PUFAs appear to reside in antiarrhythmic, antithrombotic, anti-inflammatory and antiatherogenic properties ${ }^{30-32}$.

Another mechanism that has been proposed as one of the mechanisms involved in the pathogenesis of both depression and MI, comes from recent developments in psycho-neuro-immunology. Major depression has been suggested to be associated with immune system abnormalities, such as increased levels of interleukin-1 $\beta$ (II-1 $\beta$, tumor necrosis factor $\alpha$ (TNF- $\alpha$ ) and II-6 ${ }^{33-38}$. When TNF$\alpha$ is administered in humans, it results in an increase in depressive symptoms such as fatigue, malaise, lethargy and anorexia ${ }^{39}$. Immune changes are not only related to depressive symptoms, but are also linked to the cardiovascular system. Atherosclerosis has been identified as an inflammatory process ${ }^{40}$ and increased levels of inflammatory markers such as C-reactive protein (CRP), II-6 and TNF- $\alpha$ have been associated with risk of future $\mathrm{MI}^{41}$ and recurrent coronary events after MI ${ }^{42}$.

Last but not least, major depression has been associated with central serotonergic neurotransmission dysfunction ${ }^{43,44}$. Statuses of different serotonin receptors, most notably the 5-HT transporter and the $5-\mathrm{HT}_{2 \mathrm{~A}}$ receptor, have not been conclusively shown in patients with depressive disorder. There are data showing that depression is associated with upregulation of $5-\mathrm{HT}_{2 \mathrm{~A}}$ receptors both centrally (in the brain) and in the periphery (on platelets). The correlation between platelet 5-HT and central 5-HT receptors needs further invesuigation. Upregulation or an increased sensitivity of $5-\mathrm{HT}_{2 \mathrm{~A}}$ receptors on platelet membranes and vascular endothelium may mediate atherogenic and prothrombotic mechanisms in the periphery ${ }^{45,46}$. Therefore increased platelet activation is a third factor that has been proposed explaining the link between depression and increased cardiac death after MI.

Biological alterations have been studied in either depressed populations or cardiovascular compromised patients. In order to study the above mentioned hypotheses further, in this thesis PUFA status, platelet activation parameters and immune status were studied in a group of depressed post-MI patients as compared to non-depressed post-MI patients. Next a brain imaging study was performed looking at $5 \mathrm{HT}_{2 \mathrm{~A}}$ binding patterns in depressed post-MI patients as compared to non-depressed post-MI patients. Collection of blood samples was part of a large multicenter study in post-MI patients. Before resuming the different chapters in this thesis, background information is provided about this multicenter study. 


\section{Background}

In line with findings from (i) the efficacy and safety study of fluoxetine in depressed post-MI patients from Strik et al. ${ }^{47}$ (ii) the SADHART study (an placebo-controlled efficacy and safety study of sertraline for the treatment of post-MI depression) ${ }^{48}$ and (iii) the ENRICHD study (a trial studying the efficacy of cognitive behavior therapy versus care-as usual for patients with post-MI depression and low perceived social support) ${ }^{49}$, the Myocardial INfarction and Depression Intervention Trial (MIND-IT) was initiated to evaluate the influence of antidepressive treatment versus care-as-usual for post-MI depression on cardiac prognosis ${ }^{50}$. Intervention consisted of double blind treatment with placebo or mirtazapine, an antidepressant with dual action, enhancing both serotonin and noradrenaline neurotransmission, or as second option, an open treatment with citalopram, a selective serotonin re-uptake inhibitor (SSRI). Most data presented in this thesis are derived from patients participating in the MIND-IT study.

\section{Aims and outlines of the study}

The main part of this thesis investigates possible pathophysiological mechanisms underlying the link between depression and MI and more specific various biological parameters which have been associated with both cardiovascular disease and depression. Patients participating in the double blind trial were asked for additional blood collection at two time points: once before start of treatment and once after 8 weeks treatment with mirtazapine or placebo. The control group consisted of matched non-depressed post-MI patients, who were asked for blood collection at only one time point.

In the first part of this thesis (chapter I and 2), the association between polyunsaturated fatty acid levels and depression post-MI is investigated.

First, a review of the relation between PUFAs and cardiovascular disease and on the other hand PUFAs and depressive illness is given, and second, data from a cross-sectional study are presented. An analysis is done regarding PUFA levels in depressed post-MI patients as compared to nondepressed post-MI patients. The relation between parameters of immune activation (CRP, II-6 and zinc) and PUFA levels are also given.

In the second part (chapter 3. and 4) first a review on platelet activation in depression is presented and second, data on platelet activation are discussed as measured by platelet factor 4 , beta- 
thromboglobulin and soluble CD40 ligand in depressed post-MI patients as compared to nondepressed post-MI patients.

In part 3 (chapter 5) the results of a brain imaging study looking at $5 \mathrm{HT}_{2 \mathrm{~A}}$ receptor binding in (depressed) post-MI patients are shown.

In part 4 (chapter 6) the association between various parameters of immune activation and depression post-MI is investigated.

in chapter 7 a summary of findings and a general discussion of combined results are given. 


\section{References}

1. Frasure-Smith N, Lesperance F, Talajic M. Depression following myocardial infarction: impact on 6months survival. JAMA. 1993:270:1819-1825.

2. Ladwig $\mathrm{KH}$, Kieser M, Konig J, Breithardt G, Borggrefe M. Affective disorders and survival after acute myocardial infaretion (results from the post-infarction late potential study). Eur Heart J. 1991:12:959-964.

3. Jiang W, Alexander J, Christopher E, Kuchibhatla M, Gaulden L. Cuffe M. Blazing M. Davenport C. Califf R, Krishnan R, O'Connor CM. Relationship of Depression to Increased Risk of Mortality and Rehospitalization in Patients With Congestive Heart Failure. Arch Intern Med. 2001:161:1849-1856.

4. Abramson J, Berger A, Krumholz HM, Vaccarino V. Depression and risk of heart failure among older persons with isolated systolic hypertension. Arch Intern Med. 2001:161:1725-30.

5. Denollet J. Personality and mortality after myocardial infaretion. Psychosom Med. 1995:57:582-591.

6. Barefoot JC, Schroll M. Symtomps of depression, acute myocardial infaretion, and total mortality in a community sample. Circulation. 1996;93:1976-1980.

7. Bush DE, Ziegelstein RC, Tayback M, Richter D, Stevens S, Zahalsky H, Fauerbach JA. Even minimal symptoms of depression increase mortality risk after acute myocardial infaretion. Am $J$ Cardiol. 2001:88:337-41.

8. Ariyo AA, Haan M, Tangen CM, Rutledge JC, Cushman M, Dobs A, Furberg CD. Depressive symptoms and risks of coronary heart disease and mortality in elderly Americans. Circulation. 2000;102:1773-9.

9. Welin C, Lappas G. Wilhelmsen L. Independent importance of psychosocial factors for prognosis after myocardial infarction. J Intern Med. 2000;247:629-39.

10. Irvine J, Basinski A, Baker B, Jandeiu S, Paquette M, Caims J, Connolly S, Roberts R, Gent M, Dorian P. Depression and risk of sudden cardiac death after acute myocardial infaretion: testing for the confounding effects of fatigue. Psychosom Med. 1999;61:729-37.

11. Ladwig KH, Roll G, Breithardt G, Budde T, Borgerefe M. Post infaret depression and incomplete recovery 6 months after acute myocardial infarction. The Lancet. 1994;343:20-23.

12. Forrester AW, Lipsey JR, Teitelbaum ML, DePaulo JR, Andrzejeweski PL. Depression following myocardial infarction. Int J Psychiatry Med. 1992;22:33-46.

13. Strik JJ, Denollet J, Lousberg R, Honig A. Personality and vulnerability to depression following myocardial infarction: a prospective follow-up study. Am J Psychiatry. 2003;in press.

14. Strik JJ, Lousberg R, Cheriex EC, Honig A. One year cumulative incidence of depresssion following myocardial infarction and impact on cardiac outcome, J Psychosom Res. 2003, in press.

15. Honig A, Lousberg R, Wojchiechowski F, Cheriex EC, Wellens H, Van Praag HM. Depression following a first myocardial infarction; similarities with and difference from 'ordinary' depression (Depressie na een eerste hartinfarct: overeenkomsten en verschillen met een gewone depressie). Ned Tijdschr Geneeskunde. 1997;141:196-199.

16. Penninx BW, Beekman AT, Honig A, Deeg DJ, Schoevers RA, van Eijk IT, van Tilburg W. Depression and cardiac mortality: results from a community-based longitudinal study. Arch Gen Psychiatry. 2001:58:221-7.

17. Denollet J, Sys SU, Stroobant N, et al. Personality as independent predictor of long-term mortality in patients with coronary heart disease. Lancet. 1996;347:417-421.

18. Kop WJ, Appels A, Mendes de Leon CF, Swart de H, Bar F. Vital exhaustion predicts new cardiac events after successful coronary angioplasty. Psychosomatic Medicine. 1994:281-287.

19. Kop WJ, Appels APWM, Mendez de Leon CF, Bar FW. The relationship between severity of coronary artery disease and vital exhaustion. Journal of Psychomatic Research. 1996:40:397-405.

20. Strik JJ, Denollet J, Lousberg R. Honig A. Comparing symptoms of depression and anxiety as predictors of cardiac events and increased health care consumption following myocardial infarction. $J A C C .2003$; in press.

21. Kubzansky LD, Kawachi I, Weiss ST, Sparrow D. Anxiety and coronary heart disease: a synthesis of epidemiological, psychological, and experimental evidence. Ann Behav Med. 1998;20:47-58. 
22. Peet M, Murphy B, Shay J, Horrobin D. Depletion of omega-3 fatty acid levels in red blood cell membranes of depressive patients. Biol Psychiatry. 1998;43:315-9.

23. Adams PB, Lawson S, Sanigorski A, Sinclair AJ. Arachidonic acid to eicosapentaenoic acid ratio in blood correlates positively with clinical symptoms of depression. Lipids. 1996;31 (Suppl):S157-61.

24. Maes M, Smith R, Christophe A, Cosyns P, Desnyder R, Meltzer H. Fatty acid composition in major depression: decreased $n 3$ fractions in cholesteryl esters and increased $C 20: 4 n 6 / C 20: 5 n 3$ ratio in cholesteryl esters and phospholipids. J Affect Dis. 1996;38:35-46.

25. Hibbeln J. Long-chain Polyunsaturated fatty Acids in Depression and related Conditions. In: Phospholipid Spectrum Disorder in Psychiatry. Lancashire: Marius Press; 1999:195-209.

26. Kromhout D, Bosschieter EB, de Lezenne Coulander C. The inverse relation between fish consumption and 20-year mortality from coronary heart disease. $N$ Engl J Med. 1985;312:1205-9.

27. Ascherio A, Rimm EB, Stampfer MJ, Giovannucci EL, Willett WC. Dietary intake of marine n-3 fatty acids, fish intake, and the risk of coronary disease among men. $N$ Engl $J$ Med. 1995:332:97782.

28. Burr ML, Fehily AM, Gilbert JF, Rofers S, Holliday RM, Sweetnam PM, Elwood PC, Deadman NM. Effects of changes in fat, fish and fibre intakes on death in myocardial reinfaretion: diet and reinfaretion trial. Lancet. 1989:2:757-761.

29. Investigators G-P. Dietary supplementation with $\mathrm{n}-3$ polyunsaturated fatty acids and vitamin $\mathrm{E}$ after myocardial infarction: results of the GISSI-Prevenzione trial. Lancet. 1999;354:447-55.

30. Vericel E, Calzada C, Chapuy P, Lagarde M. The influence of low intake of n-3 fatty acids on platelets in elderly people. Atherosclerosis. 1999;147:187-92.

31. Calder PC. Immunoregulatory and anti-inflammatory effects of n-3 polyunsaturated fatty acids. Braz J Med Biol Res. 1998;31:467-90.

32. Leaf A, Kang JX, Xiao YF, Billman GE. Clinical prevention of sudden cardiac death by n-3 polyunsaturated fatty acids and mechanism of prevention of arrhythmias by n-3 fish oils. Circulation. 2003;107:2646-52.

33. Sluzewska A, Rybakowski J, Bosmans E. Indicators of immune activation in major depression. Psychiatry Research. 1996;64:161-167.

34. Van Der Ven A, Van Diest R, Hamulyak K, Maes M, Bruggeman C, Appels A. Herpes viruses, cytokines, and altered hemostasis in vital exhaustion. Psychosom Med. 2003;65: 194-200.

35. Mikova O, Yakimova R, Bosmans E, Kenis G, Maes M. Increased serum tumor necrosis factor alpha concentrations in major depression and multiple sclerosis. Eur Neuropsychopharmacol. 2001:11:203-8.

36. Honig A, Maes M. Psychoimunology as a common pathogenetic pathway in myocardial infarction, depression and cardiac death. Curr Opin Psychiatry. 2000;13:661-664.

37. Maes M, Bosmans E, De Jongh R, Kenis G, Vandoolaeghe E, Neels H. Increased serum IL-6 and IL1 receptor antagonist concentrations in major depression and treatment resistant depression. Cytokine. 1997;9:853-8.

38. Maes M. Meltzer HY, Bosmans E, Bergmans R, Vandoolaeghe E, Ranjan R, Desneyder R. Increased plasma concentrations of interleukin-6, soluble interleukin-6 receptor, soluble interleukin-2 and transferrin receptor in major depression. Journal of Affective Disorders. 1995;34:301-309.

39. Spriggs DR, Sherman ML, Michie H, Arthur KA, Imamura K, Wilmore D, Frei E, 3rd, Kufe DW. Recombinant human tumor necrosis factor administered as a 24-hour intravenous, infusion. A phase I and pharmacologic study. J Natl Cancer Inst. 1988;80:1039-44.

40. Ross R. Atherosclerosis--an inflammatory disease. $N$ Engl $J$ Med. 1999;340:115-26.

41. Ridker PM, Rifai N, Stampfer MJ, Hennekens CH. Plasma concentration of interleukin-6 and the risk of future myocardial infarction among apparently healthy men. Circulation. 2000;101:1767-72.

42. Ridker PM, Rifai N, Pfeffer M, Sacks F, Lepage S, Braunwald E. Elevation of tumor necrosis factoralpha and increased risk of recurrent coronary events after myocardial infarction. Circulation. 2000;101:2149-53.

43. Maes M, Meltzer HY. The serotonin hypothesis of major depression. New York: Raven Press; 1995.

44. Owens MJ, Nemeroff CB. Role of serotonin in the pathophysiology of depression: focus on the serotonin transporter. Clin Chem. 1994:40:288-95. 
45. Vikenes K, Farstad M, Nordrehaug JE. Serotonin is associated with coronary artery disease and cardiac events. Circulation. 1999;100:483-489.

46. Schini-Kerth VB, Fisslthaler B, Van Obberghen-Schilling E, Busse R. Serotonin stimulates the expression of thrombin receptors in cultured vascular smooth muscle cells. Role of protein kinase C and protein tyrosine kinases. Circulation. 1996;93:2170-7.

47. Strik JMH, Honig A, Lousberg R, Lousberg A, Cheriex EC. Tuynman-Qua H, Kuijpers PMJC, Wellens HJJ, Van Praag HM. Efficacy and safety of fluoxetine in the treatment of patients with major depression following first myocardial infaretion: findings from a double-blind placebocontrolled trial. Psychosomatic Medicine. 2000;62:783-789.

48. Glassman AH, O'Connor CM, Califf RM, Swedberg K, Schwartz P, Bigger JT, Jr., Krishnan KR, van Zyl LT, Swenson JR, Finkel MS, Landau C, Shapiro PA, Pepine CJ, Mardekian J, Harrison WM, Barton D, McLvor M. Sertraline treatment of major depression in patients with acute MI or unstable angina. JAMA. 2002;288:701-9.

49. Berkman LF, Blumenthal J, Burg M, Carney RM, Catellier D, Cowan MJ, Czajkowski SM, DeBusk R, Hosking J, Jaffe A, Kaufmann PG, Mitchell P, Norman J, Powell LH, Raczynski JM, Schneiderman N. Effects of treating depression and low perceived social support on clinical events after myocardial infarction: the Enhancing Recovery in Coronary Heart Disease Patients (ENRICHD) Randomized Trial. Jama. 2003;289:3106-16.

50. van den Brink RHS, van Melle J, Honig A, Schene AH, Crijns HJGM, Lambert FPG, Ormel J. Treatment of depression after myocardial infaretion and the effects on cardiac prognosis and quality of life: Rationale and outline of the Myocardial INfarction and Depression - Intervention Trial (MIND-IT). Am Heart J. 2002;144:219-225. 

Chapter 1

Polyunsaturated fatty acids: the missing link between cardiac events and depression?

Annique Schins, Adriaan Honig, Michael Maes Acta Neuropsych 2001,13: 38-45 
The relationship between myocardial infarction (MI), depression and cardiac death is not well understood. There is evidence that polyunsaturated fatty acid (PUFA) metabolism and composition in phospholipids and cholesterylesters are involved in the pathophysiology of affective disorders and cardiac dysregulation. In this paper the relationship of PUFAs with 1) cardiac events 2) depressive disorder and 3) the inflammatory response system (IRS) will be reviewed. The underlying pathophysiologic mechanisms relate to the effects of dietary fatty acids on the IRS, the HPA-axis, serotonin metabolism and platelet reactivity. These effects are the result of the important effects of PUFAs on the structure and function of localized membrane domains, their involvement in eicosanoid synthesis and their influence on intracellular signalling pathways and gene expression. Antidepressant treatment has been shown to have immunosuppressive effects in healthy volunteers. In patients with bipolar disorder or schizophrenia, PUFA supplementation resulted in significant symptom reduction. In the ongoing substudy of the MIND-IT, the effects of antidepressant treatment on immune status, PUFA composition in serum phospholipids and cholesterylesters and whole blood serotonin in depressive post-MI patients will be investigated. More knowledge on the relationships between PUFAs in diet, IRS parameters and serotonin metabolism may alter treatment strategies in the prevention of both cardiac death and the occurrence of depressive disorder in cardiac patients. 


\section{Introduction}

Depressive symptoms and a major depressive episode co-occurring with ischaemic heart disease have a major negative impact on cardiovascular prognosis; both conditions increase the morbidity and mortality four to five fold in the first 18 months post myocardial infaretion (MI) ${ }^{1.3}$. Therefore, mayor depression post-Ml has a similar survival impact as well as established risk factors, such as hypercholesterolemia. The most common cause of death in depressed post-MI patients is acute arrhythmia '. Hypothalamic-pituitary-adrenal axis (HPA-axis) hyperactivity, one of the hallmarks of major depressive disorders ${ }^{4}$, is accompanied by changes in the sympathetic nervous system tone, which results in a decreased heart rate variability (HRV), a risk factor for sudden cardiac death.

Depression is also a risk factor for the occurrence of $\mathrm{MI}$ in previously healthy subjects ${ }^{5-9}$, On the other hand, MI predisposes to depression as in the post-MI period the prevalence of major depression is about $13-20 \%{ }^{1-3}$, rising to $20-30 \%$ one year post $\mathrm{MI}^{10}$. The relationship between MI, affective dysregulation and cardiac death is as yet not well understood. There is evidence that alterations in the metabolism of fatty acids (FAs) and the composition of poly unsaturated fatty acids (PUFAs) in phospholipids and cholesterylesters are one of the mechanisms involved in the pathophysiology of affective disorder ${ }^{11-13}$ and of cardiac dysregulation ${ }^{14-16}$. In this paper a possible relationship between the above conditions is given, focussing on the role of PUFAs in MI and depression.

FAs can be classified in three families: saturated FAs, mono-unsaturated FAs (one double bond) and poly-unsaturated fatty acids (more double bonds). PUFAs are essential fatty acids since humans lack the desaturase enzyme, which inserts double bonds in the omega $(\omega)$ position of the fatty acid chain. PUFAs have important effects on the structure and physical properties of localized membrane domains and, in addition, are involved in eicosanoid synthesis (i.e. prostaglandins, thromboxane, prostacycline), signal transduction and the activation of nuclear transcription factors 17. Two classes of PUFA are the $\omega 6$ and $\omega 3$ PUFAs. Except for the brain and the retina, the plasma and other tissues contain more $\omega 6$ FA. Western diet contains 10- to 20- times more $\omega 6$ than $\omega 3$ PUFA $^{18} . \omega 6$ is present in vegetable oils; $\omega 3$ in a diet rich of cold water fish oils. Fish-related fatty acids appear to change the fatty acid composition of tissues to a much greater extent than might be 
expected from the actual percentage present in dietary fat. A deficiency of PUFAs dramatically alters the FA composition of various organ membranes, including those in the brain ${ }^{19,20}$. The blood brain barrier is one of the possible sites for elongation and desaturation of linoleic acid (LA, CI8:2 $\omega 6)$ and -more extensively- for $\alpha$-linolenic acid $(\alpha-\mathrm{LA}, \mathrm{C} 18: 3 \omega 3)^{2 \mathrm{I}}$. In the brain docosahexanoic acid (DHA, C22:6 $\omega 3$ ) is most abundant in membranes associated with synaptic function ${ }^{22}$. Steady state PUFA levels are a reflection of dietary intake, its metabolism and degradative processes.

\section{PUFA and depression}

As mentioned before, the relationship between coronary artery disease and depression is still unclear. Various types of relationships between the two disorders can be postulated.

First, a coincidental relationship. This option is not likely as the prevalence of depression in cardiovascular disease is at least four fold of what would be expected in the general population, as is increased cardiac death in depressed patients with coronary artery disease.

A second possible relationship is a causal one. Indeed, in prospective studies depression has been identified as an independent risk factor for the development of cardiovascular disease ${ }^{23-26}$. However depression may also co-occur with MI or develop in the post-MI period ${ }^{27}$, whereby depression is related to increased cardiac morbidity and mortality independent of known risk factors which might be related to negative mood driven behavior such as hypercholesterolemia, nicotine or physical activity. In post-MI depression no relationship between severity of MI and occurrence of depression has been found ${ }^{1-3,28-31}$. Intuitively one would expect a larger MI to result in more depressive symploms as a larger MI is generally accompanied by increased physical handicap and therefore a diminished quality of life. As this is clearly not the case, MI cannot be regarded as a mere psychological event triggering depression. A causal relationship between depression and MI is therefore unlikely. The relationship appears to be a common pathophysiological pathway. A growing body of evidence in both clinical and preclinical data is now available suggesting that immunological and PUFA related factors are involved.

There is substantial evidence that major depression is associated with $\omega 3$ depletion. In patients with a major depression a depletion of $\omega 3$ PUFAs in membrane phospholipids has been observed ${ }^{13}$. Adams et al. observed a significant positive relationship between the severity of depression in unmedicated patients and the ratio of arachidonic acid to eicosapentanoic acid (AA/EPA) in serum 
phospholipids and erythrocyte membranes ${ }^{32}$. Severity of depression correlated negatively with both $\omega 3$ PUFA content in red blood cell membrane and dietary intake of these PUFAs ${ }^{33}$. A significantly increased $\omega 6 / \omega 3$ PUFA ratio together with a significantly lower total $\omega 3$ PUFAs was found in major depressed patients compared to minor depressed and healthy controls ${ }^{11,12}$.

A deficiency of $\omega 3$ PUFAs in depressive disorder may have deleterious effects in an arrhythmia prone situation such as in the peri-MI period. A reduced heart rate variability (HRV), which reflects an increased predisposition for ventricular fibrillation, has been found in depressive patients compared with normal controls ${ }^{34.35}$ and in depressed coronary artery disease (CAD) patients when compared to non-depressed CAD patients ${ }^{36}$.

Many studies have addressed possible factors influencing serotonin turnover, availability and metabolism. The immune system appears to influence serotonin availability in the brain. Proinflammatory cytokines such as II-I and INF- $\alpha$ induce the enzyme indoleamine-2, 3 - dioxygenase (IDO), which converts the essential aminoacid tryptophan, the precursor of 5HT, to kynurenic acid and quinolinic acid ${ }^{37.38}$. Another factor influencing the metabolism of serotonin (5-HT) is membrane PUFA composition. In the brain dietary fatty acids, in particular PUFAs, modify membrane structure and function by changing the index of viscosity and fluidity and by modulating the activity of tryptophan hydroxylase, the rate-limiting enzyme in 5-HT synthesis. ${ }^{12.21 .39}$.

The relation between PUFA diet and serotonin turnover was suggested by the finding that among healthy volunteers, low levels of plasma docosahexanoic acid (DHA, C22:6 concentrations of cerebrospinal fluid 5-HIAA, a marker of brain serotonin turnover ${ }^{40}$. Animal studies have shown accumulation of brain tryptophan, followed by an increase of brain serotonin after feeding with $\omega 3$ PUFAs ${ }^{4 I}$. There are until now no data linking whole blood serotonin and PUFA status.

\section{PUFA and cardiac events}

A low rate of coronary heart disease (CHD) was reported in Eskimo populations and Japanese people. These populations appeared to consume a diet rich in fish oil ${ }^{42.44}$. Additionally an immunoregulatory effect of $\omega 3$ PUFAs was suggested because of a very low incidence of inflammatory and autoimmune disorders in populations such as Greenland Eskimos ${ }^{17,44}$. 
63. PUFAs have been shown to reduce the risk of primary cardiac arrest and sudden cardiac death 14-16. Results from experimental studies in animals suggest that intake of $\omega 3$ PUFAs, compared with saturated and mono unsaturated FAs, reduces vulnerability to ventricular fibrillation. ${ }^{45}$. In a population-based case-control study, intake of long-chain $\omega 3$ PUFAs was associated with a reduced risk of primary cardiac arrest in humans. The findings also showed that higher intakes (more than 1 2 fatty fish meal/week) were not associated with a further reduction in the risk of primary cardiac arrest $^{46}$.

Further evidence of the protective antiarrhythmic properties of $\omega 3$ PUFAs has been provided by the measurement of heart rate variability (HRV). Low HRV is a risk factor for sudden cardiac death 47,48 and reflects altered autonomic tone and electrical (un)stability of the myocardium. A reduced content of 103 PUFAs in platelet membranes of patients after myocardial infarction has been shown to be associated with a decreased $\mathrm{HRV}^{49}$. In addition, fish oil supplementation led to an increase in HRV in these patient $\mathrm{s}^{50}$.

In addition to increased vulnerability to arrhythmias, increased tendency for thrombotic events can compromise the post-MI patient. In major depression enhanced platelet activation and responsiveness has been observed ${ }^{51}$. Increased platelet reactivity was found in depressed patients with ischaemic heart disease (IHD) compared to non-depressed patients with IHD ${ }^{52,53}$.

In 63 supplementation studies, preclinical data show significant decreased platelet aggregation and thromboxane A2- a potent platelet aggregator and vasoconstrictor- production in $\omega 3$ PUFA fed rats $^{54,55}$. In humans a low intake of $\omega 3$ PUFAs in elderly people led to a significant decrease in systolic blood pressure and a trend towards decreased platelet aggregation and basal formation of thromboxane B2 ${ }^{56}$ : In conclusion, the tendency of platelets to aggregate in response to different agonists is significantly lowered after dietary intake of $\omega 3$ PUFA (for review see ${ }^{57}$ ).

\section{PUFA and the immune system}

Both depression and MI are accompanied by activation of the inflammatory response system (IRS). IRS activation is accompanied by signs of an acute phase (AP) response, increased secretion of proinflammatory cytokines ${ }^{58}$, lower zinc $(\mathrm{Zn})^{59}$ and increased secretion of prostaglandins in plasma ${ }^{60}$. On the basis of the hypothesis that arteriosclerosis fundamentally represents a chronic inflammatory 
disorder, several studies addressed the relationship between indices of immune activation and vascular risk. Increased levels of interleukin-6 (IL-6), tumor necrosis factor- $\alpha$ (TNF- $\alpha$ ) and acute phase proteins (APP) have been reported in acute myocardial infarction (AMI), unstable AP and are associated with increased risk of future $\mathrm{MI}^{61-63}$.

Cytokines and their receptors have been localized within the brain, acting as mediators between immune and nerve cells ${ }^{64}$. Several studies have investigated the possible role of cytokines in major psychiatric disorders. In major depression increases in the plasma concentration of IL-1 and IL-6 have been reported ${ }^{58,65-67}$. Most investigators confirm an increase in the plasma levels of acute phase proteins, notably haptoglobin ${ }^{68.69}$. One of the characteristics of an AP response is a fall in serum $\mathrm{Zn}$. In depressive patients serum $\mathrm{Zn}$ concentrations were found to be lower compared to normal controls and clinical improvement was accompanied by increments in serum $\mathrm{Zn}{ }^{70}$, Apart from the fact that serum $\mathrm{Zn}$ seems to be a good marker for the severity of depression, it is also a sensitive marker for immune activation ${ }^{59}$. Highly significant correlations between serum $\mathrm{Zn}$ and markers of IRS activation have been found, notably the inverse relationship between serum $\mathrm{Zn}$ and IL $-6^{12}$,

Immune activation has a number of consequences. First, cytokines such as IL-1 and IL-6 induce "sickness behavior", characterized by anorexia, weight loss, malaise, anhedonia and sleep disturbances, symptoms similar to those observed in major depression ${ }^{37}$. Second, preclinical data suggest that the immune response after induction of $\mathrm{Ml}$ in rats results in formation of immune complexes in serum. Extravasation of these complexes occur in distinct areas of the brain regulating mood and heart rate ${ }^{71,72}$. Injection of TNF- $\alpha$, a major pro-inflammatory cytokine, produces the same results. Subsequently it was suggested that MI-mediated IRS activation results in leakage of the blood-brain-barrier with damage in specific areas of the brain. Clinical results may be in support of these preclinical findings since in clinically depressed but physically healthy patients white matter hyperintensities and gray matter lesions have been described ${ }^{73}$ and post. MI depression is particularly related to fatal arrhythmia. Third, pro-inflammatory cytokines, such as IL-1 and IL-6, stimulate the activity of the hypothalamic-pituitary-adrenal-axis (HPA-axis) resulting in hypercortisolemia ${ }^{74}$ and changes in sympathetic nervous system tone. Four, pro-inflammatory cytokines, have major effects on the serotonergic (5HT) system which is involved in the pathophysiology of depression. IL-1 and interferon- $\alpha$ (INF- $\alpha$ ) induce the enzyme indoleamine-2,3dioxygenase (IDO), which converts the essential amino acid tryptophan, the precursor of 5HT, to 
kynurenic acid and quinolinic acid. This causes a depletion of plasma tryptophan and thereby a reduction of 5-HT synthesis in the brain ${ }^{37,38}$. A reduced availability of 5-HT facilitates the occurrence of both depressive symptomatology and occlusion of coronary arteries via serotonin regulated platelet aggregation and coronary artery constriction ${ }^{75}$.

(03 PUFAs appear to have anti-inflammatory and immunoregulatory effects. This is also suggested by the low incidence of inflammatory and autoimmune disorders in the Eskimo populations. $\omega 6$ PUFAs are precursors of prostaglandin E2; $\omega 3$ PUFAs on the other hand have an inhibitory effect on prostaglandin E2 production (a pro-inflammatory regulator of the development and function of $\mathrm{T}$ and B lymphocytes) ${ }^{17}$. Increased $\omega 3$ PUFA dietary intake sharply reduces the production of proinflammatory cytokines (IL-1, IL-6, TNF- $\alpha$ ), diminishes lymphocyte proliferation, T-cell-mediated cytotoxicity, natural killer cell activity, macrophage-mediated cytotoxicity, monocyte and neutrophil chemotaxis and adhesion molecule expression ${ }^{76,77}$. Another mechanism through which (6) PUFAs may exert their effect is by modulating intra-cellular signalling pathways and gene expression within inflammatory and immune cells ${ }^{17,77}$. 
Figure 1 : Encets of Jielary faty acids on biological parameters and associted elinical discases.

\section{Pathophysiological mechanisms}

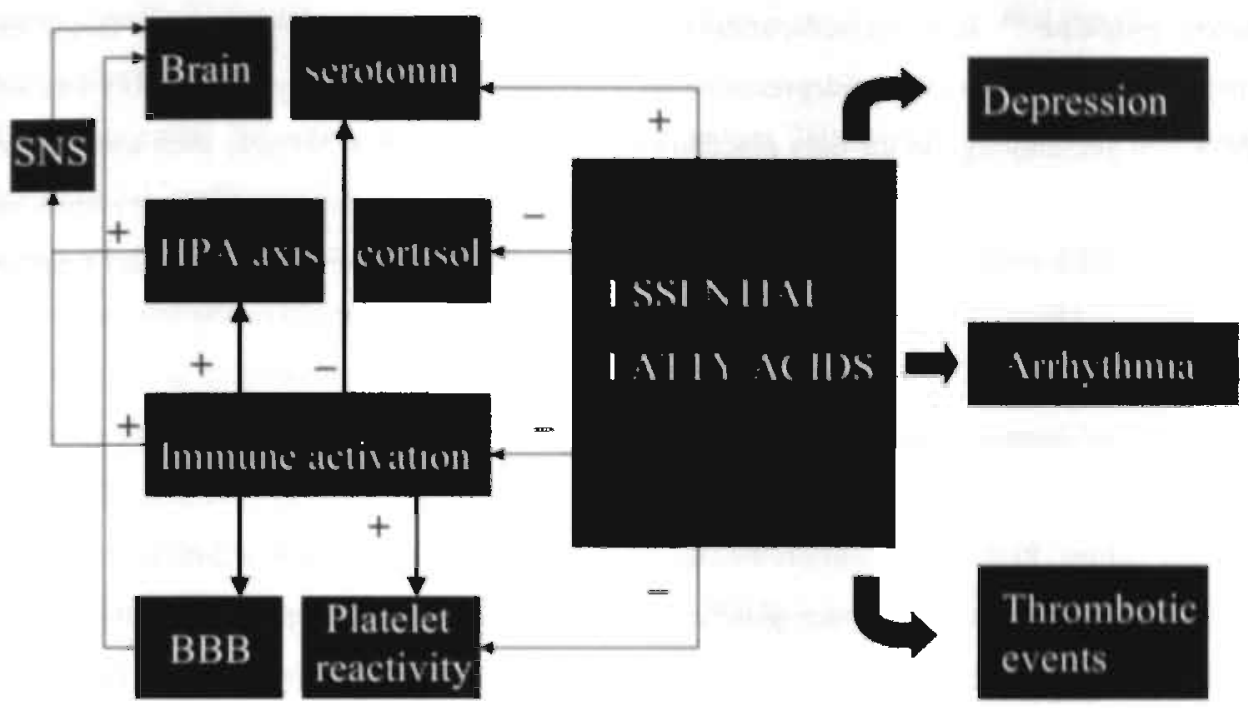

SNS = sympathetic nervous system, BBB = blood-brain-barrier, HPA-axis = hypothalamic- pituitary-adrenal axis 


\section{Antidepressant treatment}

Apart from effects on the serotonergic and neuro-adrenergic system, selective serotonin reuptake inhibitors (SSRIs) and tricyclic antidepressants (TCAs) have anti-inflammatory properties, both in preclinical ${ }^{78}$ and in clinical studies ${ }^{37}$. These drugs suppress the plasma concentrations of AP proteins and the production of pro-inflammatory cytokines, while increasing that of IL-10, an antiinflammatory cytokine ${ }^{37}$. In depressed patients antidepressants normalize HRV a risk factor for cardiac mortality ${ }^{79}$. An effect of antidepressants on the reduction in morbidity or mortality has not been established yet, although in the only placebo controlled study a trend towards such a reduction in cardiac morbidity in the SSRI group was found ${ }^{80}$. Only limited data concerning effects of antidepressant treatment on FA compositions have been published ${ }^{11,12}$ with no significant relation towards alteration of FA status.

\section{PUFA intervention studies}

As mentioned before, PUFA intervention studies have shown to reduce sudden cardiac death and primary cardiac arrest ${ }^{14-16}$, to decrease platelet activation and immune response and to increase HRY, Recently in a double blind placebo-controlled trial adjunctive therapy with $\omega 3$ PUFAs in patients with bipolar disorder resulted in significant symptom reduction and a significantly longer period of remission. Although the study was not designed to provide definitive data on antidepressant effects of 03 PUFA, treatment failures due to depressive exacerbations or recurrence occurred in the placebo group only ${ }^{81}$. The results from supplementation studies in patients with schizophrenia show above all improvement in the negative symptoms of schizophrenia ${ }^{82}$.

\section{Conclusion}

In literature there is evidence that 03 PUFA deficiency is involved in the pathophysiology of both myocardial infarction and depression. $\omega 3$ PUFA depletion is associated with 1) occurrence of depression and the severity of depression 2) higher incidence of CAD when compared to populations with a high $\omega 3$ PUFA diet 3) increased vulnerability for cardiac arrhythmias, and hence higher mortality rates in the post-MI period 4) increased activation of the IRS, leading to increased risk for future MI and depression in patients with a myocardial infarction. In addition, $\omega 3$ 
PUFA supplementation studies support an antithrombotic effect of the long chain essential FAs and an increase in central serotonin availability.

Until now, studies have assessed the immunological and fatty acid status in post-MI patients on the one hand and depressive patients on the other. In cardiac compromised patients supplemental studies with PUFAs have been done, but no data are available in depressed patients or in patients who have the combination of coronary artery disease and depressive disorder. Even less is known about the effect of antidepressant medication on immunological and fatty acid status: such a study is now underway.

The Myocardial Infaretion and Depression Intervention Trial (MIND-IT study) is a prospective longitudinal multicenter study in the Netherlands, which investigates whether antidepressant treatment can improve cardiac prognosis of patients with a depressive disorder following a MI. Moreover immune activation, fatty acid composition and blood serotonin levels will be assessed on two time point in patients with post-MI depression to test the hypothesis that post-MI depression is accompanied by 1) a decrease of total $\omega 3$ PUFA and an increase of $\omega 6 / 03$ PUFA-ratio 2) an increase in IRS activation 3) a decrease of serum serotonin levels and 4) that successful treatment of depression after $\mathrm{MI}$ is reflected by a change in abovementioned parameters.

Further knowledge on the relationships between PUFA in diet, immune parameters and serotonin may alter treatment strategies in the prevention of both cardiac events and the occurrence of depressive disorder in cardiac patients. 


\section{References}

1. Frasure-Smith N, Lesperance F, Talajic M. Depression following myocardial infarction: impact on 6months survival. JAMA. 1993;270:1819-1825.

2. Frasure-Smith N, Lesperance F, Talajic M. Depression and 18 months prognosis after myocardial infarction. Circulation. 1995;91:999-1005.

3. Ladwig KH, Roll G, Breithardt G, Budde T, Borggrefe M. Post infarct depression and incomplete recovery 6 months after acute myocardial infarction. The Lancet. 1994;343:20-23.

4. Heuser I. The hypothalamic-pituitary-adrenal system in depression. Pharmacopsychiatry. 1998;31:10-13.

5. Anda R, Williamson D, Jones D, Macera C, Eaker E, Glassman A, Marks J. Depressed affect, hopelessness, and the risk of ischemic heart disease in a cohort of U.S. adults [see comments]. Epidemiology. 1993;4:285-94.

6. Wulsin LR, Vaillant GE, Wells VE. A systematic review of the mortality of depression. Psychosomatic Medicine. 1999;61:6-17.

7. Whooley MA, Browner WS. Association between depressive symptoms and mortality in older women. Study of Osteoporotic Fractures Research Group. Archives of Internal Medicine. 1998:159:2129-35.

8. Ferketich AK, Schwartzbaum JA, Frid DJ, Moeschberger ML. Depression as an antecedent to heart disease among women and men in the NHANES I study. National Health and Nutrition Examination Survey. Arch Intern Med. 2000;160:1261-8.

9. Ariyo AA, Haan M, Tangen CM, Rutledge JC, Cushman M, Dobs A, Furberg CD. Depressive symptoms and risks of coronary heart disease and mortality in elderly Americans. Circulation. 2000;102:1773-9.

10. Honig A, Lousberg R, Wojchiechowski F, Cheriex EC, Wellens H, Van Praag HM. Depression following a first myocardial infarction; similarities with and difference from 'ordinary' depression (Depressie na een eerste hartinfaret: overeenkomsten en verschillen met een gewone depressie). Ned Tijdschr Geneeskunde. 1997;141:196-199.

11. Maes M, Smith R, Christophe A, Cosyns P, Desnyder R, Meltzer H. Fatty acid composition in major depression: decreased $\mathrm{n} 3$ fractions in cholesteryl esters and increased $\mathrm{C} 20: 4 \mathrm{n} 6 / \mathrm{C} 20: 5 \mathrm{n} 3$ ratio in cholesteryl esters and phospholipids. J Affect Dis. 1996;38:35-46.

12. Maes M, Christophe A, Delanghe J, Altamura C, Neels H, Meltzer H. Lowered n3 polyunsaturated fatty acids in serum phospholipids and cholesteryl esters of depressed patients. Psychiatry Res. 1999:85:275-291.

13. Peet M, Murphy B, Shay J, Horrobin D. Depletion of omega-3 fatty acid levels in red blood cell membranes of depressive patients. Biol Psychiatry. 1998;43:315-9.

14. Albert CM, Hennekens CH. ODonnel CJ, Ajani UA, Careỹ VJ, Willet WC, Ruskin JN. Fish consumption and risk of cardiac death. JAMA. 1998;279:23-28.

15. Siscovick DS, Raghunathan TE, King I, Weinmann S, Wicklund KG, Albright J, Bovbjerg V, Arbogast P. Smith H, Kushi LH, Cobb. LA, Copass MK, Psaty BM, Lemaitre R, Retzlaff B, Childs M. Knopp RH. Dietary intake and cell membrane levels of long chain n-3 polyunsaturated fatty acid and the risk of primary cardiac arrest. JAMA. 1995;274:1363-1367.

16. Burr ML, Fehily AM, Gilbert JF, Rofers S. Holliday RM, Sweetnam PM, Elwood PC, Deadman NM. Effects of changes in fat, fish and fibre intakes on death in myocardial reinfarction; diet and reinfarction trial. Lancet, 1989:2:757-761.

17. Calder PC. Dietary fatty acids and the immune system. Lipids. 1999:34:S137-40.

18. Spector AA. Essentiality of fatty acids. Lipids. 1999;34:S1-3.

19. Bourre JM, Dumont O, Durand G. Brain phospholipids as dietary source of (n-3) polyunsaturated fatty acids for nervous tissue in the rat. $J$ Neurochem. 1993;60:2018-28.

20. Bourre JM, Bonneil M, Clement M, Dumont O, Durand G, Lafont H, Nalbone G, Piciotti M. Function of dietary polyunsaturated fatty acids in the nervous system. Prostaglandins Leukot Essent Fatty Acids, 1993;48:5-15, 
21. Yehuda S, Rabinovitz S, Mostofsky DI. Essential fatty acids are mediators of brain biochemistry and cognitive functions. $J$ Neurosci Res. 1999;56:565-70.

22. Fernstrom JD. Can nutrient supplements modify brain function? Am J Clin Nutr. 2000;71:16698$75 \mathrm{~S}$.

23. Aromaa A, Raitasalo R, Reunanen A, Impivaara O, pukkala E, Tuomilehto J, Salonen JT. Depression and cardiovascular diseases. Acta Scandinavica Psychiatrica. 1994;(Suppl.) 377:77-82.

24. Pratt LA, Ford DE, Crum RM, Armenian HK, Gallo JJ, Eaton WW. Depression, psychotropic medication, and risk of myocardial infaretion: prospective data from the Baltimore ECA follow-up. Circulation. 1996;94:3123-3129.

25. Barefoot JC, Schroll M. Symtomps of depression, acute myocardial infaretion, and total mortality in a community sample. Circulation. 1996:93:1976-1980.

26. Ford DE, Mead LA, Chang PP, Cooper-Patrick L, Wang N-Y, Klag MJ. Depression is a risk factor for coronary artery disease in men. Archives of internal medicine. 1998;158:1422-1426.

27. Lesperance F, Frasure-Smith N, Talajic M. Major depression before and after myocardial infarction: its nature and consequences. Psychosomatic Medicine. 1996;58:99-110.

28. Ladwig KH, Kieser M, Konig J, Breithardt G, Borggrefe M. Affective disorders and survival after acute myocardial infarction (results from the post-infarction late potential study). Eur Heart $J$. 1991:12:959-964.

29. Ahern DK, Gorkin L, Anderson R, Tierney C, Hallstrom A, Ewart C, Capone RJ, Schron E, Kornfeld D, Herd JA. Biobehavioral variables and mortality on cardiac arrest in the Cardiac Arrhythmia pilot study (CAPS). American Journal of Candiology. 1990;66:59-62.

30. Havik. OE, Maeland JG. Patterns of emotional reactions after a myocardial infaretion. Journal of Psychosomatic Research. 1990;34:271-285.

31. Forrester AW, Lipsey JR, Teitelbaum ML, DePaulo JR, Andrzejeweski PL. Depression following myocardial infarction. Int J Psychiatry Med. 1992:22:33-46.

32. Adams PB, Lawson S, Sanigorski A, Sinclair AJ. Arachidonic acid to eicosapentaenoic acid ratio in blood correlates positively with clinical symptoms of depression. Lipids, 1996;31 (Suppl):S157-61.

33. Edwards R, Peet M. Shay J, Horrobin D. Omega-3 polyunsaturated fatty acid levels in the diet and in red blood cell membranes of depressed patients. Journal of Affective Disorders. 1998:48:149-155.

34. Dalack GW, Roose SP. Perspectives on the relationship between cardiovascular disease and affective disorder. J Clinical Psychiatry. 1990;51 (Suppl.):4-9.

35. Rechlin T, Weis M, Spitzer A, Kaschka WP. Are affective disorders associated with alterations of heart rate variability? If Affect Disord. 1994:32:271-5.

36. Carney RM, Saunders RD, Freedland KE, Stein P, Rich MW, Jaffe AS. Association of depression with reduced heart rate variability in coronary artery disease. American Journal of Cardiology, 1995;76:562-564.

37. Maes M. Major depression and activation of the inflammatory system. New York: Kluwer Academic/Plenum Press: 1999.

38. Zalcman S, Green-Johnson JM, Murray L, Nance DM, Dyck D, Anisman H, Greenberg AH. Cytokine-specific central monoamine alterations induced by interleukine-1, -2, and -6, Brain Research. 1994:643:40-49.

39. Block. ER, Edwards D. Effect of plasma membrane fluidity on serotonin transport by endothelial cells. Am J Physiol. 1987;253:C672-8.

40. Hibbeln JR. Fish consumption and major depression [letter] [see comments]. Lancet. 1998;351:1213.

41. Yokogoshi H. Kimiko O, Okitsu M. Accumulation of brain tryptophan in rats after administering various fats or fatty acids. Biosci Biotech Biochem. 1993:57:181-4.

42. Bang HO, Dyerberg J, Hjoorne N. The composition of food consumed by Greenland Eskimos. Acta Med Scand. 1976;200:69-73.

43. Kromhout. D, Bosschieter EB, de Lezenne Coulander C. The inverse relation between fish. consumption and 20-year mortality from coronary heart disease. N Engl J Med. 1985;312:1205-9.

44. Simopoulos AP. Omega-3 fatty acids in health and disease and in growth and development [see comments]. Am J Clin Nutr. 1991:54:438-63. 
45. Kang JX, Leaf A. Antiarrhythmic effects of polyunsaturated fatty acids. Circulation. 1996;94:1774 1780.

46. Siscovick DS, Raghunathan T, King I, Weinmann S, Bovbjerg VE, Kushi L, Cobb LA, Copass MK, Psaty BM, Lemaitre R, Retzlaff B, Knopp RH. Dietary intake of long-chain n-3 polyunsaturated. fatty acids and the risk of primary cardiac arrest. Am J Clin Nutr. 2000;71:208S-12S.

47. Kleiger RE, Miller JP, Bigger JT, Jr., Moss AJ. Decreased heart rate variability and its association with increased mortality after acute myocardial infarction. Am J Cardiol, 1987;59:256-62.

48. Carney RM, Freedland KE, Veith RC, Jaffe AS, Can treating depression reduce mortality after an acute myocardial infarction? Psychosomatic Medicine. 1999;61:666-675.

49. Christensen. JH, Korup E, Aaroe J, Tort E, Moller J, Rasmussen K, Dyerberg J, Schmidt EB. Fish consumption, n-3 fatty acids in cell membranes, and heart rate variability in survivors of myocardial infarction with left ventricular dysfunction. American Journal of Cardiology. 1997:79:1670-1673.

50. Christensen JH, Gustenhoff P, Korup E, Aaroe J, Toft E, Moller J, Rasmussen K. Effect of fish oil on heart rate variability in survivors of myocardial infarction: a double-blind randomised controlled trial. BMJ. 1996:312:677-678.

51. Musselman DL, Tomer A, Manatunga AK, Knight BT, Porter MR, Kasey S, Marzec U, Harker LA, Nemeroff CB. Exaggerated platelet reactivity in major depression. Am J Psychiatry. 1996;153:13131317.

52. Laghrissi-Thode F, Wagner WR, Pollock BG, Johnson PC, Finkel MS. Elevated platelet factor 4 and beta-thromboglobulin plasma levels in depressed patients with ischemic heart disease. Biol Psychiatry. 1997:42:290-295.

53. Kuijpers PMJC, Hamulyak K, Strik JMH, Wellens HJJ, Honig A. Beta-thromboglobulin and platelet factor 4 levels in post myocardial infarction patients with major depression. Psychiatry Res. 2002;109:207-210.

54. Yamada N, Shimizu J, Wada M, Takita T, Innami S. Changes in platelet aggregation and lipid metabolism in rats given dietary lipids containing different n-3 polyunsaturated fatty acids. Journal of mutritional science and vitaminology. 1998:44:279-89.

55. Ikeda I, Yoshida H. Tomooka M, Yosef A, Imaizumi K, Tsuji H, Seto A. Effects of long-term feeding of marine oils with different positional distribution of eicosapentaenoic docosahexaenoic acids on lipid metabolism, eicosanoid production, and platelet aggregation in hypercholesterolemic rats. Lipids. 1998;33:897-904.

56. Vericel E, Calzada C, Chapuy P, Lagarde M. The influence of low intake of $\mathrm{n}-3$ fatty acids on platelets in elderly people. Atherosclerosis. 1999;147:187-92.

57. Malle E, Kostner GM. Effects of fish oils on lipid variables and platelet function indices. Prostaglandins Leukot Essent Fatty Acids. 1993:49:645-663.

58. Maes M. Bosmans E, De Jongh R, Kenis G, Vandoolaeghe E, Neels H. Increased serum IL-6 and IL1 receptor antagonist concentrations in major depression and treatment resistant depression. Cytokine. 1997:9:853-8.

59. Maes M, Vandoolaeghe E, Neels H, Demedts P, Wauters A, Meltzer HY, Altamura C, Desnyder R. Lower serum zinc in major depression is a sensitive marker of treatment resistance and of the immune/inflammatory response in that iliness. Biol Psychiatry. 1997:42:349-58.

60. Calabrese JR, Skwerer RG. Barna B, Gulledge AD, Valenzuela R, Butkus A, Subichin S, Krupp NE. Depression, immunocompetence, and prostaglandins of the E series. Psychiatry Res. 1986;17:41-7.

61. Ueda K, Takahashi M, Ozawa K, Kinoshita M. Decreased soluble interleukin-6 receptor in patients with acute myocardial infarction. Am Heart J. 1999;138:908-15.

62. Ridker PM, Rifai N, Pfeffer M, Sacks F, Lepage S, Braunwald E. Elevation of tumor necrosis factoralpha and increased risk of recurrent coronary events after myocardial infarction. Circulation. 2000:101:2149-53.

63. Ridker PM, Rifai N, Stampfer MJ, Hennekens CH. Plasma concentration of interleukin-6 and the risk of future myocardial infaretion among apparently healthy men. Circulation. 2000;101:1767-72.

64. Connor TJ, Leonard BE. Depression, stress and immunological activation: the role of cytokines in depressive disorders. Life sciences. 1998;62:583-606. 
65. Sluzewska A, Rybakowski J, Bosmans E. Indicators of immune activation in major depression. Psychiatry Research. 1996;64:161-167.

66. Maes M, Vandoolaeghe E, Ranjan R, Bosmans E, Bergmans R, Desneyder R. Increased serum interleukin-1-receptor-antagonist concentrations in major depression. Journal of Affective Disonders. 1995;36:29-36.

67. Maes M, Meltzer HY, Bosmans E, Bergmans R, Vandoolaeghe E, Ranjan R, Desneyder R. Increased plasma concentrations of interleukin-6, soluble interleukin-6 receptor, soluble interleukin-2 and transferrin receptor in major depression. Journal of Affective Disorders. 1995;34:301-309.

68. Maes M, Scharpe S, Meltzer HY, Cosyns P. Relationships between increased haptoglobin plasma levels and activation of cell-mediated immunity in depression. Biol Psychiatry, 1993;34:690-701.

69. Maes M, Scharpe S, Van Grootel L, Uyttenbroeke W, Cooreman W, Cosyns P, Suy E. Higher alfa 1antitrypsin, haptoglobin, ceruloplasmin and lower retinol binding protein plasma levels during depression: further evidence for the existence of an inflammatory response during that illness. Journal of Affective Disorders. 1992;24:183-192.

70. McLoughlin IJ, Hodge JS. Zinc in depressive disorder. Acta Psychiatr Scand. 1990;82:451-3.

71. Ter Horst GJ. Emotions and the heart. Acta Neuropsychiatrica. 1998;10:44-50.

72. Ter Horst GJ. TNF-alpha-induced selective endothelial leakage and increased mortality risk in postmyocardial infarction depression (letter). American Journal of physiology, 1998;275:H19101911.

73. Lenze E, Cross D, McKeel D, Neuman RJ, Sheline YI. White matter hyperintensities and gray matter lesions in physically healthy depressed subjects. Am J Psychiatry. 1999;156:1602-7.

74. MeCann SM, Lyson K, Karanth S, Yimeno M, Belova N, Kamat A, Rettori V. Role of cytokines in the endocrine system. Ann N Y Acad Sci. 1994;741:50-63.

75. Cerrito F, Lazzaro MP, Gaudio E, Arminio P, Aloisi G. 5HT2-receptors and serotonin release: their role in human platelet aggregation. Life Sci. 1993:53:209-15.

76. Meydani SN, Lichtenstein AH, Cornwall S, Meydani M, Goldin BR, Rasmussen H, Dinarello CA, Schaeffer EJ. Immunologic effects of national cholesterol education panel step-2 diets with and without fish-derived N-3 fatty acid enrichment. J Clin Invest. 1993;92:105-13.

77. Calder PC. Immunoregulatory and anti-inflammatory effects of n-3 polyunsaturated fatty acids. Braz $J$ Med Biol Res. 1998;31:467-90.

78. Suzuki E, Shintani F, Kanba S, Asai M, Nakaki T. Induction of interleukin-1 beta and interleukin -1 receptor antagonist in RNA by chronic treatment with various psychotropics in widespread area of rat brain. Neuroscience Letters. 1996;215:201-204.

79. Balogh S, Fitzpatrick DF, Hendricks SE, Paige SR. Increases in heart rate variability with successful treatment in patients with major depressive disorder. Psychopharmacol Bull. 1993;29:201-6.

80. Strik JJMH, Honig A, Lousberg R, Lousberg A, Cheriex EC, Tuynman-Qua H, Kuijpers PMJC, Wellens HJJ, Van Praag HM. Efficacy and safety of fluoxetine in the treatment of patients with major depression following first myocardial infarction: findings from a double-blind placebocontrolled trial. Psychosomatic Medicine. 2000;62:783-789.

81. Stoll AL, Severus WE, Freeman MP, Rueter S, Zboyan HA, Diamond E, Cress KK, Marangell LB. Omega 3 fatty acids in bipolar disorder: a preliminary double-blind, placebo-controlled trial [see comments]. Arch Gen Psychiarry. 1999;56:407-12.

82. Maidment ID. Are fish oils an effective therapy in mental illness--an analysis of the data [In Process Citation]. Acta Psychiatr Scand. 2000;102:3-11. 



\section{PART I}

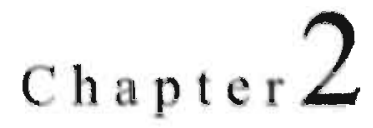

\section{Altered omega- 3 polyunsaturated fatty acid status in depressed post myocardial infarction patients.}

Annique Schins, Harry Crijns, Robert-Jan Brummer, Richel Lousberg. Michael Maes, Sigrid Celis, Adriaan Honig. 


\section{Abstract}

Background: Depression after myocardial infarction (MI) has been associated with increased cardiac morbidity and mortality due to increased risk of arrhythmia. Lower levels of long chain omega- 3 polyunsaturated fatty acids ( $\mathrm{n}-3$ LCPUFAs) have been found in somatically healthy individuals with depression and have also been associated with arrhythmia independent of depressive state. Both MI and depression have also been associated with inflammation.

Objectives: The goal of this study was to investigate 1) whether patients who develop depression post-MI, have higher arachidonic acid/ eicosapentanoic acid (AA/EPA) ratios than non-depressed post-MI patients 2) whether depressed post-MI patients have signs. of increased inflammation as measured by serum zinc and C-reactive protein (CRP) levels and 3) if treatment with the antidepressant mirtazapine influences PUFA. state.

Methods: A group of 29 patients with a diagnosis of depression post-MI were asked for blood collection before start as well as after 8 weeks treatment with mirtazapine or placebo. The control group ( $\mathrm{n}=21$ ) consisted of non-depressed post-MI patients, matched for age, gender and time elapsed since MI.

Results: Compared with the non-depressed group, depressed post-MI patients had significantly higher AA/EPA ratios ( $\mathrm{p}-0.042)$, indicating an unfavourable PUFA profile. The effect remained significant after controlling for potential confounders. Zinc and CRP levels did not differ significantly between the depressed and non-depressed group. Treatment with mirtazapine was associated with reduction of AA/EPA ratios.

Conclusions: The data give support to the hypothesis that depression in the post-MI period is associated with higher AA/EPA ratios. 


\section{Introduction}

Depression after MI is associated with increased cardiac morbidity and mortality ${ }^{1,2}$. Regarding the link between PUFA levels and coronary artery disease (CAD), both epidemiological studies ${ }^{3,4}$ and recent clinical cardiovascular trials ${ }^{5-7}$ have shown a negative association of $n-3$ PUFAs and cardiac death after MI. The reduction in mortality resulted predominantly from a reduction in arrhythmic deaths ${ }^{8}$. The mechanism by which n-3 PUFAs act to prevent fatal arrhythmias is based on the observation that n-3 PUFAs act on ion channel's in the cardiomyocyte, causing an alteration in the action potential that reduces myocardial vulnerability to ventricular fibrillation 9

Regarding depression and PUFAs, epidemiological data point towards higher prevalence of major depression among populations with low n-3 PUFA intake, defined as infrequent fish consumers ${ }^{10-}$ 12. Depletion of n-3 LCPUFAs and a higher AA/EPA ratio was reported in several cross-sectional studies comparing depressed patients with healthy controls ${ }^{13-17}$. Mechanisms have been postulated by which n-3 LCPUFAs may influence the neurobiology of depression. These include 1) increase of serotonin mediated neurotransmission 2) decrease of immune activation and 3) decrease of activation of the hypothalamic-pituitary-adrenal (HPA) axis ${ }^{18}$.

Both CAD and depression have also been linked to increased levels of inflammatory markers. Inflammatory markers such as CRP and interleukin-6 (II-6) have been associated with increased risk of vascular events rates ${ }^{19.20}$ and increased plasma levels of CRP and II- $6^{21-23}$ have also been found in somatically healthy patients with depression. Another marker of inflammation is total serum Zinc ( $\mathrm{Zn})$. In somatically healthy depressive patients, serum $\mathrm{Zn}$ concentrations were found fo be lower compared to normal controls (indicating inflammation) and clinical improvement was accompanied by increments in serum $\mathrm{Zn}^{24,25}$.

So far, studies have been looking at PUFA status either in patients with MI or somatically healthy depressed patients. The goal of this study was threefold. First, to investigate whether depressed post-MI patients have higher AA/EPA ratios than non-depressed post-MI patients. Secondly, whether depressed post-MI patients have lower serum $\mathrm{Zn}$ and higher serum CRP levels indicating inflammation, and thirdly, whether treatment with a noradrenergic and specific serotonergic antidepressant (NaSSA) mirtazapine has an effect on PUFA status.

\section{Patients and methods}

A consecutive cohort of 29 depressed MI patients, included in a randomised placebo controlled trial with mirtazapine (as part of their participation in the Myocardial Infarction and Depression - 
Intervention Trial) ${ }^{26}$ were asked for blood collection. MI diagnoses were made by a cardiologist and were based on to the following criteria: clinical presentation, electrocardiographic signs typical of an acute MI and enzyme aspartate aminotransferase (ASAT) levels of $\geq 80 \mathrm{U} /$ (twice the upper limit of normal). Depression was defined as meeting DSM-IV criteria for major or minor depression. Patients were diagnosed with a depressive disorder following a structured Composite International' Diagnostic Interview (CIDI-auto) done by a research assistant as well as a clinical interview by a psychiatrist. As part of their participation in the MIND-IT study, patients could not be included earlier than 3 months after MI. Intervention as part of the MIND-IT study, consisted of double blind treatment with placebo or mirtazapine (30-45 mg), an $\alpha_{2}$-adrenoreceptor antagonist, which also blocks $5-\mathrm{HT}_{2}, 5-\mathrm{HT}_{3}$ and $\mathrm{H}_{1}$ receptors ${ }^{27}$. Because of logistic reasons, the control subjects consisted of 21 non-depressed post-MI patients matched for age, gender and period elapsed since MI. Patients with diabetes mellitus and patients receiving anticoagulant medication except aspirin were excluded in this substudy. The study design was approved by the local ethical committee. All participants were fully informed and gave their written informed consent.

Sampling: Blood samples were taken between 9.00 and 11.00 a.m. after an overnight fast. A venipuncture was performed in the antecubital vein. Blood samples were collected and stored in sterile Vacutainer tubes without additives (Becton-Dickinson, Basel, Swiss) and samples centrifuged at $2200 \mathrm{~g}$ for 5 minutes. Serum samples were stored at $-70^{\circ}$ until analysis.

\section{Laboratory analysis}

A single operator carried out all assays of serum fatty acids at the same time, using the same batch of reagents. The fatty acid composition was measured by gas chromatography and expressed as a percentage of total fatty acid content in phospholipids. Serum $\mathrm{Zn}$ was determined on a Perkin-Elmer Analyst 800 atomic absorption spectrometer using an air-acetylene burner system. CRP was measured using a highly sensitive ELISA kit (ICN Pharmaceuticals, Orangeburg, NY, USA).

\section{Statistical Analysis}

First, baseline characteristics were investigated of the depressed and the non-depressed groups. Chisquare in case of dichotomous variables and t-test in case of continuous variables were applied. Next, multivariate linear regression analyses were performed to evaluate the association between 1) post-MI depression and PUFA status and 2) post-MI depression and inflammatory markers. Regression models were performed with $\mathrm{AA} / \mathrm{EPA}$ ratio, CRP and zinc as dependent variables and post-MI depression (0-1) as predictor. Traditional cardiovascular risk factors such as smoking, 
body mass index (BMI), hypertension, positive family history for CAD and cholesterol plasma levels and other possible confounders such as age, previous depressive episodes, extension of vessel disease (1, 2 or three), ace-inhibitor use and calcium channel blocker use, were tested for their potential confounding effects. Cook's distance was used to identify influential cases according to the lines described by Hair et al. ${ }^{28}$. The significance level was set at $\alpha=0.05$ (two-tailed). Statistical analyses were performed with SPSS 10.0 for Windows.

\section{Demographic data}

Patients' ages ranged from 38 to 81 (mean 55.5) in the group with a depressive disorder post-Mi and from 34 to 76 (mean 54.4) in the post-MI group without depression. The difference was not significant $(t=-0.4 ; p=0.69)$ (Table 1). Patients were diagnosed and started treatment for depression not before 3 months post-MI, and not later than 12 months post-Ml (mean 5.7 ; s.d.2.5). There were no significant differences between the groups with regard to $\mathrm{BMI}(\mathrm{t}=0.3 ; \mathrm{p}=0.74)$ or cholesterol plasma levels $(t=0.2 ; p=0.82)$. In the depressed group $65 \%$ smoked at the time of their infarction; $34 \%$ subsequently stopped smoking and at the time of blood sampling $31 \%$ continued smoking. In the non-depressed group $71 \%$ were smokers when admitted to the hospital, $52 \%$. stopped smoking and at sampling 19\% continued smoking. The differences were not statistically different. Other conventional risk factors for CAD such as hypertension and CAD in the family, were not significantly different between the groups. Infarction size, as measured by left ventricle ejection fraction (LVEF), creatinine kinase (CK) and enzyme aspartate aminotransferase (ASAT) levels, were not statistically different between the groups. Treatment of MI, defined as thrombolysis, percutaneous transluminal coronary angioplasty (PTCA) or coronary artery bypass. grafting (CABG), wạ also not statistically different between the groups. A positive family history for psychiatric diseases was not different between the groups, but the presence of previous. depression was significantly higher in the depressed group as compared to the non-depressed group. $\left(\chi^{2}=12.5 ; p<0.001\right)$. Mean BDI score of depressed patients was 14 (s.d. 8.0) and of non-depressed patients 3.48 (s.d. 2.7); the difference was significant $(p<0.001)$. Nearly all patients were prescribed aspirin (>93\%), a beta-blocker $(>81 \%)$ and a statin ( $>93 \%$ ). Prescription of ace-inhibitors (ACEI) was higher in the non-depressed group as compared to the depressed group ( $38 \%$ versus $21 \%)$, but the difference was not significant $(\mathrm{p}=0.13)$. Prescription of calcium channel blockers $(\mathrm{CCB})$ was. also not significant between the groups ( 19 and $17 \%$ respectively, $\mathrm{p}=0.93$ ). 
Table 1. Demographic and cardiovascular characteristics of non-depressed and depressed post-MI patients at baseline and at sampling.

\begin{tabular}{|c|c|c|c|}
\hline & $\begin{array}{c}\text { Non-depressed } \\
\text { MI-patients } \\
n=21\end{array}$ & $\begin{array}{c}\text { Depressed } \\
\text { MI-patients } \\
n=29\end{array}$ & p-value \\
\hline \multicolumn{4}{|l|}{ At baseline } \\
\hline Gender $(m / f)$ & $19 / 2$ & $26 / 3$ & NS \\
\hline Age & $54.4(10.6)$ & $55.5(10.0)$ & NS \\
\hline BMI & $27.1(3.6)$ & $26.8(4.2)$ & NS \\
\hline LVEF & $54.9(11.7)$ & $54.7(9.4)$ & NS \\
\hline $\mathrm{CK}_{\max }(\mathrm{U} / \mathrm{I})$ & $2197.9(1968.9)$ & $1906.8(1488.8)$ & NS \\
\hline $\mathrm{ASAT}_{\max }(\mathrm{U} / \mathrm{I})$ & $236.2(146.6)$ & $220.2(157.1)$ & NS \\
\hline Cholesterol (mg/dL) & $213.4(45.2)$ & $210.8(36.9)$ & NS \\
\hline trombolysis & $57.1 \%$ & $48.3 \%$ & NS \\
\hline PTCA & $33.3 \%$ & $37.9 \%$ & NS \\
\hline $\mathrm{CABG}$ & $19.0 \%$ & $6.9 \%$ & NS \\
\hline Smoking & $71.4 \%$ & $65.5 \%$ & NS \\
\hline Hypertension & $19.0 \%$ & $17.2 \%$ & NS \\
\hline Ventricular fibrillation & $9.5 \%$ & $6.9 \%$ & NS \\
\hline Previous MI & $4.8 \%$ & $10.3 \%$ & NS \\
\hline $\begin{array}{l}\text { Peripheral vascular } \\
\text { disease }\end{array}$ & $4.8 \%$ & $0 \%$ & NS \\
\hline \multirow[t]{3}{*}{ Vessel disease } & $41.2 \%$ & $48.0 \%$ & NS \\
\hline & $23.5 \%$ & $24.0 \%$ & NS \\
\hline & $35.3 \%$ & $28.0 \%$ & NS \\
\hline CADin.family & $-42,9 \%$ & $58.6 \%$ & $\mathrm{NS}$ \\
\hline $\begin{array}{l}\text { Psychiatric disease in } \\
\text { family }\end{array}$ & $9.5 \%$ & $10.3 \%$ & NS \\
\hline Previous depression & $0 \%$ & $44.8 \%$ & $<0.001$ \\
\hline \multicolumn{4}{|l|}{ At sampling } \\
\hline Months post-MI & $6.0(2.2)$ & $5.2(2.8)$ & NS \\
\hline BDI & $3.5(2.7)$ & $14.1(8.0)$ & $<0.00 \mathrm{i}$ \\
\hline $\begin{array}{l}\text { Stopped smoking after } \\
\text { MI }\end{array}$ & $52.4 \%$ & $34.5 \%$ & NS \\
\hline Aspirin & $95.2 \%$ & $93.1 \%$ & NS \\
\hline Beta-blocker & $81.0 \%$ & $93.1 \%$ & NS \\
\hline Statin & $95.2 \%$ & $93.1 \%$ & NS \\
\hline ACE-inhibitor & $38.1 \%$ & $20.7 \%$ & NS \\
\hline
\end{tabular}

p-value = 2-tailed level of significance; Values are means (s.d.); NS : not statistically significant; BMI: body mass index: LVEF: left ventricular ejection fraction; MI: myocardial infarction: $\mathrm{CK}_{\max }$. maximum levels of creatinine kinase during hospitalisation for MI, ASAT max maximum levels of aspartate aminotransferase during hospitalisation for MI; PTCA: pereutaneous transluminal coronary angioplasty; CABG; coronary artery bypass grafting: $\mathrm{CAD}$ : coronary artery disease; BDI: Beck Depression Inventory; CCB: calcium channel blocker. 


\section{Results}

PUFA ratio's in serum phospholipids

Depressed post-MI patients had significantly higher AA/EPA ratios as compared to the nondepressed group (15.09 and 11.19 respectively, $\mathrm{p}=0.04$ ). Bivariate regression analyses showed that cessation of smoking since MI, continuing smoking, ACE-I and CCB were significant predictors of AA/EPA ratio (all p's $<0.05$ ). The multivariate regression model was highly significant ( $F=3.1$, df $\left.=5.44, \mathrm{p}=0.017, \mathrm{R}^{2}=0.26\right)$ and was as follows:

$\mathrm{AA} / \mathrm{EPA}=\alpha+4.1 \mathrm{x}$ depression $-4.4 \times \mathrm{ACE}-3.6 \mathrm{x}$ cessation of smoking $+1.6 \mathrm{x}$ continuing smoking $+2.7 \times$ CCB. Depression predicted AA/EPA ratio with $p=0.03$ and ACE-I predicted AA/EPA ratio with $\mathrm{p}=0.04$.

Table 2 shows that the sum of PUFAs was equal in both groups. There was no significant difference between the groups regarding $n-6 / n-3$ LCPUFA ratio $(p=0.62)$. Bivariate regression analyses showed that a positive history of CAD in the family, ACE-I and CCB were significant predictors of $\mathrm{n}-6 / \mathrm{n}-3$ LCPUFA ratio $(\mathrm{p}<0.05$ ). In the multivariate regression model. $(\mathrm{F}=4.6, \mathrm{df}=4.45, \mathrm{p}=0.003$, $R^{2}=0.29$ ), a positive history of CAD in the family predicted $n-6 / n-3$ LCPUFA ratio with $p=0.05$ $(\beta=0.4)$ and ACE-I with $p=0.02(\beta=-0.5)$.

\section{Parameters of inflammation}

Regarding markers of inflammation, there was neither a significant difference in. Zn plasma levels between depressed and non-depressed post-MI patients ( 96.42 and 92.44 respectively, $\mathrm{p}=0.27$ ) nor a significant difference in high sensitive (hs) CRP serum levels (3.91 and 4.71 respectively, $\mathrm{P}=$ 0.62). The difference remained non-significant after controlling for potential confounding factors.

\section{Treatment effect of antidepressants on PUFAs}

Because of 3 dropouts in the eight-week acute treatment phase of the trial, 26 depressed patients had an additional blood collection after 8 weeks. Treatment with mirtazapine was associated with decreased AA/EPA ratio's, whereas in the placebo group, AA/EPA ratio increased $(-0.7$ and I respectively, $\mathrm{p}=0.5$ ) (see table 2). The regression model with $\mathrm{AA} / \mathrm{EPA}$ ratio at week 8 as dependent variable and baseline AA/EPA ratio and mirtazapine/placebo as predictors, was not significant $(\mathrm{p}=0.53)$. However, Cooks distances analyses showed that the model was very instable as indicated by four large Cook's measures. After excluding these four cases ( 1 in the mirtazapine group and 3 in the placebo group) a highly significant treatment effect emerged ( $p=0.008, \beta=7.1)$. 
Table 2. Fatty acid composition and immune parameters in non-depressed and depressed post-MI patients, and after treatment.

\begin{tabular}{|c|c|c|c|c|}
\hline & $\begin{array}{l}\text { Non-depressed } \\
\text { post-MI } \\
\text { patients } \\
(\mathrm{n}=21)\end{array}$ & $\begin{array}{c}\text { Depressed } \\
\text { post-MI } \\
\text { patients } \\
(\mathrm{n}=29)\end{array}$ & $\begin{array}{l}\text { Depressed post-MI } \\
\text { patients after } \\
\text { treatment } \\
\text { with mirtazapine } \\
\quad(n=10)\end{array}$ & $\begin{array}{l}\text { Depressed post- } \\
\text { MI patients after } \\
\text { treatment } \\
\text { with placebo } \\
(\mathrm{n}=16)\end{array}$ \\
\hline 乏PUFA \% & $37.85(1.1)$ & $38.29(1.2)$ & $38.71(1.2)$ & $38.48(1.6)$ \\
\hline $18: 2 \mathrm{n} 6(\mathrm{LA}) \%$ & $18.07(3.3)$ & $18.93(3.0)$ & $18.91(2.2)$ & $19.19(2.7)$ \\
\hline $18: 3 \mathrm{n} 3(\mathrm{ALA}) \%$ & $0.16(0.0)$ & $0.18(0.0)$ & $0.16(0.0)$ & $0.17(0.0)$ \\
\hline En6 LCPUFA \% & $13.80(1.9)$ & $13.78(2.2)$ & $14.06(2.0)$ & $14.07(2.2)$ \\
\hline In 3 LCPUFA $\%$ & $5.58(1.7)$ & $5.17(1.3)$ & $5.56(1.0)$ & $5.03(1.2)$ \\
\hline $20: 4 \mathrm{n} 6(\mathrm{AA}) \%$ & $9.66(1.8)$ & $9.83(2.2)$ & $9.94(1.9)$ & $9.88(2.2)$ \\
\hline $20: 5 n 3$ (EPA) $\%$ & $1.03(0.4)$ & $0.80(0.4)$ & $0.86(0.4)$ & $0.81(0.5)$ \\
\hline $22: 6 \mathrm{n} 3$ (DHA) $\%$ & $3.67(1.3)$ & $3.46(0.9)$ & $3.67(0.8)$ & $3.20(0.9)$ \\
\hline $\begin{array}{l}\text { n6/n3 LCPUFA } \\
\text { ratio }\end{array}$ & $2.69(0.8)$ & $2.79(0.7)$ & $2.63(0.7)$ & $2.98(0.9)$ \\
\hline AA/EPA ratio & $11.19(5.1)$ & $15.09(7.3)^{*}$ & $13.54(6.9)$ & $16.09(9.2)$ \\
\hline $22: 5 n 6 / 20: 4 n 6$ & $1.75 \mathrm{E} 2$ & $1.66 \mathrm{E} 2$ & I.62E2 & $1.90 \mathrm{E} 2$ \\
\hline $22: 5 n 6 / 22: 6 n 3$ & $5.50 \mathrm{E} 2$ & 5.09E2 & $4.86 \mathrm{E} 2$ & $6.45 \mathrm{E} 2$ \\
\hline Zinc $\mu \mathrm{g} / \mathrm{dL}$ & $92.44(10.9)$ & $96.42(11.8)$ & $91.55(10.6)$ & $92.93(11.3)$ \\
\hline CRP mg/L & $4.71(3.5)$ & $3.91(6.3)$ & $6.35(3.7)$ & $2.39(1.7)$ \\
\hline
\end{tabular}

$* 0.042$

\section{Post-hoc correlations}

In post-hoc analyses, correlations between AA/EPA ratio and markers of inflammation were investigated. A negative correlation of $\mathrm{Zn}$ with $\mathrm{AA} / \mathrm{EPA}$ ratio (Pearson's $\mathrm{r}=-0.31, \mathrm{p}=0.051$ ) and n-3 LCPUFAs (Pearson's $\mathrm{r}=-0.39, \mathrm{p}=0.014$ ) was found. There was neither a significant correlation between hs CRP levels and AA/EPA ratio or n-6/n-3 LCPUFA ratio, nor a significant correlation between hs CRP and $\mathrm{Zn}$.

\section{Discussion}

Data from this study show that depression in post-Ml patients is significantly associated with higher AA/EPA ratios as compared to non-depressed post-MI patients. This significance remained after controlling for potential confounding factors. Depression after MI has been associated with increased cardiac mortality. The prognostic influence of depression seems to be mostly limited to fatal events due to increased risk of arrhythmia ?. LCPUFAs affect the excitability of cardiomyocytes and it can be postulated that if n-3 LCPUFAs favourably alter cardiac ion channel, function ${ }^{20,30}$, a relative n-3 LCPUFA deficiency may result in an increased vulnerability to 
ventricular fibrillation resulting in sudden cardiac death in the setting of MI. As evidence grows that depression is associated with higher AA/EPA levels and post-MI depression is associated with increased risk of arrhythmia, it may be hypothesized that a relative deficiency of n-3 LCPUFAs, may be an important pathophysiological link between depression and increased cardiac mortality post-MI.

Regarding the lipid hypothesis of major depression, it postulates that due to a n-3 LCPUFA depletion in the brain, most notably EPA and DHA (c22:6n3, docosahexanoic acid), membrane fluidity is decreased, which results in membrane dysfunction ${ }^{3 !}$. Changes in membrane fluidity, have been shown to alter the accessibility of the serotonin receptor to ligand binding due to vertical displacement of the receptor protein in the bilayer ${ }^{32}$ and to modulate the activity of tryptophan hydroxylase, the rate-limiting enzyme in serotonin synthesis ${ }^{14,33,34}$.

In addition to the essential contribution of PUFAs to the physical state of membranes, they also are involved in different regulatory processes. When cells are activated, their membrane lipids are rapidly remodelled to generate biologically active lipid mediators that can serve as intracellular or extracellular signals. AA is the most prominent precursor of n-6-derived eicosanoids (i.e. prostaglandines, thromboxanes, prostacyclines, leukotrines), and EPA of n-3-derived eicosanoids. AA-derived eicosanoids are often more proinflammatory and proaggregatory, and replacement of AA by n-3 LCPUFAs often results in a less active eicosanoid profile ${ }^{35-37}$. N-3 LCPUFA depletion in depressed post-MI patients can be postulated to increase thrombo-embolic events through a shift towards production of more prothrombotic eicosanoids.

The data from this study revealed an absence of increased inflammation in depressed post-MI patients as compared to non-depressed MI-patients. Beta-blockers, aspirin, statins, ace-inhibitors and calcium channel blockers have all been reported to influence inflammatory parameters ${ }^{38-41}$ ). It cannot be excluded that depression-related increased inflammation was present in an earlier phase and that increases of inflammation have been attenuated during a period of at least 3 months of treatment with at least three prescriptions of cardiac medications that influence inflammatory status. Taking into account that diet influences PUFA status, concentrations of linoleic acid (LA, CI8:2n6) and $\alpha$-linoleic acid (ALA, C18:3n3) were computed in both groups (table 2). Dietary n-3 and n-6 PUFA intake, as reflected by LA and ALA concentrations, were not statistically different between the depressed and non-depressed MI-patients. Ratio's of osbonic acid/AA $(22: 5 n 6 / 20: 4 n 6)$ and osbonic acid/DHA (22:5n6/22:6n3) were also computed, because dietary induced n-3 PUFA deficiency would result in increased ratios, due to replacement of DHA by osbonic acid ${ }^{42}$. There 
was no significant difference in osbonic acid/AA and osbonic acid/DHA ( $\mathrm{p}=0.63$ and $\mathrm{p}=0.64$, respectively) between the two groups (table 2 ).

\section{Effect of medication on PUFA status}

The results of bivariate and multivariate analyses were highly suggestive of an effect of cardiac medication on PUFA status. ACE-I and CCB predicted AA/EPA ratio in bivariate analyses and ACE-I remained a significant predictor in the multivariate regression model. Regarding statins, a specific effect on polyunsaturate composition has been reported ${ }^{43}$. A confounding effect of statins in the present study is improbable, as in both groups more than $93 \%$ of patients were prescribed statins. Few data are available on effects of CCB and ACE-I. Lipophilic calcium antagonists have been shown to inhibit lipid peroxidation in cellular membranes ${ }^{44,45}$ and captopril has also been shown to have antioxidant properties ${ }^{46}$. Lipids, by virtue of their location in cell membranes, are particularly vulnerable to peroxidation. DHA, with its high degree of unsaturation, is prone to lipid peroxidation, resulting in an unstable membrane structure, altered membrane fluidity and permeability, and impaired signal transduction. Through these mechanisms, a potential effect of ACE-I and CCB, such as found in the data of this study, might be explained.

Regarding AA/EPA levels after 8 weeks treatment with mirtazapine or placebo, mirtazapine was associated with a non-significant decrease in AA/EPA levels (table 2). After excluding four outlying cases based on Cook's distance, a highly significant treatment effect emerged ( $p=0.008, \beta=$ -7.1). Two previous studies have failed to show an effect of antidepressants fluoxetine, amisulpuride and lofepramine on PUFA status ${ }^{14,15}$. Mechanisms by which mirtazapine may lower AA/EPA ratio are not known.

PUFA intervention studies have shown to reduce sudden cardiac death and primary cardiac arrest in MI patients ${ }^{4,5,47}$. And in patients with bipolar disorder, double blind placebo-controlied adjunctive therapy with n-3 PUFAs (combination of EPA and DHA), resulted in significant symptom reduction and a significantly longer period of remission ${ }^{48}$. While addition of EPA alone resulted in a significant symptom reduction compared to placebo in patients with depression in two studies ${ }^{49,50}$. DHA monotherapy failed to show a significant effect ${ }^{51}$. It is unclear at this time whether one particular n-3 fatty acid is potentially more effective than others or whether the combination of EPA and DHA is potentially more effective than either DHA or EPA alone.

In conclusion, the data of the present study give support to the hypothesis that an unfavourable PUFA profile, consisting of lower EPA levels and higher AA levels, is associated with depression post-MI. Low AA/EPA ratios may be the pathophysiological link between depression and increased 
cardiac mortality in the post-MI period, by modulating neurotransmitter pathways in the brain on the one hand and through acting on ion channels in the cardiomyocyte on the other hand. Preventive supplementation with n-3 PUFAs might be considered in patients with a positive history for depression. Omega 3 supplementation studies in the early phase of depression after MI are needed to assess a positive effect of n-3 PUFAs on the risk of developing depression and/or arrhythmia in: the post-MI period.

\section{Acknowledgment}

This study was supported by grant no. 2002B207 of "The Netherlands Heart Foundation".

\section{References}

1. Frasure-Smith N, Lesperance F, Talajic M. Depression following myocardial infarction: impact on 6months survival. JAMA. 1993;270:1819-1825.

2. Bush DE, Ziegelstein RC, Tayback M, Richter D, Stevens S, Zahalsky H, Fauerbach JA. Even minimal symptoms of depression increase mortality risk after acute myocardial infarction. $\mathrm{Am} \mathrm{J}$ Cardiol. 2001:88:337-41.

3. Kromhout D, Bosschieter EB, de Lezenne Coulander C. The inverse relation between fish consumption and 20-year mortality from coronary heart disease. $N$ Engl J Med. 1985;312:1205-9.

4. Albert CM, Hennekens CH, O'Donnel CJ, Ajani UA, Carey VJ, Willet WC, Ruskin JN. Fish consumption and risk of cardiac death. JAMA. 1998;279:23-28.

5. Burr ML, Fehily AM, Gilbert JF, Rofers S, Holliday RM, Sweetnam PM, Elwood PC, Deadman NM. Effects of changes in fat, fish and fibre intakes on death in myocardial reinfarction: diet and reinfarction trial. Lancet. 1989;2:757-761.

6. de Lorgeril M, Renaud S, Mamelle N, Salen P, Martin J, Monjaud I, Guidollet J, Touboul P, Delaye J. Mediterranean alpha-linolenic acid-rich diet in secondary prevention of coronary heart disease. Lancet. 1994;343:1454-9.

7. Investigators G-P. Dietary supplementation with n-3 polyunsaturated fatty acids and vitamin $\mathrm{E}$ after myocardial infarction: results of the GISSI-Prevenzione trial. Lancet. 1999;354:447-55.

8. Marchioli R, Barzi F, Bomba E, Chieffo C, Di Gregorio D, Di Mascio R, Franzosi MG, Geraci E, Levantesi G, Maggioni AP, Mantini L, Marfisi RM, Mastrogiuseppe G, Mininni N, Nicolosi GL. Santini M, Schweiger C, Tavazzi L, Tognoni G, Tucci C, Valagussa F. Early protection against sudden death by n-3 polyunsaturated fatty acids after myocardial infarction: time-course analysis of the results of the Gruppo Italiano per lo Studio della Sopravvivenza nell'Infarto Miocardico (GISSI)Prevenzione. Circulation. 2002;105;1897-903.

9. Leaf A, Kang JX, Xiao YF, Billman GE. Clinical prevention of sudden cardiac death by n-3 polyunsaturated fatty acids and mechanism of prevention of arrhythmias by n-3 fish oils. Circulation. 2003;107:2646-52.

10. Weissman MM, Bland RC, Canino GJ, Faravelli C, Greenwald S, Hwu HG, Joyce PR, Karam EG, Lee CK, Lellouch J, Lepine JP, Newman SC, Rubio-Stipec M, Wells JE, Wickramaratne PJ, Wittchen H, Yeh EK. Cross-national epidemiology of major depression and bipolar disorder. Jama. 1996:276:293-9.

11. Hibbeln JR. Fish consumption and major depression [letter] [see comments]. Lancet. 1998;351:1213. 
12. Tanskanen A, Hibbeln JR, Tuomilehto J, Uutela A, Haukkala A, Viinamaki H, Lehtonen J, Vartiainen E. Fish consumption and depressive symptoms in the general population in Finland. Psychiatr Serv. 2001;52:529-31.

13. Maes M, Smith R, Christophe A, Cosyns P, Desnyder R, Meltzer H. Fatty acid composition in major depression: decreased $n 3$ fractions in cholesteryl esters and increased $C 20: 4 n 6 / C 20: 5 n 3$ ratio in cholesteryl esters and phospholipids. J Affect Dis. 1996;38:35-46.

14. Maes M, Christophe' A, Delanghe J, Altamura C, Neels H, Meltzer H. Lowered $\mathrm{n} 3$ polyunsaturated fatty acids in serum phospholipids and cholesteryl esters of depressed patients. Psychiatry Res. 1999;85:275-291.

15. Peet M, Murphy B, Shay J, Horrobin D. Depletion of omega-3 fatty acid levels in red blood cell membranes of depressive patients. Biol Psychiatry. 1998;43:315-9.

16. Adams PB, Lawson S, Sanigorski A, Sinclair AJ. Arachidonic acid to eicosapentaenoic acid ratio in blood correlates positively with clinical symptoms of depression. Lipids. 1996;31 (Suppl):S157-61.

17. Edwards R, Peet M, Shay J, Horrobin D. Omega-3 polyunsaturated fatty acid levels in the diet and in red blood cell membranes of depressed patients. Journal of Affective Disorders. 1998;48:149-155.

18. Hibbeln J. Long-chain Polyunsaturated fatty Acids in Depression and related Conditions. In: Phospholipid Spectrum Disorder in Psychiatry. Lancashire: Marius Press; 1999:195-209.

19. Ridker PM, Rifai N, Stampfer MJ, Hennekens CH. Plasma concentration of interleukin-6 and the risk of future myocardial infarction among apparently healthy men. Circulation. 2000;101:1767-72.

20. Anzai T, Yoshikawa T, Shiraki H. Asakura Y, Akaishi M, Mitamura H, Ogawa S. C-reactive protein as a predictor of infarct expansion and cardiac rupture after a first Q-wave acute myocardial infarction. Circulation. 1997:96:778-84.

21. Danner M, Kasl SV, Abramson. JL, Vaccarino V. Association between depression and elevated Creactive protein. Psychosom Med. 2003;65:347-56.

22. Suarez EC. Joint effect of hostility and severity of depressive symptoms on plasma interleukin-6 concentration. Psychosom Med. 2003;65:523-7.

23. Suarez EC, Krishnan RR, Lewis JG. The relation of severity of depressive symptoms to monocyteassociated proinflammatory cytokines and chemokines in apparently healthy men. Psychosom Med. 2003;65:362-8.

24. Maes M, Vandoolaeghe E, Neels H, Demedts P, Wauters A, Meltzer HY, Altamura C, Desnyder R. Lower serum zine in major depression is a sensitive marker of treatment resistance and of the immune/inflammatory response in that illness. Biol Psychiatry. 1997:42:349-58.

25. McLoughlin IJ, Hodge JS. Zinc in depressive disorder. Acta Psychiatr Scand. 1990;82:45 I-3.

26. van den Brink RHS, van Melie J, Honig A, Schene AH, Crijns HJGM, Lambert FPG, Ormel J. Treatment of depression after myocardial infarction and the effects on cardiac prognosis and quality of life: Rationale and outline of the Myocardial INfarction and Depression - Intervention Trial (MIND-IT). Am Heart J. 2002;144:219-225.

27. Anttila SA, Leinonen EV. A review of the pharmacological and clinical profile of mirtazapine. CNS Drug Rev. 2001:7:249-64.

28. Hair JF, ed. Multivariate data analysis. 5th ed. Upper Saddle River, New Yersey: Prentice-Hall, Inc. A Simon\&Schuster Company; 1998.

29. Lemaitre RN, King IB, Mozaffarian D, Kuller LH, Tracy RP, Siscovick DS. n-3 Polyunsaturated fatty acids, fatal ischemic heart disease, and nonfatal myocardial infarction in older adults: the Cardiovascular Health Study. Am J Clin. Nutr. 2003;77:319-25.

30. Siscovick DS, Lemaitre RN, Mozaffarian D. The fish story: a diet-heart hypothesis with clinical implications: n-3 polyunsaturated fatty acids, myocardial vulnerability, and sudden death. Circulation. 2003:107:2632-4.

31. Hibbeln IR, Salem N, Jr. Dietary polyunsaturated fatty acids and depression: when cholesterol does not satisfy. Am J Clin Nutr. 1995;62:1-9.

32. Heron DS, Shinitzky M, Hershkowitz M, Samuel D. Lipid fluidity markedly modulates the binding of serotonin to mouse brain membranes. Proceedings of the National Academy of Sciences of the United States of America. 1980:77:7463-7467. 
33. Yehuda S, Rabinovitz S, Mostofsky DI. Essential fatty acids are mediators of brain biochemistry and cognitive functions. $J$ Neurosci Res. 1999;56:565-70.

84. Block. ER, Edwards D. Effect of plasma membrane fluidity on serotonin transport by endothelial cells. Am J Physiol. 1987;253:C672-8.

35. Calder PC. Immunoregulatory and anti-inflammatory effects of n-3 polyunsaturated fatty acids. Braz J Med Biol Res. 1998;31:467-90.

36. Vericel E, Calzada C, Chapuy P, Lagarde M. The influence of low intake of n-3 fatty acids on platelets in elderly people. Atherosclerosis. 1999;147:187-92.

37. Malle E, Kostner GM. Effects of fish oils on lipid variables and platelet function indices. Prostaglandins Leukot Essent Fatty Acids. 1993;49:645-663.

38. Ohtsuka T, Hamada M, Hiasa G, Sasaki O, Suzuki M, Hara Y, Shigematsu Y, Hiwada K. Effect of beta-blockers on circulating levels of inflammatory and anti-inflammatory cytokines in patients with dilated cardiomyopathy. J Am Coll Cardiol. 2001;37:412-7.

39. Kennon S, Price CP, Mills PG, Ranjadayalan K, Cooper J, Clarke H, Timmis AD. The effect of aspirin on C-reactive protein as a marker of risk in unstable angina. $J \mathrm{Am}$ Coll Cardiol. 2001;37:1266-70.

40. Kent SM, Flaherty PJ, Coyle LC, Markwood TT, Taylor AJ. Effect of atorvastatin and pravastatin on serum C-reactive protein. Am Heart J. 2003;145:e8.

41. Wei GC, Sirois MG, Qu R, Liu P, Rouleau JL. Subacute and chronic effects of quinapril on cardiac cytokine expression, remodeling, and function after myocardial infarction in the rat. $J$ Cardiovase Pharmacol. 2002;39:842-50.

42. Bourre JM, Dumont O, Durand G. Brain phospholipids as dietary source of (n-3) polyunsaturated fatty acids for nervous tissue in the rat. $J$ Neurochem. 1993;60:2018-28.

43. Hibbeln JR, Salem N, Jr. Risks of cholesterol-lowering therapies. Biol Psychiatry. 1996;40:686-7.

44. Mason RP, Mak IT, Trumbore MW, Mason PE. Antioxidant properties of calcium antagonists related to membrane biophysical interactions. Am J Cardiol. 1999;84:16L -22 L.

45. Mason RP, Walter MF, Trumbore MW, Olmstead EG, Jr., Mason PE. Membrane antioxidant effects of the charged dihydropyridine calcium antagonist amlodipine. $J$ Mol Cell Cardiol. 1999:31:275-81.

46. Chopra M, Beswick H, Clapperton M, Dargie HJ, Smith WE, McMurray J. Antioxidant effects of angiotensin-converting enzyme (ACE) inhibitors: free radical and oxidant scavenging are sulfhydryl dependent, but lipid peroxidation is inhibited by both sulfhydryl-and nonsulfhydryl-containing ACE inhibitors. J Cardiovasc Pharmacol', 1992;19:330-40.

47. Siscovick DS, Raghunathan TE, King 1, Weinmann S, Wicklund KG, Albright J, Bovbjerg V, Arbogast P, Smith H, Kushi LH, Cobb LA, Copass MK, Psaty BM, Lemaitre R, Retzlaff B, Childs $M_{n}$ Knopp RH. Dietary intake and cell membrane levels of long chain n-3 polyunsaturated fatty acid and the risk of primary cardiac arrest. JAMA. 1995;274:1363-1367.

48. Stoll AL, Severus WE, Freeman MP, Rueter S, Zboyan HA, Diamond E, Cress KK, Marangell LB. Omega, 3 fatty acids in bipolar disorder: a preliminary double-blind, placebo-controlled trial [see comments]. Arch Gen Psychiatry. 1999;56:407-12.

49. Peet M, Horrobin DF. A dose-ranging study of the effects of ethyl-eicosapentaenoate in patients with ongoing depression despite apparently adequate treatment with standard drugs. Arch Gen Psychiatry. 2002:59:913-9.

50. Nemets B, Stahl Z, Belmaker RH. Addition of omega-3 fatty acid to maintenance medication treatment for recurrent unipolar depressive disorder. Am J Psychiatry. 2002;159:477-9.

51. Marangell LB, Martinez JM, Zboyan HA, Kertz B, Kim HF, Puryear LJ. A double-blind, placebocontrolled study of the omega-3 fatty acid docosahexaenoic acid in the treatment of major depression. Am J Psychiatry. 2003;160:996-8. 



\section{PART II}

Chapter 3

Increased coronary events in depressed cardiovascular patients: $5-\mathrm{HT}_{2 \mathrm{~A}}$ receptor as missing link?

Annique Schins, Adriaan Honig, Harry Crijns, Leo Baur, Karly Hamulyák Psychosomatic Medicine 2003.65: 729-737 


\section{Abstract}

Objective: Major depressive disorder and depressive symptoms have been identified as independent risk factors for cardiac morbidity and mortality in patients with ischaemic heart disease. Increased susceptibility to platelet activation has been proposed as one of the mechanisms by which depression acts as a significant risk factor for thrombotic events. In this review data on platelet activation and platelet aggregation measures in depressed patients with or without concomitant cardiovascular disease is given. Data on the influence of antidepressants on parameters of platelet activation are summarized.

Methods: A literature search was done by checking MEDLINE Advanced and Psyclnfo from 1990 to 2003 and through checking the bibliographies of these sources. The following key words were used for this search: platelet activation, platelet aggregation, depression, depressive disorder, ischaemic heart disease, calcium, serotonin.

Results: There is an indication of enhanced platelet activation and aggregation in depressed patients. Next, patients with a depressive disorder, show signs of a hyperactive platelet 5$\mathrm{HT}_{2 \mathrm{~A}}$ receptor signal transduction system. as measured by increased platelet calcium mobilization after stimulation of platelets with serotonin.

Concluslons: Depression appears to be associated with an increased susceptibility for serotoninmediated platelet activation. Upregulation and/or increased sensitivity of 5-HT $2 \mathrm{H}_{1 \mathrm{~B}}$ receptors and downregulated 5-HT transporter receptors in the periphery may contribute to increased risk of thrombo-embolic events in patients with depression and cardiovascular disease. Increased platelet reactivity based on a hyperreactive $5-\mathrm{HT}_{2 \mathrm{~A}}$ receptor signalling system, might be influenced by antidepressive medication. which antagonizes platelet $5-\mathrm{HT}_{2 \mathrm{~A}}$ receptors. 


\section{Introduction}

Major depressive disorder and symptoms of depression have been identified as independent risk factors for cardiac morbidity and mortality in patients with ischaemic heart disease. Most ${ }^{1-11}$ but not all ${ }^{12,13}$ studies found an increased mortality risk in patients with depressive disorder or patients with symptoms of depression. Odds ratio's for increased cardiac mortality of post-myocardial infarction (post-MI) depression range from 4.9 in older studies ${ }^{1,2}$ to $2.3-3.0^{3,10,11,14}$ in more recent ones. This increased risk is independent of other post-Ml risk factors such as left ventricular dysfunction, complex arrhythmias, and history of prior Mi. Major depression has been associated with serotonergic neurotransmission dysfunction ${ }^{15,16}$. Most post-mortem brain studies in suicide victims with a retrospective diagnosis of depression showed decreased hydroxytryptamine (5-HT) transporter binding sites ${ }^{16,17}$. Regarding $5-\mathrm{HT}_{2 \mathrm{~A}}$ receptors, post-mortem brain studies showed both an increase in 5- $\mathrm{HT}_{2 \mathrm{~A}}$ receptors in the brain of depressed suicide victims ${ }^{18-21}$ or no difference ${ }^{22-24}$. Recently, support for a decrease in brain 5-HT transporter receptors in depression was found in an in vivo study comparing 15 patients with unipolar depression and 15 controls using single-photon emission computed tomography (SPECT) ${ }^{25}$. In vivo imaging studies on $5-\mathrm{HT}_{2 \mathrm{~A}}$ receptors in the brain have shown no difference ${ }^{26-29}$, although some also found an increase ${ }^{30,3 !}$. Less is known about the status of the $5-\mathrm{HT}_{1}$ receptor in the brain because of paucity of highly selective radiotracers. There are at least five 5-HT, receptor subtypes, none of which are present on platelet membranes. 5-HT, receptors may however have a role in thrombotic processes because of their presence in the vascular system. There is evidence that $5-\mathrm{HT}_{1 \mathrm{~B}}$ and $5-\mathrm{HT}_{2} \mathrm{~A}$ receptors are present in smooth muscle cells of human coronary arteries ${ }^{32}$. Serotonin has been shown to promote proliferation of vascular endothelial cells, probably through the $5-\mathrm{HT}_{2 \mathrm{~A}}$ receptor ${ }^{33,34}$, and mediating vasoconstriction through $5-\mathrm{HT}_{2 \mathrm{~A}}{ }^{35,36}$ and $5-\mathrm{HT}_{1 \mathrm{~B}}$ receptors ${ }^{32}$. Because of similarity in the pharmacological and biochemical characteristics of platelet 5-HT transporter receptors and platelet $5-\mathrm{HT}_{2 \mathrm{~A}}$ receptors with those in the brain, it is hypothesized that the platelet receptor status may be analogue to the brain receptor status. Indeed there is considerable evidence of decreased platelet 5HT transporter binding sites, as measured by $[3 \mathrm{H}]$ imipramine binding ${ }^{37.38}{ }^{16}$, and increased platelet $5-\mathrm{HT}_{2 \mathrm{~A}}$ receptor binding in drug-free patients with major depression ${ }^{36-40}$. When binding was assessed with a more selective ligand $[3 \mathrm{H}]$ paroxetine, a decrease in platelet 5-HT transporter binding sites was however not found ${ }^{25}$. The reasons for this negative result are unclear. Thus, although the status of the $5-\mathrm{HT}$ transporter and the $5-\mathrm{HT}_{2 \mathrm{~A}}$ receptor have not been conclusively shown, and the correlation between the status of platelet and central serotonergic neurons needs 
further investigation, robust evidence for a serotonin dysregulation in mood disorders makes it plausible that $5-\mathrm{HT}_{2 \mathrm{~A}}$ receptors and 5-HT transporters may play a role in the aetiology of depression. In addition, changes in $5-\mathrm{HT}_{2 \mathrm{~A}}$ and $5-\mathrm{HT}_{1 \mathrm{~B}}$ receptor status may mediate atherogenic and pro-thrombotic mechanisms in the periphery ${ }^{41,42}{ }^{43}$. One mechanism accounting for increased serotonin mediated thrombosis could be up or down-regulation of peripheral 5-HT receptors. Another mechanism could be related to receptor sensitivity. Almost invariably researchers have reported enhanced platelet responsiveness of $5-\mathrm{HT}_{2 \mathrm{~A}}$ receptors in patients with depression ${ }^{44-47}$, suggesting an ethological role for the $5-\mathrm{HT}_{2 \mathrm{~A}}$ receptor in thrombotic complications in cardiovascular compromised depressed patients.

in a recent issue of this paper, von Kanel ${ }^{48}$ thoroughly reviewed literature on the effects of psychological factors on coagulation, anticoagulation and fibrinolysis measures and discussed the implications for cardiovascular disease. Research on state of activation of platelets in patients with depression has also been done by measuring (i) plasma levels of platelet-specific substances that are released from platelet granules (ii) plasma levels of molecules that are exposed on and shed from the platelet surface and (iii) agonist-induced platelet aggregation. None of the above mentioned markers is perfect but gives information about the state of platelet activation ${ }^{49}$. It has to be taken in account that markers may be sensitive to phlebotomy technique, diurnal variation and laboratory techniques. Moreover aspirin and other cardiovascular medication, such as statins, betablockers and nitrates have been shown to influence platelet function ${ }^{49}$.

This paper 1) reviews research regarding platelet activation and aggregation in depressed patients with or without cardiovascular disease 2) reviews data on platelet $5-\mathrm{HT}_{2 \mathrm{~A}}$ receptor signalling and 3) proposes a pathophysiologic mechanism regarding the platelet $5-\mathrm{HT}_{2 \mathrm{~A}}$ receptor which might contribute to explain the hypothesized relationship between increased cardiac morbidity and moriality and depressive disorder. Lastly suggestions for future research are given. The literature search was done by checking MEDLINE Advanced and Psyclnfo from 1990 to 2003 and through checking the bibliographies of these sources. The following key words were used for searching: platelei activation, platelet aggregation, depression, depressive disorder, ischaemic heart disease, calcium, serotonin. Before reviewing the literature on research about platelet activation in depressed patients with or without concomitant cardiovascular disease, the physiology of platelet activation will be summarized. 


\section{Physiology of platelet activation}

Exposure of platelets to damaged endothelium, shear stress, hypercholesterolemia and circulating substances, like serotonin, can all initiate platelet activation. Upon activation first a shape change of platelets is observed. This is followed by exposure of platelet membrane receptors and proteins and a release reaction consisting of extrusion of active substances from intraplatelet organelles by a mechanism of exocytose. Released substances from platelets induce local platelet adhesion, aggregation, vasoconstriction and clot formation, eventually leading to local vascular occiusion. The external plasma membrane and the open canalicular system are studded with glycoproteins that act as receptors for different ligands. Serotonin can bind platelet 5-HT transporters and 5- $\mathrm{HT}_{2 \mathrm{~A}}$ receptors. Stimulation of platelet $5-\mathrm{HT}_{2 \mathrm{~A}}$ receptors leads to a series of post receptor signals which ultimately induce calcium mobilization from internal storage sites ${ }^{50,51}$. Calcium mobilization is required for platelet activation in the approximate order of shape change, aggregation, dense granule secretion and $\alpha$-granule secretion. Calcium is also required for the hydrolysis of platelet membrane phosphatidylinositol and phosphatidylcholine, yielding arachidonic acid (AA) which is converted into thromboxanes, prostaglandines and prostacyclines. This conversion of AA is blocked by aspirin ${ }^{52}$. Thromboxane A2 is a potent vasoconstrictor and inducer of the release reaction. Other plasma proteins such as fibrinogen, collagen, fibronectin and laminin contribute to adhesion, aggregation and extrusion of mitogenic substances upon binding to their respective receptors (GP $\mathrm{IIb} / \mathrm{III}, \alpha_{2} \beta_{1}, \alpha_{5} \beta_{1}, \alpha_{6} \beta_{1}$ ). Two additional receptors are involved in platelet adhesion: GP Ib/IX/V, the receptor for von Willebrand factor, and GP IV as receptor for collagen and thrombospondin ${ }^{53}$. Recently CD40L has been identified as another important prothrombotic and pro-inflammatory receptor of the platelet ${ }^{54}$. It is well documented that serotonin potentiates platelet responses, to. agonists such as adenosine diphosphate (ADP), collagen or thrombin 55.56 . Also stimulated platelets use serotonin to enhance their retention of procoagulant proteins on the cell surface ${ }^{57}, \alpha$-granulae contain platelet factor 4 (PF4), $\beta$-thromboglobulin ( $\beta$ TG), platelet derived growth factor, factor $\mathrm{V}$ and von Willebrand factor. PF4 inactivates heparin and facilitates ADP-induced platelet aggregation. $\beta \mathrm{TG}$ is an antiheparin molecule inhibiting endothelial prostacyclin (vasodilator) secretion. Fusion of the $\alpha$-granule membrane with the platelet membrane leads to expression of P. selectin on the platelet surface, acting as receptor for neutrophils and monocytes on thrombinactivated platelets ${ }^{53}$. Another organel in the platelet is the dense body, which contains ATP (adenosine triphosphate), ADP, catecholamines, calcium ions and serotonin. Enzymatic degradation of serotonin occurs either by monoamine oxidase A in the liver or in pulmonary endothelium. 
Serotonin is taken up by platelets. As long as platelets do not aggregate, peripheral blood contains little or no free serotonin ${ }^{58}$.

As already mentioned, platelet function can be studied in several ways. Clinical studies on platelet activation in depressed patients with or without cardiovascular disease are reviewed which measured a) platelet specific release products, such as $\beta \mathrm{TG}$ and PF4 b) molecules that are expressed on and shed from the platelet surface, such as $\mathrm{P}$-selectin, glycoprotein $\mathrm{Ilb} / \mathrm{IIla}$, phophatidylserine and activated factor $\mathrm{V}$ and $\mathrm{c}$ ) agonist-induced platelet aggregation.

\section{Platelet activation in depression}

It has been suggested that psychological stress activates platelets ${ }^{59,60}$. A significant relationship was found between stress-induced platelet activation and hostility as measured by BTG levels in patients with CHD. Interestingly a positive relationship was also found between type A behavior and $\beta$ TG levels ${ }^{61}$. The same group replicated this finding with another marker of platelet activation, fibrinogen receptor activation and binding. In both studies no difference in platelet activation between CHD patients and controls could be found ${ }^{62}$. The study of Laghrissi-Thode ${ }^{63}$ was the first to report significantly elevated mean $\beta$ TG and PF4 plasma levels in 21 depressed patients suffering concurrently from ischaemic heart disease (IHD) as compared to patients with IHD alone $(\mathrm{n}=8)$ and controls $(n=17)$. The increased levels remained elevated despite use of aspirin in 18 of the 21 patients with depression and IHD. Also Pollock ${ }^{64}$ found significantly elevated mean $\beta$ TG and PF4 plasma levels in 17 depressed patients with IHD, but results have to be interpreted cautiously because the control group was not adequate to draw conclusions on the effect of depression alone (it consisted of 16 healthy controls). In order to investigate enhanced platelet reactivity in depressive post-MI patients, Kuijpers ${ }^{65}$ compared 12 post-MI patients with depression to 12 post-MI patients without depression. A significant increase of PF4 was detected in the depressed group and a trend toward significance for $\beta$ TG levels. Although sample size was small, baseline characteristics of both groups were homogeneous. Confounding factors such as aspirin use, use of other cardiovascular medication and smoking were evenly distributed. The first study to assess platelet activation in somaticaily healthy depressed patients was done by Musselman ${ }^{66}$. Annexine V, PACl, anti-LIBSS1, BTG and PF4 plasma levels were assessed in 12 medication-free patients with major depression and 8 normal controls at rest and following orthostatic challenge. Depressed patients exhibited significantly higher procoagulant activity at baseline as compared to controls as assessed by annexine $\mathrm{V}$ binding (detects phosphatidylserine) and following orthostatic challenge as assessed by $\mathrm{PACl}$ (detects fibrinogen binding site of activated GPIIb/IIla receptor) and anti-LIBSI 
(detects GP IIIa epitope). No significant increase was detected in other markers of platelet activation, possibly due to the small size of both groups. In a second study by the same group ${ }^{67}$ again significant increases in some but not all platelet activation markers were found in depressed patients versus normal controls. However, results are difficult to interpret because both the depressed and the control group were heterogeneous for risk factors for IHD (e.g. hypertension, smoking, elevated cholesterol) and family history for psychiatric disorders. Enhanced collageninduced platelet secretion but not anti-LIBS binding was reported in a study comparing 21 depressed patients with 21 non-depressed patients ${ }^{68}$. Baseline characteristics were not significantly different for confounding factors such as smoking or medication. In a group of elderly depressed subjects with low cardiovascular disease burden, increased levels of $\beta$ TG and PF4 were assessed as compared to elderly controls ${ }^{69}$. The first study assessing P-selectin expression by Western blotting technique, showed significant elevation of P-selectin on platelet membranes in a group of 19 depressed patients as compared to 17 controls ${ }^{70}$. The finding was replicated in a study comparing 15 depressed patients (13 unipolar, 2 bipolar) with 15 healthy controls. Other markers of platelet activation such as GPIb receptor expression and CD63 were also significantly increased, except from integrin receptor $\alpha_{4 b} \beta_{m a}{ }^{71}$. Finally, increased secretion of $\beta T G$ and PF4 and increased antiLIBS binding was assessed in a recent study of Musselman ${ }^{72}$. The study has however several limitations including relatively small sample sizes, diverse cohorts and differences in current medications.

Summarizing, although some studies had small groups and some had heterogeneous populations, making interpretation of the data more difficult, there is an indication of enhanced platelet activation in depressed patients as detected by plasma levels of platelet secretion products and procoagulant platelet protein expression.

Several studies addressed the effects of antidepressant medication on parameters of platelet activation. Platelet activation in the depressed group was significantly reduced after 6 weeks of open label treatment with paroxetine as demonstrated by diminished plasma levels of PF4 and diminished expression of activated factor $\mathrm{V}$ and $\mathrm{P}$-selectin ${ }^{67} .6$ weeks open label sertraline resulted in significant decrease of collagen-induced platelet secretion in 21 treated depressed patients ${ }^{68}$. This decrease was not correlated to changes in Beck Depression Inventory (BDI)-scores. In the previously mentioned study of Pollock ${ }^{64}$ after 6 weeks double blind treatment with either paroxetine or nortriptyline, mean PF4 and $\beta$ TG plasma levels decreased significantly in the patients treated with paroxetine but not with nortriptyline, while there was no difference in responder rate. No effect was found on P-selectin expression in depressed patients after 8 weeks open label 
treatment with bupropion ${ }^{70}$. In a large cohort, Serebruany et al. ${ }^{73}$ retrospectively compared differences in platelet activation in 126 patients with a selective serotonin reuptake inhibitor (SSRI) $(\mathrm{n}=34)$ or without a SSRI ( $\mathrm{n}=92$ ) before undergoing elective coronary artery stenting. Patients taking SSRI medication (fluoxetine, sertraline, paroxetine, fluvoxamine, citalopram) had significant lower expression of GPIIb/IIla receptor and P-selectin, however no significant difference could be found in other markers of platelet activation. The study has several limitations, more notably the absence of clinical diagnoses of depression, the heterogeneous population, the different cardiovascular medications and the different antidepressant medications.

In summary (see table 1), the limited number of studies relating on effect of medication, show that some antidepressants seem to have an effect on platelet activation in depressed patients with or without concomitant IHD by an as yet unknown mechanism. The effect does not seem to be related to the antidepressant effect per se as no relation of platelet activation to Hamilton Depression (HAMD) scores or recovery was found. Serotonin-selective uptake inhibitors all reduce platelet 5 . $\mathrm{HT}$ uptake but have varying effects on $5-\mathrm{HT}_{2 \mathrm{~A}}$ downregulation. Fluoxetine and paroxetine have been reported to have either no effect or increase $5-\mathrm{HT}_{2 \mathrm{~A}}$ receptor number, citalopram has been shown to down-regulate the $5-\mathrm{HT}_{2 \mathrm{~A}}$ receptor ${ }^{74}$. The $5-\mathrm{HT}_{2 \mathrm{~A}}$ receptor antagonist ketanserin has been shown to protect against platelet aggregation in animal models ${ }^{75}$. Data on platelet activation in patients on antidepressant medication with $5-\mathrm{HT}_{2 \mathrm{~A}}$ receptor antagonistic properties are as yet not available. Such studies are necessary to assess the possible role of $5-\mathrm{HT}_{2 \mathrm{~A}}$ receptors in enhanced platelet reactivity in depressed patients.

\section{Platelet aggregation in depression}

Another way to measure platelet activity is to measure spontaneous or agonist-induced aggregation. Nugent et al. ${ }^{76}$ preincubated plasma of a volunteer with plasma of either depressed patients or agematched controls. Platelet aggregation in plasma was measured after stimulation with among others serotonin, adenosine diphophate (ADP) and collagen. A significant reduction of platelet aggregatory response in plasma of depressed patients was detected as compared to controls. Serotonin-amplified platelet aggregation was assessed in a group of 76 depressed patients. No difference could be detected as compared to the normal controls, who were however significantly older ( 5 years) and had a significantly greater percentage of women ${ }^{77}$. There was no correlation between symptom severity or anxiety scores and platelet aggregation values. There was no difference between patients with and without a comorbid diagnosis of borderline personality disorder. Musselman ${ }^{66}$ assessed platelet aggregation in platelet rich plasma (PRP) after stimulation 
with collagen and ADP. An increased collagen induced platelet aggregation was detected in depressed patients following orthostatic challenge. The same group ${ }^{67}$ could not replicate this finding in a study where depressed patients and controls underwent a larger amount of excercise (60 sec. stepping on and off a platform) as compared to the mild orthostatic challenge in the previous study. As already mentioned, it must be noted that both the control group and the depressed group were heterogeneous for confounding factors such as ischaemic heart disease (IHD) risk factors and family history, which hampers interpretation of the data. In a study of Maes et al ${ }^{78}$, depressed patients did not exhibit increased platelet aggregation as measured in PRP after stimulation with ADP and collagen. Lederbogen ${ }^{79}$ studied platelet aggregability in 22 depressed patients both before and after 5 weeks of open label amitriptyline or paroxetine as well as in 24 healthy control subjects. The aim of the study was to evaluate whether remission of psychopathology, not which type of antidepressant, would influence platelet aggregability. Platelet aggregation was assessed in washed and rediluted platelets after stimulation with collagen and thrombin. Higher thrombin-induced platelet aggregability was found in the depressed group which persisted after improvement of depressive symptomatology after 5 weeks of treatment with amitriptyline or paroxetine. No data are available on any difference in amitriptyline versus the paroxetine group. In the aforementioned study of Serebruany ${ }^{73}$ decreased ADP and collagen induced platelet aggregation were reported in patients on selective serotonin re-uptake inhibitors (SSRIs). In a recent paper whole blood aggregation in response to stimulation with serotonin and ADP was assessed in 15 depressed patients versus 15 matched controls ${ }^{80652}$. A significant increased platelet aggregation to serotonin but not ADP was found in the depressed group as compared to controls. A non significant difference between depressed and control subjects in ADP-induced platelet aggregation was also reported measured by Walsh ${ }^{71}$.

In summary (see table 1), because of the great variability in procedures, it is not possible to pool results of platelet aggregation studies. In patients with a depressive disorder, measurement of increased platelet aggregation was detected after stimulation in vitro with serotonin and not ADP, a non 5-HT agonist, which suggests that in depressive subjects hypercoaguablity might in part be associated with 5-HT receptors. 
Table 1. Assessment of platelet activation in depressed patients with or without concomitant cardiovascular discase

\begin{tabular}{|c|c|c|c|c|}
\hline \multirow{2}{*}{ Source } & \multirow{2}{*}{ Population } & \multirow{2}{*}{ Treatment } & \multicolumn{2}{|c|}{ Platelet activation and aggregation } \\
\hline & & & Depressed vs. Non-depressed & Post-treatment vs pre-treatment \\
\hline $\begin{array}{l}\text { Laghrissi-Thode } \\
1997 \text { (63) }\end{array}$ & $\begin{array}{l}21 \mathrm{D}+1 \mathrm{HD} \\
8 \mathrm{IHD}, 17 \mathrm{C}\end{array}$ & & $\uparrow$ PTG, PF4 & \\
\hline Pollock, 2000 (64) & $\begin{array}{l}17 \mathrm{D}+1 \mathrm{HD} \\
16 \mathrm{C}\end{array}$ & 6 weeks double blind paroxetine or nortriptylline & T FTG, PF4 & $\begin{array}{l}\text { I BTG and PF4 in the paroxetine } \\
\text { but not in the nortriptylline group }\end{array}$ \\
\hline Kuypers, $2000(65)$ & $\begin{array}{l}12 \text { post }-\mathrm{MI}+\mathrm{D} \text {, } \\
12 \text { post-MI ND }\end{array}$ & & 1 PF4 & \\
\hline Mussclman, $1996(66)$ & $12 \mathrm{D} .8 \mathrm{C}$ & & $\begin{array}{l}\text { n.5. BTG, PF4 } \\
\text { t annexine V. PACl anti-LIBS }\end{array}$ & \\
\hline Musselman, $2000(67)$ & I5 D. $12 \mathrm{C}$ & 6 weeks open label paroxetine $20 \mathrm{mg} /$ day & † PF4, anti-LIBS, P-selectin & I PF4, anti-L.IBS, P-selectin \\
\hline Markovitz, $2000(68)$ & $21 \mathrm{D}, 21 \mathrm{C}$ & 6 weeks open label sertraline $50-100 \mathrm{mg} /$ day & $\begin{array}{l}\text { I platelet secretion } \\
\text { n.s. anti-LIBS }\end{array}$ & I platelet secretion \\
\hline Whyte, 2001 (69) & $\begin{array}{l}\text { 61. eiderly D } \\
12 \text { elderly C }\end{array}$ & & $\uparrow$ BTG, PF4 & \\
\hline Piletz, $2000(70)$ & $19 \mathrm{D} .17 \mathrm{C}$ & 8 weeks open label bupropion $75-450 \mathrm{mg}$ day & P-selectin & P-selectin remained elevated \\
\hline Walsh, 2002 (71) & $15 \mathrm{D}, 15 \mathrm{C}$ & & if P-selectin, GPlb, CD63 & \\
\hline Musselman, 2002 (72) & $15 \mathrm{D}, 12 \mathrm{C}$ & & $\uparrow$ anti-L.IBS, PF4 & \\
\hline Serebruany, 2001 (73) & $\begin{array}{l}\text { Retrospectively } 126 \\
\text { patients with CAD }\end{array}$ & 34 with SSRI. 92 without SSRI medication & & $\begin{array}{l}\text { ¿GPIIb/IIIa receptor expression, } \\
\text { P-selectin }\end{array}$ \\
\hline Nugent $1995(76)$ & 32 D. 40 & & I PA (serotonin, ADP, a.o.) & \\
\hline McBride 1994 (77) & $76 \mathrm{D}, 62 \mathrm{C}$ & & n.s. PA (ADP + serotonin) & \\
\hline Musselman, 1996 (66) & 12. D. $8 \mathrm{C}$ & & † PA (ADP, collagen) & \\
\hline Maes, $1996(78)$ & $79 \mathrm{D}, 16 \mathrm{C}$ & & n.s.PA (ADP, collagen) & \\
\hline Musseiman, $2000(67)$ & $15 \mathrm{D}, 12 \mathrm{C}$ & & n.s.PA (ADP, collagen) & \\
\hline Lederbogen, 2001 (79) & $22 \mathrm{D}, 24 \mathrm{C}$ & 5 weeks paroxetine or amitriptylline & i PA (collagen, thrombin) & n.s. PA \\
\hline Serebruany, 2001 (73) & $\begin{array}{l}\text { Retrospectively } 126 \\
\text { patients with CAD }\end{array}$ & 34 with SSRI, 92 without SSRI & & I PA (ADP; collagen+AA) \\
\hline Shimbo 2002 (80) & $15 \mathrm{D}, 15 \mathrm{C}$ & & i PA (with serotonin but not ADP) & \\
\hline Walsh 2002 (71) & $15 \mathrm{D}, 15 \mathrm{C}$ & & n.s.PA (ADP) & \\
\hline
\end{tabular}

$\mathrm{C}$-controls, $\mathrm{CAD}$ - coronary artery disease, $\mathrm{D}=$ depressed patients, $\mathrm{SSRI}=$ selective serotonin reuptake inhibitor, $\mathrm{n} . \mathrm{s}$. $=$ non-significant difference, $\beta \mathrm{TG}=\mathrm{beta-}$ thromboglobulin, IHD=-ischaemic heart disease, $\mathrm{ND}=$ non-depressed patients, $\mathrm{PF} 4=$ platelet factor 4 , post-MI= post-myocardial infaretion, $\mathrm{PA}=$ platelet aggregation, $\mathrm{AA}=$ arachidonic acid. 


\section{Platelet signal transduction and responsivity to receptor stimulation}

The aforementioned investigations evaluated aspects of platelet procoagulant status by measuring plasma levels of platelet release reaction products, by quantifying platelet surface protein expression and by assessing platelet aggregatory response to stimulation with agonists (see above). The mechanism behind the increased platelet procoagulant status has been investigated but not yet resolved. Platelet response to serotonin is mediated by the $5-\mathrm{HT}_{2 \mathrm{~A}}$ receptor. Increase in the effectiveness of serotonin to activate $5-\mathrm{HT}_{2 \mathrm{~A}}$ receptors could be explained by increased number of receptors on the platelet membrane, increased affinity of the receptor or by an increase of signal transduction somewhere beyond receptor stimulation. Serotonin operates by binding to the serotonin receptor, which belongs to the G-protein-coupled receptors (GPCRs). When the 5-HT receptor is activated, the coupled G protein is subsequently activated, which in turn stimulates the membrane effector protein phospholipase C (PLC). Phosphorylation (by PLC) of phosphatidylinositol 4,5-biphosphate $\left(\mathrm{PIP}_{2}\right)$ results in formation of the second messengers diacylglycerol (DG) and inositol 1,4,5-triphosphate $\left(\mathrm{IP}_{3}\right)$. IP, directly induces calcium release and DG indirectly by stimulation of protein kinase C (PKC) (Figure 1). Calcium mobilization is the common final pathway leading to platelet activation. Recent research suggests that depression is associated with dysregulation of the 5HT-receptor signal-transduction mechanism ${ }^{81,82}$. Moreover, mood-stabilizing drugs appear to interact with neural signal transduction systems ${ }^{82,83}$. Post $5-\mathrm{HT}_{2 \mathrm{~A}}$ receptor response can be studied by quantification of serotonin induced calcium mobilization. Although some studies found no significant difference ${ }^{50,84}$, evidence for significantly augmented platelet calcium mobilization in response to serotonin in patients with major depression as compared to controls is abundant ${ }^{51,85} 44-46,86-90$. Increased platelet $5-\mathrm{HT}_{2 \mathrm{~A}}$ receptor sensitivity was found in depressed patients without antidepressant medication $51,85-88.89,90$ as assessed by calcium response to serotonin stimulation. This increase as compared to healthy controls was also detected in some studies on depressive patients receiving antidepressant medication, mostly tricyclics ${ }^{44,45,89}$. Only one study reported a significantly lower response to serotonin stimulation in the group of depressive patients on SSRIs as compared to patients not taking SSRIs medication ${ }^{46}$. The medication and dosages were however not specified. In only one study ${ }^{46}$, a positive correlation was found between calcium response and symptom level.

Summarizing, patients with a depressive disorder, show signs of a hyperactive platelet 5- $\mathrm{HT}_{2 \mathrm{~A}}$ receptor signal transduction system as measured by increased platelet calcium mobilization after stimulation of the platelet with serotonin. In the abovementioned studies, patients treated with an 
antidepressant still appeared to have an increased 5- $\mathrm{HT}_{2 \mathrm{~A}}$ receptor response to stimulation with serotonin, although attenuated ${ }^{46,82,84}$.

Figure 1: Signal transduction of the 5- $\mathrm{HT}_{2 \mathrm{~A}}$ receptor

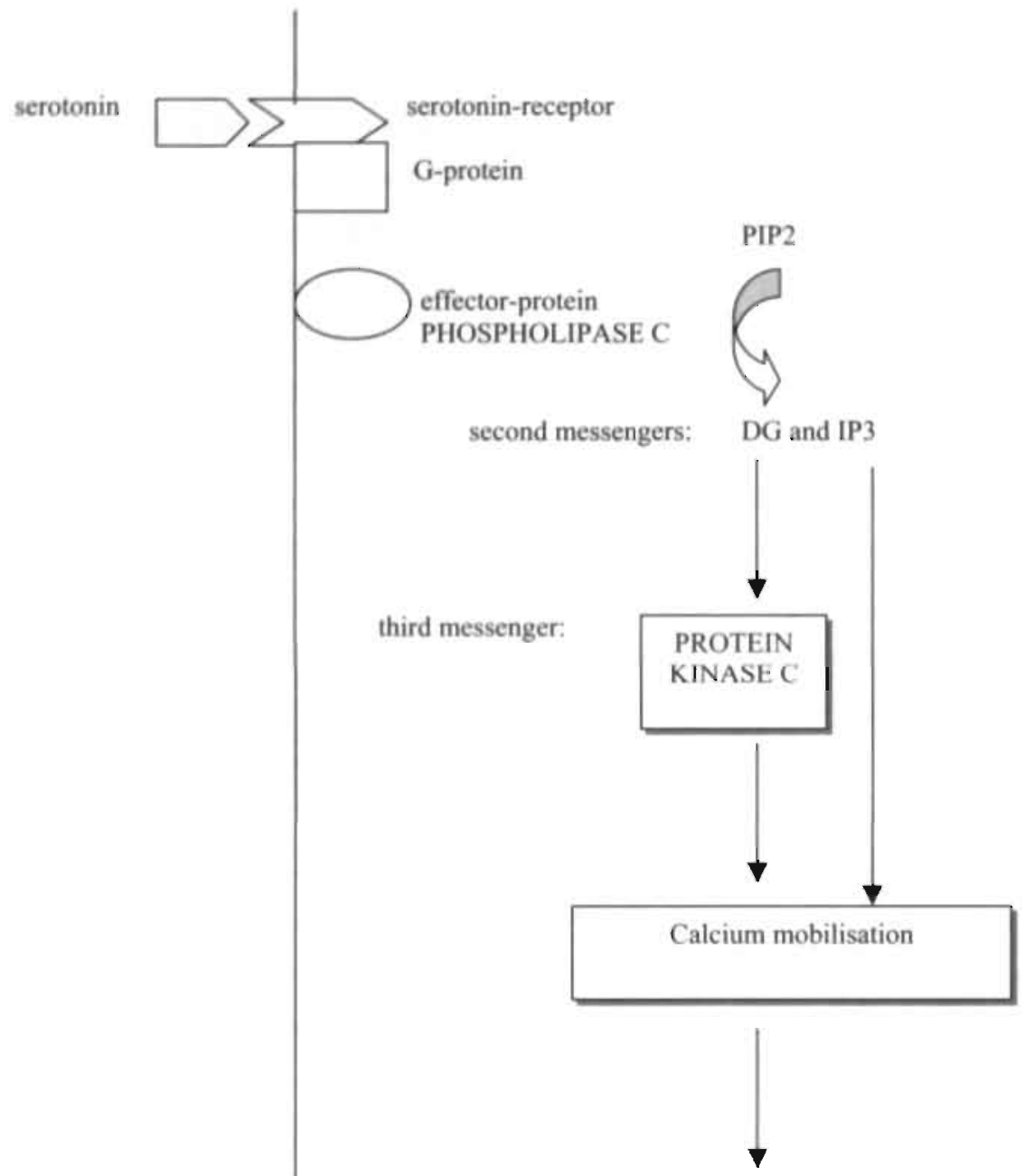

1. shape change

2. release reaction:

3. aggregation

PIP2 = phosphatidylinositol 4,5-biphosphate

IP3 = inositol 1,4,5-triphosphate

$\mathrm{DG}=$ diacylglycerol 


\section{Discussion}

Several studies have been done assessing state of platelet activation in depressed patients with or without concomitant cardiovascular disease. Depression was associated with increased platelet reactivity as assessed by increased plasma levels of PF4 and BTG, and increased expression of procoagulant platelet surface receptors. Enhanced platelet activation was also found in patients with depression and IHD as compared to non-depressed patients with IHD. Preliminary data showed that sertraline and paroxetine influenced platelet activation by lowering PF4 and BTG plasma levels and by decreasing pro-coagulant receptor expression on the platelet membrane surface. Mechanisms by which these SSRIs lower platelet hyperactivity are not clear.

Regarding platelet aggregation, studies are inconclusive. Methodological differences in measuring and inducing platelet aggregation may be at the basis of the described varying results. Studies, which did use collagen or adenosine diphosphate (ADP) as agonists, found no difference in platelet aggregation between depressed patients and controls. One study assessed the aggregatory response of platelets to stimulation with serotonin in whole blood. In this study a significant increase of platelet aggregation in depressed patients as compared to controls was found.

Up to now, evidence for the hypothesis that depression is associated with changes in central serotonergic function, is still growing. A limited number of in vivo studies and several post-mortem findings, point towards central upregulation of the $5-\mathrm{HT}_{2 \mathrm{~A}}$ receptor, decrease of the $5 \mathrm{HT}$ transporter receptor (5-HTT) and decreased rate of 5-HT uptake in patients with depressive disorder ${ }^{25}{ }^{18,19}$. The data are conflicting as to whether the same changes are present in serotonin receptors in the periphery. There is considerable evidence that in depression, platelet 5-HT transporter binding sites are decreased ${ }^{16,37,38}$ and some studies reported increased platelet $5-\mathrm{HT}_{2 \mathrm{~A}}$ receptor binding $36-40$, although studies using other ligands yielded different results ${ }^{25}$.

Enhanced platelet activation at the site of coronary artery stenosis is a risk factor for an acute thromboembolic event such as a recurrent infarction ${ }^{75}$ and on the long term elevated platelet reactivity has been associated with a higher rate of cardiovascular events in a follow-up period of five years ${ }^{91}$. At the site of vascular injury one can postulate that upregulation or increased sensitivity of 5-HT 2 N/B receptors and downregulated 5-HT transporter receptors, could result in more serotonin reaching $5-\mathrm{HT}_{2 \mathrm{~N} / \mathrm{B}}$ receptors on platelets and vascular endothelium and smooth muscle cells. Thus, increased platelet reactivity, together with the local effects of accumulation of serotonin at the atherosclerotic site - which results in decreased anti-thrombotic and anti-adhesive endothelial function - may lead to increased thrombo-embolic events. Indeed, serotonin not only causes vasoconstriction and aggregation of platelets, but also acts as a growth factor for smooth 
muscle cells and proliferation of endothelial cells and seems to induce endothelial injury itself $33,34,4232,35,36$

In the last decade aspirin has proven to reduce thrombotic complications, but aspirin alone is not sufficient to inhibit platelet-induced thrombosis in the case of artery stenting ${ }^{92}$. Indeed, in the abovementioned studies enhanced platelet reactivity remained in depressed patients with IHD as compared to non-depressed patients with IHD, despite the use of aspirin. This may imply that other mechanism behind increased platelet reactivity in depressed MI patients are involved other than the pathway blocked by aspirin. $5-\mathrm{HT}_{2 \mathrm{~A}}$ receptors are not influenced by routine antithrombotic medication. Based on the finding that in several studies a hyperactive platelet $5-\mathrm{HT}_{2 \mathrm{~A}}$ receptor signal transduction was detected in depressed patients, a possible mechanism contributing to increased cardiac morbidity and mortality in depression may be increased platelet reactivity based on increased responsiveness of the platelet 5- $\mathrm{HT}_{2 \mathrm{~A}}$ receptor to serotonin in depressed patients. Next, a genetic factor cannot be excluded regarding upregulation or supersensitivity of platelet transporter receptors and platelet $5-\mathrm{HT}_{2 \mathrm{~A}}$ receptors. This factor could act at the level of the megakaryocyte (in man 35,000 platelets $\mu \mathrm{l} /$ day are produced), as platelets are anuclear themselves. A recent study found an association between the genotype of the 5-HT tranporter-linked promoter region (the recessive I allele is associated with the production of a greater number of serotonin transporters) and increased BTG and PF4 levels of depressed elderly subjects ${ }^{69}$, suggesting a genetic factor that may influence cardiovascular mortality in depressed patients. Regarding the 5-HT $2 \mathrm{~A}$ receptor, an association has been found between allele $\mathrm{C}$ of the $102 \mathrm{~T} / \mathrm{C}$ polymorphism in $5-\mathrm{HT}_{2 \mathrm{~A}}$ receptor gene and major depressive disorder, but the significance is as yet unknown ${ }^{93}$. More studies are needed to confirm changes in platelet activation and changes in the coagulation and fibrinolytic systems in depressed patients. Regarding data on platelet activation, studies have either small sample sizes or miss an adequate control group to draw conclusions. Assessment of platelet activation in a homogeneous group of depressed patients with CAD, both before and after treatment in a double blind, placebo-controlled design with an antidepressant with $5-\mathrm{HT}_{2 \mathrm{~A}}$ receptor antagonistic properties, might shed more light on the abovementioned hypothesis ${ }^{94}$. 


\section{References}

1. Frasure-Smith N, Lesperance F, Talajic M. Depression following myocardial infarction: impact on 6months survival. JAMA. 1993;270:1819-1825.

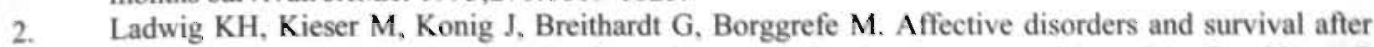
acute myocardial infarction (results from the post-infarction late potential study). Eur Heart J. 1991:12:959-964.

3. Penninx BW, Beekman AT, Honig A, Deeg DJ, Schoevers RA, van Eijk JT, van Tilburg W. Depression and cardiac mortality: results from a community-based longitudinal study. Arch Gen Psychiatry. 2001:58:221-7.

4. Jiang W, Alexander J, Christopher E, Kuchibhatla M, Gaulden L, Cuffe M, Blazing M, Davenport C, Califf R, Krishnan R, O'Connor CM. Relationship of Depression to Increased Risk of Mortality and Rehospitalization in Patients With Congestive Heart Failure. Arch Intern Med. 2001;161:1849-1856.

5. Abramson J, Berger A, Krumhoiz. HM, Vaccarino V. Depression and risk of heart failure among older persons with isolated systolic hypertension. Arch Intern Med. 2001:161:1725-30.

6. Denollet J. Personality and mortality after myocardial infarction. Psychosom Med. 1995;57:582-591.

7. Barefoot JC, Schroll M. Symtomps of depression, acute myocardial infarction, and total mortality in a community sample. Circulation. 1996;93:1976-1980.

8. Bush DE, Ziegelstein RC, Tayback M, Richter D, Stevens S, Zahalsky H, Fauerbach JA. Even minimal symptoms of depression increase mortality risk. after acute myocardial infarction. $\mathrm{Am}$. Cardiol. 2001;88:337-41.

9. Ariyo AA, Haan M. Tangen CM, Rutledge IC, Cushman M, Dobs A, Furberg CD. Depressive symptoms and risks of coronary heart disease and mortality in elderly Americans. Circulation. 2000; 1.02:1773-9.

10. Welin C, Lappas G, Wilhelmsen L. Independent importance of psychosocial factors for prognosis after myocardial infarction. II Intern Med. 2000;247:629-39.

11. Irvine J, Basinski A, Baker B, Jandciu S, Paquette M, Cairns J, Connolly S, Roberts R, Gent M, Dorian P. Depression and risk of sudden cardiac death after acute myocardial infarction: testing for the confounding effects of fatigue. Psychosom Med. 1999;61:729-37.

12. Mayou RA, Gill D, Thompson DR, Day A, Hicks N, Volmink J, Neil A. Depression and anxiety as predictors of outcome after myocardial infarction. Psychosom Med. 2000;62:212-9.

13. Lane D. Carroll D, Ring C, Beevers DG, Lip GY. Effects of depression and anxiety on mortality and quality-of-life 4 months after myocardial infarction. I Psychosom Res. 2000;49:229-38.

14. Denollet J, Vaes J, Brutsaert DL. Inadequate response to treatment in coronary heart disease: adverse effects of type D personality and younger age on 5-year prognosis, and quality of life. Circulation. 2000;102:630-5.

15. Maes M, Meltzer HY. The serotonin hypothesis of major depression. New York: Raven Press; 1995.

16. Owens MJ, Nemeroff CB. Role of serotonin in the pathophysiology of depression: focus on the serotonin transporter. Clin Chem. 1994:40:288-95.

17. Staley JK, Malison RT, Innis RB. Imaging of the serotonergic system: interactions of neuroanatomical and functional abnormalities of depression. Biol Psychiatry. 1998:44:534-49.

18. Yates M, Leake A, Candy JM, Fairbairn AF, McKeith IG, Ferrier IN. SHT2 receptor changes in major depression. Biol Psychiatry. 1990;27:489-96.

19. Hrdina PD, Demeter E, Vu TB. Sotonyi P. Palkovits M. 5-HT uptake sites and 5-HT2 receptors in brain of antidepressant-free suicide victims/depressives: increase in 5-HT2 sites in cortex and amygdala. Brain Res. 1993:614:37-44.

20. Stanley M, Mann JJ. Increased serotonin-2 binding sites in frontal cortex of suicide victims. Lancet. 1983:1:214-6.

21. Mann JJ, Stanley M, McBride PA, McEwen BS. Increased serotonin2' and beta-adrenergic receptor binding in the frontal cortices of suicide victims. Arch Gen Psychiatry. 1986;43:954-9.

22. Cheetham SC, Crompton MR, Katona CL, Horton RW. Brain 5-HT2 receptor binding sites in depressed suicide victims. Brain Res. 1988:443:272-80. 
23. Stockmeier CA, Dilley GE, Shapiro LA, Overholser JC, Thompson PA, Meltzer HY. Serotonin receptors in suicide victims with major depression. Neuropsychopharmacology. 1997;16:162-73.

24. Lowther S, De Paermentier F, Crompton MR, Katona CL, Horton RW. Brain 5-HT2 receptors in suicide victims: violence of death, depression and effects of antidepressant treatment. Brain Res. 1994:642:281-9.

25. Malison RT, Price LH, Berman R, van Dyck CH, Pelton GH, Carpenter L, Sanacora G, Owens MJ, Nemeroff CB, Rajeevan N, Baldwin RM, Seibyl JP, Innis RB, Charney DS. Reduced brain serotonin transporter availability in major depression as measured by [123I]-2 beta-carbomethoxy-3 beta-(4iodophenyl)tropane and single photon emission computed tomography. Biol Psychiatry. 1998:44:1090-8.

26. Meyer JH, Kapur S, Houle S, DaSilva J, Owczarek B, Brown GM, Wilson AA, Kennedy SH. Prefrontal cortex 5-HT2 receptors in depression: an [18F]setoperone PET imaging study. Am J Psychiatry, 1999;156:1029-34.

27. Yatham LN, Liddle PF, Shiah IS, Scarrow G, Lam RW, Adam MJ, Zis AP, Ruth TJ. Brain serotonin2 receptors in major depression: a positron emission tomography study. Arch Gen Psychiatry. 2000;57:850-8.

28. Attar-Levy D, Martinot JL, Blin J, Dao-Castellana MH, Crouzel C, Mazoyer B, Poirier MF, Bourdel MC, Aymard N, Syrota A, Feline A. The cortical serotonin2 receptors studied with positronemission tomography and $[18 \mathrm{~F}]-$ setoperone during depressive illness and antidepressant treatment with clomipramine. Biol Psychiatry. 1999;45:180-6.

29. Biver F, Wikler D, Lotstra F, Damhaut P, Goldman S, Mendlewicz J. Serotonin 5-HT2 receptor imaging in major depression: focal changes in orbito-insular cortex. Br.J'Psychiatry. 1997;171:4448.

30. Mayberg HS, Robinson RG, Wong DF, Parikh R, Bolduc P, Starkstein SE, Price T, Dannals RF, Links JM, Wilson AA, Ravert HT, Wagner HN. PET imaging of cortical S2 serotonin receptors after stroke: lateralized changes and relationship to depression. Am J Psychiatry. 1988;145:937-43.

31. D'haenen H, Bossuyt A, Mertens J, Bossuyt-Piron C, Gijsemans M, Kaufman L. SPECT imaging of serotonin2 receptors in depression. Psychiatry Res. 1992;45:227-37.

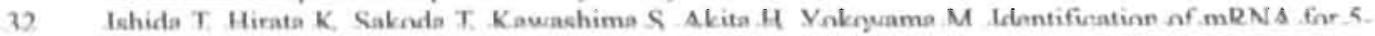
HT1 and 5-HT2 receptor subtypes in human coronary arteries. Cardiovasc Res. 1999:41:267-74.

33. Pakala R, Willerson JT, Benedict CR. Mitogenic effect of serotonin on vascular endothelial cells. Circulation. 1994:90:1919-26.

34. Willerson JT, Yao SK, MeNatt J, Benedict CR, Anderson HV, Golino P. Murphree SS, Buja LM. Frequency and severity of cyclic flow alternations and platelet aggregation predict the severity of neointimal proliferation following experimental coronary stenosis and endothelial injury. Proc Natl Acad Sci US A. 1991;88:10624-8.

35. Miyata K, Shimokawa H, Higo T, Yamawaki T, Katsumata N, Kandabashi T, Tanaka E, Takamura Y. Yogo K, Egashira K, Takeshita A. Sarpogrelate, a selective 5-HT2A serotonergic receptor antagonist, inhibits serotonin-induced coronary artery spasm in a porcine model. $J$ Cardiovasc Pharmacol. 2000;35:294-301.

36. Nilsson T, Longmore J, Shaw D, Pantev E, Bard JA, Branchek T, Edvinsson L. Characterisation of 5 -HT receptors in human coronary arteries by molecular and pharmacological techniques. Eur $J$ Pharmacol. 1999:372:49-56.

37. Rosel P. Menchon JM, Vallejo J, Arranz B, Navarro MA, Liron F, Alvarez P. Platelet $[3 \mathrm{H}]$ imipramine and [3H]paroxetine binding in depressed patients. J Affect Disord. 1997;44:79-85.

38. Rosel P. Arranz B. Vallejo J, Alvarez P. Menchon JM. Palencia T, Navarro MA. Altered $[3 \mathrm{H}]$ imipramine and $5-\mathrm{HT} 2$ but not $[3 \mathrm{H}]$ paroxetine binding sites in platelets from depressed patients. JAffect Disord. 1999:52:225-33.

39. Pandey GN, Pandey SC, Janicak PG, Marks RC, Davis JM. Platelet serotonin-2 receptor binding sites in depression and suicide. Biol Psychiatry: 1990:28:215-22.

40. Pandey GN, Pandey SC. Dwivedi Y. Sharma RP, Janicak PG, Davis JM. Platelet serotonin-2A receptors: a potential biological marker for suicidal behavior. Am J Psychiatry. 1995;152:850-5.

41. Willerson JT. Serotonin and thrombotic complications. J Cardiovase Pharmacol. 1991:17:S13-20. 
42. Vikenes K, Farstad M, Nordrehaug JE. Serotonin is associated with coronary artery disease and cardiac events. Circulation. 1999;100:483-489.

43. Schini-Kerth VB, Fisslthaler B, Van Obberghen-Schilling E, Busse R. Serotonin stimulates the expression of thrombin receptors in cultured vascular smooth muscle cells. Role of protein kinase C and protein tyrosine kinases. Circulation. 1996;93:2170-7.

44. Eckert A, Gann H, Riemann D, Aldenhoff J, Muller WE. Elevated intracellular calcium levels after 5-HT2 receptor stimulation in platelets of depressed patients. Biol Psychiatry. 1993;34:565-8.

45. Konopka LM, Cooper R, Crayton JW. Serotonin-induced increases in platelet cytosolic calcium concentration in depressed, schizophrenic, and substance abuse patients. Biol Psychiatry. 1996:39:708-13.

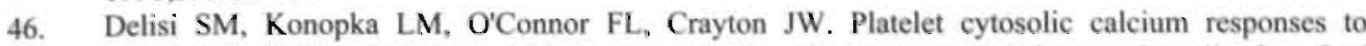
serotonin in depressed patients and controls: relationship to symptomatology and medication. Biol Psychiatry. 1998;43:327-34.

47. Mendelson SD. The current status of the platelet 5-HT(2A) receptor in depression. J Affect Disord. 2000;57:13-24.

48. von Kanel R, Mills PJ, Fainman C, Dimsdale JE. Effects of psychological stress and psychiatric disorders on blood coagulation and fibrinolysis: a biobehavioral pathway to coronary artery disease? Psychosom Med. 2001;63:531-44.

49. Gurney D, Lip GY, Blann AD. A reliable plasma marker of platelet activation: does it exist? Am J Hematol. 2002;70:139-44.

50. Suzuki K, Kusumi I, Sasaki Y, Koyama T. Serotonin-induced platelet intracellular calcium mobilization in various psychiatric disorders: is it specific to bipolar disorder? J Affect Disord. 2001;64:291-6.

51. Kusumi 1, Koyama T, Yamashita 1. Serotonin-induced platelet intracellular calcium mobilization in depressed patients. Psychopharmacology (Berl). 1994;113:322-7.

52. Bithell TC. The physiology of primary hemostasis. In: Wintrobe, ed. Wintrobe's Clinical' Hematology. London: Lea \& Febiger; 1993:540-555.

53. Gawaz M, Neumann FJ, Schomig A. Evaluation of platelet membrane glycoproteins in coronary artery disease : consequences for diagnosis and therapy. Circulation. 1999:99:EI-EII.

54. Andre P, Nannizzi-Alaimo L, Prasad SK, Phillips DR. Platelet-derived CD40L: the switch-hitting player of cardiovascular disease. Circulation. 2002;106:896-9.

55. Vanags DM, Rodgers SE, Duncan EM, Lloyd JV, Bochner F. Potentiation of ADP-induced aggregation in human platelet-rich plasma by 5-hydroxytryptamine and adrenaline. $\mathrm{Br} J$ Pharmacol. 1992; 106:917-23.

56. Vanags DM, Lloyd JV, Rodgers SE, Bochner F. ADP, adrenaline and serotonin stimulate inositol I,4,5-trisphosphate production in human platelets. Eur f' Pharmacol. 1998:358:93-100.

57. Dale GL, Friese P, Batar P, Hamilton SF, Reed GL, Jackson KW, Clemetson KJ, Alberio L. Stimulated platelets use serotonin to enhance their retention of procoagulant proteins on the cell surface. Nature. 2002;415:175-9.

58. Vanhoutte PM. Platelet-derived serotonin, the endothelium and cardiovascular disease. / Cardiovasc Pharmacol: 1991;17 (suppl. 5):S6-S12.

59. Markovitz JH, Matthews KA. Platelets and coronary heart disease: potential psychophysiologic mechanisms. Psychosom Med. 1991:53:643-68.

60. Malkoff SB, Muldoon MF, Zeigler ZR, Manuck SB. Blood platelet responsivity to acute mental stress. Psychosom Med. 1993:55:477-82'.

61. Markovitz JH, Matthews KA, Kiss, J, Smitherman TC. Effects of hostility on platelet reactivity to psychological stress in coronary heart disease patients and in healthy controls. Psychosom Med. 1996:58:143-9.

62. Markovitz JH. Hostility is associated with increased platelet activation in coronary heart disease. Psychosomatic Medicine. 1998;60:586-591.

63. Laghrissi-Thode F, Wagner WR, Pollock BG, Johnson PC, Finkel MS. Elevated platelet factor 4 and beta-thromboglobulin plasma levels in depressed patients. with ischemic heart disease. Biol Psychiatry. 1997:42:290-295. 
64. Pollock BG, Laghrissi-Thode F, Wagner WR. Evaluation of platelet activation in depressed patients with ischemic heart disease after paroxetine or nortriptyline treatment. J Clin Psychopharmacol. 2000:20:137-40.

65. Kuijpers PMJC, Hamulyak K, Strik JMH, Wellens HJJ, Honig A. Beta-thromboglobulin and platelet factor 4 levels in post myocardial infarction patients with major depression. Psychiatry Res. 2002;109:207-210.

66. Musselman DL, Tomer A, Manatunga AK, Knight BT, Porter MR, Kasey S, Marzec U, Harker LA, Nemeroff CB. Exaggerated platelet reactivity in major depression. Am J Psychiatry. 1996;153:13131317.

67. Musselman DL, Marzec UM, Manatunga A, Penna S, Reemsnyder A, Knight BT, Baron A, Hanson SR, Nemeroff CB. Platelet reactivity in depressed patients treated with paroxetine: preliminary findings. Arch Gen Psychiatry. 2000;57:875-82.

68. Markovitz JH, Shuster JL, Chitwood WS, May RS, Tolbert LC. Platelet activation in depression and effects of sertraline treatment: An open-label study. Am J Psychiatry. 2000;157:1006-8.

69. Whyte EM, Pollock BG, Wagner WR, Mulsant BH, Ferrell RE, Mazumdar S, Reynolds CF, 3rd. Influence of serotonin-transporter-linked promoter region polymorphism on platelet activation in geriatric depression. Am J Psychiatry. 2001;158:2074-6.

70. Piletz JE, Zhu H, Madakasira S, Pazzaglia P, Lindsay DeVane C, Goldman N, Halaris A. Elevated Pselectin on platelets in depression: response to bupropion. J Psychiatr Res. 2000;34:397-404.

71. Walsh MT, Dinan TG, Condren RM, Ryan M, Kenny D. Depression is associated with an increase in the expression of the platelet adhesion receptor glycoprotein Ib. Life Sci. 2002;70:3155-65.

72. Musselman DL, Marzec U, Davidoff M, Manatunga AK, Gao F, Reemsnyder A, Duggirala S, Larsen H. Taylor RW, Hanson S. Nemeroff CB. Platelet activation and secretion in patients with major depression, thoracic aortic atherosclerosis, or renal dialysis treatment. Depress Anxiety. 2002;15:91101.

73. Serebruany VL, O'Connor CM, Gurbel PA. Effect of selective serotonin reuptake inhibitors on. platelets in patients with coronary artery disease. Am J Cardiol. 2001;87:1398-400.

74. Gray JA, Roth BL. Paradoxical trafficking and regulation of 5-HT(2A) receptors by agonists and antagonists. Brain Res Bull. 2001;56:441-51.

75. Willerson JT, Eidt JF, McNatt J, Yao SK, Golino P, Anderson HV, Buja LM. Role of thromboxane and serotonin as mediators in the development of spontaneous alterations in coronary blood flow and neointimal proliferation in canine models with chronic coronary artery stenoses and endothelial injury. J Am Coll Cardiol. 1991:17:101B-110B.

76. Nugent DF, Dinan TG, Leonard BE. Further characterization of the inhibition of platelet aggregation by a plasma facior(s) in unmedicated unipolar depressed patients. Affect Disord. 1995;33:227-31.

77. McBride PA, Brown RP. DeMeo M, Keilp J, Mieczkowski T, Mann JJ. The relationship of platelet 5-HT2 receptor indices to major depressive disorder, personality traits, and suicidal behavior. Biol Psychiatry. 1994:35:295-308.

78. Maes M, Van der Planken M, Van Gastel A, Desnyder R. Blood coagulation and platelet aggregation in major depression. J Affect Disord. 1996;40:35-40.

79. Lederbogen F, Gilles M, Maras A, Hamann B, Colla M, Heuser I, Deuschle M. Increased platelet aggregability in major depression? Psychiatry Res. 2001;102:255-61.

80. Shimbo D. Child J, Davidson K, Geer E, Osende J, Reddy S, Dronge A, Fuster V, Badimon JJ. Exaggerated serotonin-mediated platelet reactivity as a possible link in depression and acute coronary syndromes. Am / Cardiol, 2002;89:331-3.

81. Karege F, Bovier P. Rudolph W, Gaillard JM. Platelet phosphoinositide signaling system: an overstimulated pathway in depression. Biol Psychiatry. 1996;39:697-702.

82. Rehavi M, Jerushalemi Z, Aviv A, Laor N, Podliszewski E, Karp L, Shavit S. Weizman R. Interaction between antidepressants and phosphoinositide signal transduction system in human platelets. Biol Psychiatry, 1993;33:40-4.

83. Stoll AL. Severus WE, Freeman MP, Rueter S, Zboyan HA, Diamond E, Cress KK, Marangell LB. Omega 3 fatty acids in bipolar disorder: a preliminary double-blind, placebo-controlled trial [see comments]. Arch Gen Psychiatry, 1999;56:407-12. 
84. Bothwell RA, Eccleston D, Marshall E. Platelet intracellular calcium in patients with recurrent affective disorders. Psychopharmacology (Berl). 1994;114:375-81.

85. Kusumi I, Koyama T, Yamashita I. Serotonin-stimulated $\mathrm{Ca} 2+$ response is increased in the blood platelets of depressed patients. Biol Psychiatry. 1991;30:310-2.

86. Mikuni M, Kagaya A, Takahashi K, Meltzer HY. Serotonin but not norepinephrine-induced calcium mobilization of platelets is enhanced in affective disorders. Psychopharmacology. 1992;106:311-4.

87. Delisi JS, Konopka LM, Russell K, O'Connor FL, Cooper R, Crayton JW. Platelet cytosolic calcium hyperresponsivity to serotonin in patients with hypertension and depressive symptoms. Biol Psychiatry. 1999:45:1035-41.

88. Dwivedi Y, Janicak PG, Pandey GN. Elevated $[3 \mathrm{H}]$ inositol 1,4,5-trisphosphate binding sites and expressed inositol 1,4,5-trisphosphate receptor protein level in platelets of depressed patients. Psychopharmacology (Berl). 1998;138:47-54.

89. Tomiyoshi R, Kamei K. Muraoka S, Muneoka K, Takigawa M. Serotonin-induced platelet intracellular $\mathrm{Ca} 2+$ responses in untrented depressed patients and imipramine responders in remission. Biol Psychiaty. 1999;45:1042-8.

90. Plein H, Berk M, Eppel S, Butkow N. Augmented platelet calcium uptake in response to serotonin stimulation in patients with major depression measured using $\mathrm{Mn} 2+$ influx and $45 \mathrm{Ca} 2+$ uptake. Life Sci. 2000:66:425-31.

91. Trip MD, Cats VM, van Capelle FJ, Vreeken J. Platelet hyperreactivity and prognosis in survivors of myocardial infarction. $N$ Engl I Med. 1990;322:1549-54.

92. Amoroso G, van Veldhuisen DJ, Tio RA, Mariani M. Pathophysiology of vascular endothelium and circulating platelets: implications for coronary revascularisation and treatment. Int $J$ Cardiol. 2001:79:265-75.

93. Du L, Bakish D, Lapierre YD, Ravindran AV, Hrdina PD. Association of polymorphism of serotonin 2A. receptor gene with suicidal ideation in major depressive disorder. Am.J Med Genet. 2000;96:5660.

94. van den Brink RHS, van Melle J, Honig A, Schene AH, Crijns HJGM, Lambert FPG, Ormel J. Treatment of depression after myocardial infarction and the effects on cardiac prognosis and quality of life: Rationale and outline of the Myocardial INfarction and Depression - Intervention Trial (MIND-IT). Am Heart J. 2002;144:219-225. 



\section{PART II}

Chapter 4

Whole blood serotonin and platelet activation in depressed post-myocardial infarction patients.

Annique Schins, Karly Hamulyák, Simon Scharpé, Richel Lousberg,

Joost Van Melle,Harry Crijns, Adriaan Honig. Submitied Life Sciences 2004 


\section{Abstract}

Background: Depression is an independent risk factor for post myocardial infarction (MI)

mortality. Abnormalities in platelet function have been proposed as one of the mechanisms involved in increased cardiovascular risk among patients with depression post-MI. Depression in somatically healthy patients has been associated with increased platelet activation. Some but not all studies showed changes in blood serotonin level. Increased platelet activation and blood serotonin level have been associated with increased risk of cardiac events in patients with MI. The goal of this study was to investigate whether 1) depressed post-MI patients have higher markers of platelet activation as measured by plasma levels of $\beta$-thromboglobulin ( $\beta$ TG), platelet factor 4 (PF4) and soluble CD40 ligand (sCD40L) and higher whole blood serotonin levels than non-depressed post-Mi patients and

2) treatment with the antidepressant mirtazapine decreases platelet activation.

Methods: 25 depressed post-MI patients were asked for blood collection before start as well as after 8 weeks treatment with mirtazapine or placebo. The control group $(n=22)$ consisted of non-depressed post-MI patients, matched for age, gender and time elapsed since MI.

Resulis: Plasma levels of $\beta T G$, PF4 and SCD40L were not statistically different between the groups, but whole blood serotonin was significantly higher in depressed patients. Treatment with mirtazapine resulted in a non-significant decrease in BTG and PF4 and an increase in serotonin levels.

Conclusions: Serotonin, but not platelet activation was significantly increased in depressed post-

MI patients. Treatment with mirtazapine showed a trend towards a decrease in platelet activation and an increase in serotonin levels. 


\section{Introduction}

Evidence is accumulating that depression is an independent risk factor for carciovascular morbidity and mortality in patients with ischaemic heart disease ${ }^{1,2}$ and individuals suffering from depression have an increased risk to develop cardiovascular heart diseases ${ }^{3}$.

Increased sensitivity to platelet activation has been postulated as one of the mechanisms that may underlie increased vulnerability of depressed post myocarcial infarction (MI) patients to cardiac events ${ }^{4}$. Platelets are anuclear organelles bestowed with receptors, which are activated by a variety of factors such as damaged endothelium, dislipidaemia and circulating substances such as thromboxane and serotonin. As far as depression is concerned, increased platelet activation as compared to controls has been assessed by measuring plasma levels of platelet-specific release products such as platelet factor $4(\mathrm{PF} 4)$ and $\beta$-thromboglobulin ( $\beta \mathrm{TG})^{\mathrm{s}}$, by measuring expression of procoagulant receptors on platelet membranes ${ }^{6,7}$ and by measuring platelet aggregation (for review ${ }^{8}$. In MI patients, platelet hyperreactivity has been associated with prediction of coronary events and mortality ${ }^{9,10}$. Recently soluble CD40 ligand (sCD40L) has been identified as another important prothrombotic and pro-inflammatory receptor on the platelet ${ }^{11,12}$, and increased levels have been related to increased cardiovascular events ${ }^{13}$. No data are available on $\mathrm{SCD} 40 \mathrm{~L}$ levels in depressed patients.

Serotonin has been shown to promote vasoconstriction ${ }^{14,15}$, thrombosis and proliferation of vascular endothelial cells ${ }^{16,17}$. Increased total blood serotonin has been associated with coronary artery disease (CAD) and subsequent cardiac events ${ }^{18}$. Data in patients with depression are less uniform: no changes, a decrease or an increase of serotonin levels have been reported in depressed patients as compared to non-depressed controls ${ }^{19-25}$.

It may be postulated that increased platelet reactivity, together with local effects of accumulation of serotonin at the atherosclerotic site may lead to increased risk of thrombo-embolic events in the post-MI period.

Selective serotonin reuptake inhibitors( SSRIs) have been demonstrated to be safe in the treatmeni of post-MI depression ${ }^{26-28}$. Along with their effect on depression, some SSRIs were shown to have an inhibitory effect on platelet activation ${ }^{29-31}$. No data are available on effects of other classes of antidepressants, such as the noradrenergic and the specific serotonergic antidepressant (NaSSA) mirtazapine.

In this study we tested the hypothesis that 1) depressed post-MI patients have increased measures of platelet activation and increased whole blood serotonin as compared to non-depressed post-MI 
patients and 2) treatment with mirtazapine $30-45 \mathrm{mg}$ results in decreased platelet activation. For this reason plasma levels of $\beta$ TG, PF4 and SCD40L and whole blood serotonin were assessed.

\section{Methods}

\section{Patients}

A consecutive cohort of 25 depressed MI patients, included in a randomised placebo controlled trial with mirtazapine (as part of their participation in the Myocardial Infarction and Depression Intervention Trial) ${ }^{32}$ were asked for blood collection. MI diagnoses were made by a cardiologist. based on to the following criteria: clinical presentation, electrocardiographic signs typical of an acute MI and enzyme aspartate aminotransferase (ASAT) levels of $\geq 80 \mathrm{U} / 1$ (twice the upper limit. of normal). Depression was defined as meeting DSM-IV criteria for major or minor depression. Patients were diagnosed with a depressive disorder following a structured Composite International Diagnostic Interview (CIDI-auto) by a research assistant as well as a clinical interview by a psychiatrist. As part of their participation in the MIND-IT study, patients could not be included earlier than 3 months and later than 12 months after MI. Intervention consisted of a double blind treatment with placebo or mirtazapine, an $\alpha_{2}$-adrenoreceptor antagonist, which also blocks 5- $\mathrm{HT}_{2}$, 5- $\mathrm{HT}_{3}$ and $\mathrm{H}_{1}$ receptors ${ }^{33}$. Because of logistic reasons, the control subjects consisted of 22 nondepressed post-MI patients matched for age, gender and period elapsed since MI. Patients with diabetes mellitus and patients receiving anticoagulant medication except aspirin were excluded for this substudy. The investigation was carried out in accordance with the latest version of the Declaration of Helsinki and the study design was approved by the local ethical committee. All participants were fully informed and gave their written informed consent.

\section{Samples}

In order to minimize in vivo platelet activation patients had to rest 15 minutes before blood collection. A venipuncture was performed after an overnight fast, applying minimal stasis, in the antecubital vein. Blood samples were collected using a 19-gauge needle and were stored in Vacutainer tubes (Becton-Dickinson, Basel, Swiss). The first $4 \mathrm{ml}$ blood was collected in ethylene diamine tetra acetic acid (EDTA) tubes to assess thrombocyte count. The next 4,5 ml were collected in tubes containing an anticoagulant and antiplatelet cocktail consisting of citric acid, theophylline, adenosine, and dipyridamole (CTAD) to minimize platelet activation in vitro. The tube was filled to capacity and gently inverted to ensure complete mixing with the anticoagulant. Samples were first centrifuged at $2000 \mathrm{~g}$ for 30 minutes at $4^{\circ}$. Blood samples for measurement of sCD 40L in plasma 
were collected in EDTA tubes (Becton-Dickinson, Basel, Swiss) and centrifuged at $2200 \mathrm{~g}$ for 5 minutes ${ }^{34}$. Whole blood for serotonin analyse was also collected in EDTA tubes. Whole blood and plasma samples were stored at $-70^{\circ}$ until analysis.

\section{Laboratory analysis}

Concentrations of BTG and PF4 were measured using commercially available, high sensitivity enzyme-linked immunoabsorbent assays (Asserachrom, Roche). Baseline plasma sCD40L concentrations were measured by ELISA (Bender medsystems BMS239MST). Briefly, plasma diluted (1:5) with diluent (diluent: 1 part human serum, 1 part BMS405) were applied in duplicate to 96-well plates (Greiner, microlon 655061) precoated with anti-human sCD40L antibody $5 \mu \mathrm{g} / \mathrm{ml}$, and mixed (1:2) with a horseradish-peroxidase-labeled secondary mouse anti-human CD40I. antibody (2 hours), 3,3'5,5'-tetramethylbenzidine was used as substrate. Color intensity was measured at $450 \mathrm{~nm}$. The detection limit of this assay was $0.160 \mathrm{ng} / \mathrm{ml}$. Whole blood for determination of serotonin was deproteinized as described ${ }^{35}$ with the exception that N-methyl-5hydroxytryptamine was used as an internal standard ${ }^{36}$. The supernatant was subjected to high performance liquid chromatography using fluorogenic detection and gradient elution ${ }^{37}$. Linearity was well beyond $10 \mu \mathrm{M}$. Within-assay $\mathrm{CV}$ was $5.3 \%$ and between-assay $\mathrm{CV}$ was $7.3 \%$.

\section{Statistical Analysis}

First, baseline characteristics were investigated of the depressed and the non-depressed groups. Chisquare in case of dichotomous variables and t-test in case of continuous variables were applied. Next, multivariate linear regression analyses were performed with serotonin levels and parameiers of platelet activation as dependent variables and post-MI depression (0-1) as predictor. Traditional cardiovascular risk factors such as smoking, body mass index (BMI), hyperiension, positive family history for CAD and cholesterol plasma levels and other possible confounders such as age, previous depressive episodes, extension of vessel disease (1,2 or three), ace-inhibitor use and calcium channel blocker use, were tested for their potential confounding effects. Cook's distance was used to identify influential cases according to the lines described by Hair et al. ${ }^{38}$. The significance level was set at $\alpha=0.05$ (two-tailed). Statistical analyses were performed with SPSS 10.0 for Windows. 
Table 1. Demographic and cardiovascular characteristics of non-depressed and depressed post-MI patients at baseline and at sampling.

\begin{tabular}{|c|c|c|c|}
\hline & $\begin{array}{l}\text { Non-depressed } \\
\text { MI-patients } \\
\mathrm{n}=22\end{array}$ & $\begin{array}{c}\text { Depressed } \\
\text { MI-patients } \\
\mathrm{n}=25\end{array}$ & $\mathrm{p}$-value \\
\hline \multicolumn{4}{|l|}{ At baseline } \\
\hline Gender $(\mathrm{m} / \mathrm{f})$ & $20 / 2$ & $23 / 2$ & NS \\
\hline Age & $54.4(10.6)$ & $55.5(10.0)$ & NS \\
\hline BMi & $27.1(3.6)$ & $26.8(4.2)$ & NS \\
\hline LVEF & $54.9(11.7)$ & $54.7(9.4)$ & NS \\
\hline $\mathrm{CK}_{\max }(\mathrm{U} / \mathrm{l})$ & $2197.9(1968.9)$ & $1906.8(1488.8)$ & NS \\
\hline $\operatorname{ASAT}_{\operatorname{man}}(\mathrm{U} / \mathrm{I})$ & $236.2(146.6)$ & $220.2(157.1)$ & NS \\
\hline Cholesterol (mg/dL) & $213.4(45.2)$ & $210.8(36.9)$ & NS \\
\hline trombolysis & $59.1 \%$ & $52.0 \%$ & NS \\
\hline PTCA & $31,8 \%$ & $40.0 \%$ & NS \\
\hline $\mathrm{CABG}$ & $18.2 \%$ & $12.0 \%$ & NS \\
\hline Smoking & $72.7 \%$ & $76.0 \%$ & NS \\
\hline Hypertension & $18.2 \%$ & $24.0 \%$ & NS \\
\hline Ventricular fibrillation & $9.1 \%$ & $4.0 \%$ & NS \\
\hline Previous MI & $4.5 \%$ & $12.0 \%$ & NS \\
\hline Peripheral vascular disease & $4.5 \%$ & $0 \%$ & NS \\
\hline \multirow[t]{3}{*}{ Vessel disease IVD } & $41.2 \%$ & $45.5 \%$ & NS \\
\hline & $23.5 \%$ & $27.3 \%$ & NS \\
\hline & $35.3 \%$ & $27.3 \%$ & NS \\
\hline CAD in family & $45.5 \%$ & $60.0 \%$ & NS \\
\hline Psychiatric disease in family & $13.6 \%$ & $12.0 \%$ & NS \\
\hline Previous depression & $4.5 \%$ & $48.0 \%$ & $<0.001$ \\
\hline \multicolumn{4}{|l|}{ At sampling } \\
\hline Months elapsed since $\mathrm{MI}$ & $6.0(2.2)$ & $5.2(2.8)$ & NS \\
\hline $\mathrm{BDI}$ & $3.5(2.7)$ & $14.1(8.0)$ & $<0.001$ \\
\hline Siopped smoking after Ml & $50.0 \%$ & $48.0 \%$ & NS \\
\hline Aspirin & $95.5 \%$ & $96.0 \%$ & NS \\
\hline Beta-blocker & $81.8 \%$ & $92.0 \%$ & NS \\
\hline Statin & $95.5 \%$ & $95.5 \%$ & NS \\
\hline ACE-inhibitor & $40.9 \%$ & $24.0 \%$ & NS \\
\hline CCB & $18.2 \%$ & $20.0 \%$ & NS \\
\hline
\end{tabular}

p-yalue $=2$-tailed level of significance; Values are means (s.d.); NS : not statistically significant; BMi: body mass index; LVEF; left ventricular ejection fraction; $\mathrm{MI}$ : myocardial infarction; $\mathrm{CK}_{\max }$ : maximum levels of creatinine kinase during hospitalisation for MI, ASA $\mathrm{T}_{\max }$ maximum levels of aspartate aminotransferase during hospitalisation for MI; PTCA: percutaneous transluminal coronary angioplasty; CABG: coronary artery bypass grafting: CAD: coronary artery disease; BDI: Beck Depression Inventory; CCB: calcium channel blocker. 


\section{Demographic data}

Patients' ages ranged from 38 to 81 (mean 55.5) in the group with a depressive disorder post-MI and from 34 to 76 (mean 54.4) in the post-MI group without depression. The difference was not significant $(\mathrm{t}=-0.4 ; \mathrm{p}=0.69)$ (Table 1). Patients started randomised treatment for depression not before 3 months post-MI, and not later than 12 months post-MI (mean $5.7 ;$ s.d.2.5). There were no significant differences between the groups with regard to $\mathrm{BMI}(\mathrm{t}=0.3 ; \mathrm{p}=0.74)$ or cholesterol plasma levels $(t=0.2 ; p=0.82)$. In the depressed group $76 \%$ smoked at the time of their infarction; $48 \%$ subsequently stopped smoking and at the time of the blood sampling only $28 \%$ still smoked. In the non-depressed group $72.7 \%$ were smokers when admitted to the hospital, $50 \%$ quit smoking and at sampling $22.7 \%$ continued smoking. The differences were not significant. Other conventional risk factors for CAD such as hypertension and CAD in the family, were not significantly different between the groups. Infarction size, as measured by left ventricle ejection fraction (LVEF), creatinine kinase (CK) and enzyme aspartate aminotransferase (ASAT) levels, were not statistically different between the groups. Treatment of $\mathrm{MI}$, defined as thrombolysis, percutaneous transluminal coronary angioplasty (PTCA) or coronary artery bypass grafting (CABG), was also not statistically different between the groups. A positive family history for psychiatric diseases was not different between the groups, but the presence of previous depressive episode(s) was significantly higher in the depressed group as compared to the non-depressed group $\left(\chi^{2}=12.5 ; p<0.001\right)$. Mean BDI score of depressed patients was 14 (s.d. 8.0) and of non-depressed patients 3.48 (s.d. 2.7); the difference was significant $(\mathrm{p}<0.001)$. Nearly all patients were prescribed aspirin $(>95 \%)$, a beta-blocker $(>$ $81 \%$ ) and a statin (>95\%). Prescription of ace-inhibitors (ACE-I) was higher in the non-depressed group as compared to the depressed group ( $40.9 \%$ vs $24 \%$ ) but the difference was not significant $(\mathrm{p}=0.13)$. Prescription of calcium channel blockers $(\mathrm{CCB})$ was also not significant between the groups $(18.2$ and $20 \%$ respectively, $\mathrm{p}=0.93)$.

\section{Results}

\section{Serotonin levels}

Whole blood serotonin (5-HT) levels were higher in depressed post-MI patients as compared to the non-depressed group (table 2). Regression analyses showed that smoking, platelet count, age, season, LVEF and CCB were significant predictors of serotonin (all p's <0.05). A multivariate regression model with 7 predictors was analysed. This resulted in a significant model $(\mathrm{F}=3.7, \mathrm{df}=$ $\left.8.43, p=0.02, R^{2}=0.41\right)$, with depression predicting serotonin $(p=0.059)$, age $(p=0.04)$ and LVEF $(\mathrm{p}=0.02)$. Based on Cook's distance we identified an outlying case in the non-depressed group, who 
had severe chronic bronchitis and who was not prescribed a beta-blocking agent. After excluding this case, the multivariate regression model was highly significant $\left(\mathrm{F}=4.9, \mathrm{df}=8.42, \mathrm{p}=0.001, \mathrm{R}^{2}=\right.$ 0.48 ), with depression significantly predicting serotonin levels with $p=0.017$ (beta 34.5 ), age with $\mathrm{p}=0.001$ (beta $=-2.6$ ), smoking $\mathrm{p}=0.042$ (beta=37.9), LVEF $\mathrm{p}=0.005$ (beta=-2), and CCB with $\mathrm{p}=$ 0.02 (beta 43). Subsequent exclusion of cases with highest Cook's distance, showed no meaningful alterations from this last model. When platelet 5-HT content was taken as dependent variable, the multivariate regression model was significant $\left(\mathrm{F}=2.9\right.$, $\mathrm{df}=7.44, \mathrm{p}=0.014, \mathrm{R}^{2}=0.32$ ), with depression predicting platelet 5-HT content with $\mathrm{p}=0.039$.

Because of 2 dropouts in week eight of the acute treatment phase, 23 depressed patients had an additional blood collection. 15 patients had received placebo and 8 had received mirtazapine. Mean baseline serotonin level $(\mathrm{ng} / \mathrm{mL})$ in the mirtazapine group was 183.8 (s.d. 56.7), and after 8 weeks treatment 212.4 (s.d. 86.3). In the placebo group mean serotonin level at baseline was 209.0 (s.d. 59.9), and after 8 weeks treatment 211.1 (s.d. 70.4). Regarding the effect of mirtazapine versus placebo, the regression model with mean serotonin level at week 8 as dependent variable, and mirtazapine/placebo $(0-1)$ and baseline serotonin level as predictors, showed a trend towards higher values for mirtazapine $(\mathrm{p}=0.057)$.

Table 2. Measurements of serotonin and parameters of platelet activation in depressed and non-depressed post-Ml patients.

\begin{tabular}{lcc}
\hline & $\begin{array}{c}\text { Non-depressed } \\
\text { Ml patients } \\
(\mathrm{n}=22)\end{array}$ & $\begin{array}{c}\text { Depressed } \\
\text { MI patients } \\
(\mathrm{n}=25)\end{array}$ \\
\hline Whole blood serotonin $(\mathrm{ng} / \mathrm{mL})$ & $180.8(59.6)$ & $203.2(59.3)^{*}$ \\
Platelet count $\left(10^{\circ} / \mathrm{L}\right)$ & $251.5(43.6)$ & $246.0(56.2)$ \\
Platelet serotonin $\left(\mathrm{nmol} / 10^{\circ}\right.$ platelets $)$ & $4.13(1.3)$ & $5.09(1.9)^{* *}$ \\
SCD $40 \mathrm{~L}(\mathrm{ng} / \mathrm{mL})$ & $0.145(0.5)^{* * *}$ & $0.150(0.8)^{* * *}$ \\
BTG $(\mathrm{IU} / \mathrm{mL})$ & $60.4(28.9)$ & $57.4(30.4)$ \\
PF4 $(\mathrm{IU} / \mathrm{mL})$ & $8.7(7.5)$ & $10.8(12.4)$ \\
\hline
\end{tabular}

- $p=0.058$, after excluding one outlying control subject, $p=0.017$

** $p=0.039$

*** all cases included (i.e. also those with values below detection limit) 


\section{Platelet activation}

Regression analysis showed that being depressed was not a predictor of $\beta$ TG levels $(p=0.74)$ or PF4 levels $(p=0.50)$. The multivariate regression model with $\beta T G$ as dependent variable and depression, platelet count and age as predictors, resulted in a significant model $\left(F=4.0, d f=3.43, p=0.01, R^{2}=\right.$ 0.22 ), with depression predicting $\beta T G$ levels with $p=0.57$ and platelet count predicting $\beta T G$ significantly with $\mathrm{p}=0.006$. The multivariate regression model with PF4 as dependent variable was not significant $\left(\mathrm{F}=1.7, \mathrm{df}=3.43, \mathrm{p}=0.18, \mathrm{R}^{2}=0.11\right.$ ), with depression predicting PF4 levels with $\mathrm{p}=0.56$ and platelet count predicting PF4 significantly with $\mathrm{p}=0.04$. Plasma $\mathrm{sCD} 40 \mathrm{~L}$ levels were below the detection limit of $0.16 \mathrm{ng} / \mathrm{mL}$ in $24 / 25$ cases from the depressed group and 19/22 cases from the non-depressed group. When all cases were included (i.e. also those with values below detection limit), mean sCD40L levels were 0.150 (s.d.0.8) for the depressed group and 0.145 (s.d. 0.5) for the non-depressed group.

Treatment effect could be analysed from a subset of 20 patients ( 8 mirtazapine and 12 placebo). Mean baseline BTG level in the mirtazapine group was 55.8 (s.d. 29.9) and after 8 weeks treatment it was 49.6 (s.d. 15.7) In the placebo group, mean baseline BTG level was 55.3 (s.d. 30.4), and after 8 weeks it was 61.0 (s.d. 25.1). For PF4 mean baseline levels for the mirtazapine group was 9.5 (s.d. 10.5), and after treatment 7.1 (s.d. 5.5) and for the placebo group 10.5 (s.d. 13.9), and after treatment 10.2 (s.d. 6.2). Although the effect in figure 1 is suggestive for a treatment effect of mirtazapine on $\beta$ TG levels, treatment effect was not significant for either $\beta T G(p=0.27)$ or PF4 $(\mathrm{p}=0.53)$.

Figure 1. Treatment effect on BTG level (mean and SE).

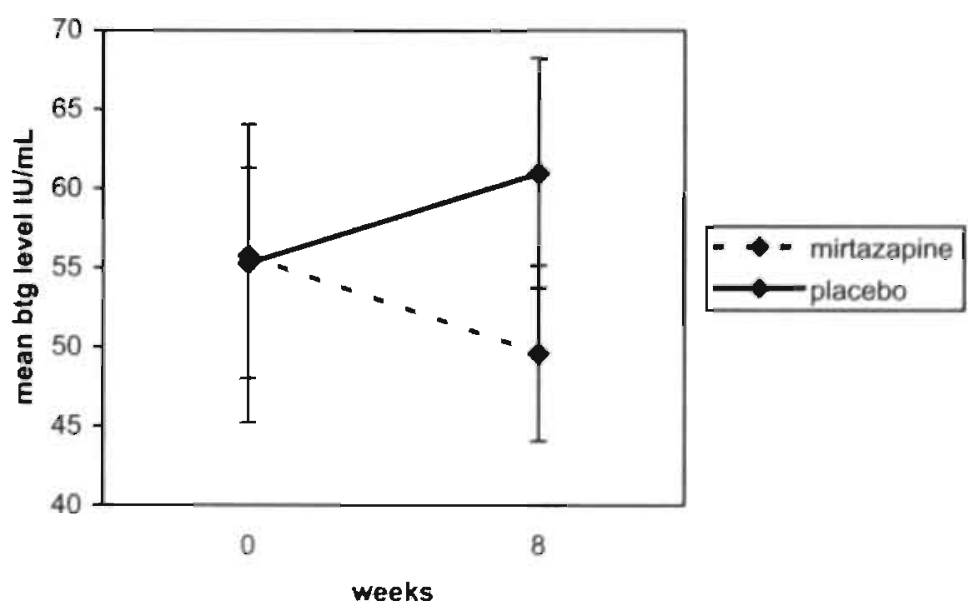




\section{Discussion}

The data from this study reveal increased total blood serotonin levels but no increase in parameters of platelet activation in MI-patients with depression as compared to MI-patients without depression. High total blood 5-HT (cut-point $175 \mathrm{ng} / \mathrm{mL}$ ) has been associated with $\mathrm{CAD}$ and subsequent cardiac events, particularly in younger age groups ${ }^{18}$. In the same study, patients with previous MI did not have higher 5 -HT levels than patients with coronary stenosis alone ${ }^{18}$, indicating that $\mathrm{MI}$ alone did not seem to account for increased levels of 5-HT. 5-HT content in platelets depends primarily on its uptake ${ }^{19}$. Because almost all 5-HT is stored inside platelets ${ }^{39}$, and because peripheral blood contains little or no free serotonin ${ }^{40}$, whole-blood analysis gives a reasonable approximation of 5IIT in platelets.

In healthy depressed subjects a decrease, an increase or no difference was found in 5-HT concentration in whole blood or platelets as compared to control subjects ${ }^{19-25}$. However, psychotic depressive patients were found to have significantly higher platelet 5-HT levels that non-psychotic depressed subjects, indicating that there may be biologically distinct subtypes of major depression ${ }^{41}$. In the present study it was postulated that depression would be associated with increased whole blood serotonin. Increased serotonin levels in depressed post-MI patients might be due to increased platelet 5-HT uptake, increased serotonin synthesis, decreased serotonin degradation or increased $\mathrm{V} / \mathrm{I}$ genotype of the serotonin-transporter-linked promoter region (SHTTLPR). Indeed, the I/I 5HTTLPR genotype has been associated with increased 5-HT transporter receptor binding and higher blood 5HT levels ${ }^{42}$. Most studies that looked at 5-HT transporter receptor in somatically healthy depressed subjects as compared to healthy controls found decreased serotonin 5-HT transporter receptors in brain and platelet membranes ${ }^{43,44}$. The finding that depressed post-MI patients showed significantly higher serotonin levels, may indicate that depression in post-Ml patients has a different underlying pathophysiological mechanism with regard to serotonin regulation than most subtypes of depression in healthy individuals. Indeed, the clinical symptomatology of depression in MI patients is different from healthy depressed ${ }^{45,46}$.

Several, but not all studies have found increased $5-\mathrm{HT}_{2 \mathrm{~A}}$ receptor binding ${ }^{47-49}$ in brain and platelets of somatically healthy depressed patients and almost invariably researchers have reported enhanced platelet responsiveness of $5-\mathrm{HT}_{2 \mathrm{~A}}$ receptors in patients with depression ${ }^{50-53}$. Serotonin-stimulated platelet activation is mediated by the $5-\mathrm{HT}_{2 \mathrm{~A}}$ receptor. Increased platelet responsiveness of $5-\mathrm{HT}_{2 \mathrm{~A}}$ receptors for serotonin might result in increased platelet activation. Data from the present. study showed however no increased platelet activation in patients with depression after MI as compared 
to patients without depression after MI. The results remained after controlling for potential confounding factors.

A possible explanation for the absence of increased platelet activation in the depressed group as compared to the non-depressed group may be medication-induced attenuation of platelet activation. Aspirin ${ }^{54}$ and beta-blockers ${ }^{55}$ have been shown to reduce platelet activation in some studies, but not in all ${ }^{56,57}$. In the present study, although more than $95 \%$ of patients were prescribed aspirin and more than $81 \%$ beta-blockers, in both depressed and non-depressed Ml patients, mean levels of BTG and PF4 in the present study were still higher than their normal reference range (10-40 and 0 $10 \mathrm{IU} / \mathrm{mL}$ respectively) and than levels reported in healthy control subjects ${ }^{4,31,58}$. A difference in BTG or PF4 levels between depressed and non-depressed could however not be detected.

Next, it has to be taken into account that parameters such as $\beta T G$ and PF4 are strongly influenced by stress ${ }^{56.57 .59}$, exercise ${ }^{60}$, phlebotomy technique, specimen anticoagulation and sample preparation ${ }^{61}$. In this study, influential factors were minimized as much as possible by using a standardized protocol regarding blood sampling, but confounding effects due to stress, phlebotomy technique and sampling procedures can not be excluded.

In this study, for the first time mean plasma levels of $\mathrm{sCD} 40 \mathrm{~L}$ were assessed in depressed post-MI patients as compared to non-depressed post-MI patients. $91.5 \%$ of samples were below detection limit after a mean period of 5.6 months after the acute event. In patients with unstable angina ${ }^{62}$ and a group of woman who subsequently developed MI, stroke or cardiovascular death ${ }^{13}$ mean sCD40L. levels were higher and predicted acute events.

Regarding the effect of antidepressant medication on platelet activation markers, sertraline and paroxetine have shown to influence platelet activation by lowering BTG and PF4 plasma levels and by decreasing pro-coagulant receptor expression on platelet membrane surface ${ }^{63} 31$. 64 . Mechanisms by which these SSRIs lower platelet activation are not clear. This pilot study is the first to assess the effect of a NaSSA on markers of platelet activation. If mirtazapine treatment in MI patients may increase serotonin levels on the one hand, it may on the other hand decrease platelet activation through platelet $5 \mathrm{HT}_{2 \mathrm{~A}}$ receptor blockade. The data showed a non-significant increase in serotonin levels and a decrease in $\beta T G$ and PF4 plasma levels in the mirtazapine treated group as compared to placebo, but sample size may have been too small to reach significance.

\section{Conclusion}

The present study shows increased serotonin levels in depressed post-MI patients as compared to non-depressed post-MI patients, but no increased platelet activation as measured by plasma levels 
of $\beta T G$, PF4 and sCD40L. If depression in post-MI patients is associated with higher serotonin levels, it might explain at least in part the association between post-MI depression and increased risk of cardiac morbidity and mortality. Regarding treatment with mirtazapine, the data warrant to study a larger sample to assess potential effects on platelet activation and whole blood serotonin levels. Prospective studies are needed to assess whether treatment of depressed post-MI patients with antidepressant medication such as mirtazapine is safe and whether treatment not only results in decrease in depressive symptoms but also in decreased post-MI cardiac morbidity and mortality.

\section{Acknowledgment}

This study was supported by grant no. 2002B207 of the "Netherlands Heart Foundation".

\section{References}

I. Barefoot JC, Schroli M. Symtomps of depression, acute myocardial infarction, and total mortality in a community sample. Circulation. 1996:93:1976-1980.

2. Bush DE, Ziegelstein RC, Tayback M, Richter D, Stevens S, Zahalsky H, Fauerbach JA. Even minimal symptoms of depression increase mortality risk after acute myocardial infarction. $\mathrm{Am} J$ Candiol. 2001;88:337-41.

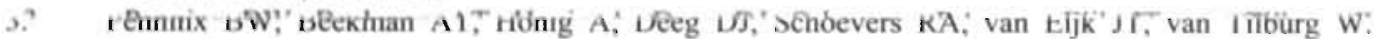
Depression and cardiac mortality: results from a community-based longitudinal study. Arch Gen Psychiatry. 2001:58:221-7.

4. Musselman DL, Tomer A, Manatunga AK, Knight BT, Porter MR, Kasey S, Marzec U, Harker LA, Nemeroff CB. Exaggerated platelet reactivity in major depression. Am J Psychiatry. 1996:153:13131317.

5. Serebruany VL, Glassman AH, Malinin AI, Sane DC, Finkel MS, Krishnan RR, Atar D, Lekht V. O'Connor CM. Enhanced platelet/endothelial activation in depressed patients with acute coronary syndromes: evidence from recent clinica! trials. Blood Coagul Fibrinolysis. 2003;14:563-7.

6. Piletz JE. Zhu H, Madakasira S, Pazzaglia P, Lindsay DeVane C, Goldman N, Halaris A. Elevated Pselectin on platelets in depression: response to bupropion. J Psychiatr Res. 2000;34:397-404.

7. Walsh MT, Dinan TG, Condren RM, Ryan M. Kenny D. Depression is associated with an increase in the expression of the platelet adhesion receptor glycoprotein Ib. Life Sci. 2002;70:3155-65.

8. Schins A, Honig A, Crijns HJGM, Baur LH, Hamulyak K. Increased coronary events in depressed cardiovascular patients: 5-HT2A receptor as missing link? Psychosom Med. 2003:65:729-737.

9. Trip MD, Cats VM, van Capelle FJ, Vreeken J. Platelet hyperreactivity and prognosis in survivors of myocardial infarction. $N$ Engl $J$ Med. 1990;322:1549-54.

10. Lioh T, Nakai K, Ono M. Hiramori K. Can the risk for acute cardiac events in acute coronary syndrome be indicated by platelet membrane activation marker P-selectin? Coron Artery Dis. 1995;6:645-50.

11. Andre P، Nannizzi-Alaimo L. Prasad SK, Phillips DR. Platelet-derived CD40L: the switch-hitting player of cardiovascular disease. Circulation. 2002;106:896-9.

12. Inwald DP, McDowall A, Peters MJ, Callard RE, Klein NJ. CD40 is constitutively expressed on platelets and provides a novel mechanism for platelet activation. Circ Res. 2003;92:1041-8.

13. Schonbeck U, Varo N, Libby P, Buring J, Ridker PM. Soluble CD40L and cardiovascular risk in women. Circulation. 2001;104:2266-8. 
14. Miyata K, Shimokawa H, Higo T, Yamawaki T, Katsumata N, Kandabashi T, Tanaka E, Takamura Y, Yogo K. Egashira K, Takeshita A. Sarpogrelate, a selective 5-HT2A serotonergic receptor antagonist, inhibits serotonin-induced coronary artery spasm in a porcine model. $J$ Cardiovase Pharmacol. 2000;35:294-301.

15. Nilsson T, Longmore J, Shaw D, Pantev E, Bard JA, Branchek T, Edvinsson L. Characterisation of 5-HT receptors in human coronary arteries by molecular and pharmacological techniques. Eur J Pharmacol. 1999;372:49-56.

16. Pakala R, Willerson JT, Benedict CR. Mitogenic effect of serotonin on vascular endothelial cells. Circulation. 1994;90:1919-26.

17. Willerson JT, Yao SK, McNatt J, Benedict CR, Anderson HV, Golino P, Murphree SS, Buja LM. Frequency and severity of cyclic flow alternations and platelet aggregation predict the severity of neointimal proliferation following experimental coronary stenosis and endothelial injury. Proc Natl Acad Sci US A. 1991;88:10624-8.

18. Vikenes $\mathrm{K}$, Farstad $\mathrm{M}$, Nordrehaug JE. Serotonin is associated with coronary artery disease and cardiac events. Circulation. 1999;100:483-489.

19. Franke L, Schewe HJ, Muller B, Campman V, Kitzrow W, Uebelhack R, Berghofer A, MullerOerlinghausen B. Serotonergic platelet variables in unmedicated patients suffering from major depression and healthy subjects: relationship between 5HT content and 5HT uptake. Life Sci. 2000;67:301-5.

20. Perez V, Bel N, Celada P, Ortiz J, Alvarez E, Artigas F. Relationship between blood serotonergic variables, melancholic traits, and response to antidepressant treatments. $J$ Clin Psychopharmacol. 1998;18:222-30.

21. Maurer-Spurej E, Pittendreigh $C$, Solomons $\mathrm{K}$. The influence of selective serotonin reuptake inhibitors on human platelet serotonin. Thromb Haemost. 2004;91:1 19-28.

22. Muck-Seler D, Jakovljevic M, Deanovic Z. Platelet serotonin in subtypes of schizophrenia and unipolar depression. Psychiatry Res, 1991;38:105-13.

23. Muck-Seler D, Jakovljevic M, Deanovic Z. Effect of antidepressant treatment on platelet 5-HT content and relation to therapeutic outcome in unipolar depressive patients. J Affect Disord. 1991;23:157-64.

24. Quintana J. Platelet serotonin and plasma tryptophan decreases in endogenous depression. Clinical, therapeutic, and biological correlations. J Affect Disord. 1992;24:55-62.

25. Le Quan-Bui KH, Plaisant O, Leboyer M, Gay C, Kamal L, Devynck MA, Meyer P. Reduced platelet serotonin in depression. Psychiatry Res. 1984;13:129-39.

26. Strik JMMH, Honig A, Lousberg R, Lousberg A, Cheriex EC, Tuynman-Qua H, Kuijpers PMJC, Wellens HJJ, Van Praag HM. Efficacy and safety of fluoxetine in the treatment of patients with major depression following first myocardial infarction: findings from a double-blind placebocontrolled trial. Psychosomatic Medicine. 2000;62:783-789.

27. Glassman AH, O'Connot CM, Califf RM, Swedberg K, Schwartz P, Bigger JT, Jr., Krishnan KR. van Zyl LT, Swenson JR, Finkel MS, Landau C, Shapiro PA, Pepine CJ, Mardekian J, Harrison WM, Barton D, McLvor M. Sertraline treatment of major depression in patients with acute MI or unstable angina. JAMA. 2002;288:701-9.

28. Berkman LF, Blumenthal J, Burg M, Carney RM, Catellier D, Cowan MJ, Czajkowski SM, DeBusk R, Hosking J, Jaffe A, Kaufmann PG, Mitchell P, Norman J, Powell LH, Raczynski JM, Schneiderman N. Effects of treating depression and low perceived social support on clinical events after myocardial infarction: the Enhancing Recovery in Coronary Heart Disease Patients (ENRICHD) Randomized Trial. Jama. 2003;289:3106-16.

29. Nair GV, Gurbel PA, O'Connor CM, Gattis WA, Murugesan SR, Serebruany VL. Depression, coronary events, platelet inhibition, and serotonin reuptake inhibitors. Am J Cardiol, 1999;84:321-3, A8.

30. Markovitz JH, Shuster JL. Chitwood. WS, May RS, Tolbert LC. Platelet activation in depression and effects of sertraline treatment: An open-label study. Am J Psychiatry. 2000;157:1006-8. 
31. Musselman DL, Marzec UM, Manatunga A, Penna S, Reemsnyder A, Knight BT, Baron A, Hanson SR, Nemeroff CB. Platelet reactivity in depressed patients treated with paroxetine: preliminary findings. Arch Gen Psychiatry. 2000;57:875-82.

32. van den Brink RHS, van Melle J, Honig A, Schene AH, Crijns HJGM, Lambert FPG, Ormel J. Treatment of depression after myocardial infarction and the effects on cardiac prognosis and quality of life: Rationale and outline of the Myocardial INfarction and Depression - Intervention Trial (MIND-IT). Am Heart J. 2002;144:219-225.

33. Anttila SA, Leinonen EV. A review of the pharmacological and clinical profile of mirtazapine. CNS Drug Rev. 2001;7:249-64.

34. Bereczki D, Nagy E, Pal A, Magyar MT, Balla J. Should soluble CD40 ligand be measured from serum or plasma samples? Arterioscler Thromb Vasc Biol. 2003;23:1129-30; author reply 1130-1.

35. Anderson GM, Young JG, Cohen DJ, Schlicht KR, Patel N. Liquid-chromatographic determination of serotonin and tryptophan in whole blood and plasma. Clin Chem. 1981;27:775-6.

36. Kumar AM, Kumar M, Deepika K, Fernandez JB, Eisdorfer C. A modified HPLC technique for simultaneous measurement of 5-hydroxytryptamine and 5-hydroxyindoleacetic acid in cerebrospinal fluid, platelet and plasma. Life Sci. 1990;47:1751-9.

37. Al Mardini H, Harrison EJ, Ince PG, Bartlett K, Record CO. Brain indoles in human hepatic encephalopathy. Heparology. 1993;17:1033-40.

38. Hair JF, ed. Multivariate data analysis. 5th ed. Upper Saddle River, New Yersey: Prentice-Hall, Inc. A Simon\&Schuster Company; 1998.

39. Humble M, Bejerot S, Bergqvist PB, Bengtsson F. Reactivity of serotonin in whole blood: relationship with drug response in obsessive-compulsive disorder. Biol Psychiatry. 2001;49:360-8.

40. Vanhoutte PM. Platelet-derived serotonin, the endothelium and cardiovascular disease. $J$ Cardiovasc Pharmacol. 1991;17 (suppl. 5):S6-S12.

41. Muck-Seler D, Jakovljevic M. Pivac N. Platelet 5-HT concentrations and suicidal behaviour in recurrent major depression. J Affect Disord.' 1996;39:73-80.

42. Hanna GL, Himle JA, Curtis GC, Koram DQ, Veenstra-VanderWeele J, Leventhal BL, Cook. EH, Jr. Serotonin transponter and seasonal variation in blood serotonin in families with obsessivecompulsive disorder. Neuropsychopharmacology. 1998:18:102-11.

43. Owens MJ. Nemeroff CB. Role of serotonin in the pathophysiology of depression: focus on the serotonin transporter. Clin Chem. 1994:40:288-95.

44. Staley JK, Malison RT, Innis RB. Imaging of the serotonergic system: interactions of neuroanatomical and functional abnormalities of depression. Biol Psychiatry. 1998;44:534-49.

45. Honig A, Lousberg R, Wojehiechowski F, Cheriex EC, Weltens H, Van Praag HM. Depression. following a first myocardial infarction; similarities with and difference from 'ordinary' depression (Depressie na een eerste hartinfarct: overeenkomsten en verschillen met een gewone depressie). Ned Tijdschr Geneeskunde. 1997:14 1:196-199.

46. Sirik J. Honig A. Lousberg R, van Os J, van den Berg EJ. van Praag HM. Clinical correlates of depression following myocardial infarction. Int J Psychiatry Med. 2001;31:255-64.

47. Mayberg HS, Robinson RG, Wong DF, Parikh R, Bolduc P, Starkstein SE, Price T, Dannals RF, Links JM, Wilson AA. Ravert HT, Wagner HN. PET imaging of cortical S2 serotonin receptors after stroke: lateralized changes and relationship to depression. Am J Psychiatry. 1988;145:937-43.

48. D'haenen H. Bossuyt A. Mertens J, Bossuyt-Piron C, Gijsemans M, Kaufman L. SPECT imaging of serotonin2 receptors in depression. Psychiatry Res. 1992;45:227-37.

49. Pandey GN. Pandey SC. Dwivedi Y, Sharma RP, Janicak PG, Davis JM. Platelet serotonin-2A receptors: a potential biological marker for suicidal behavior. Am J Psychiatry. 1995;152:850-5.

50. Eckert A, Gann H, Riemann D, Aldenhoff J, Muller WE. Elevated intracellular calcium levels after 5-HT2 receptor stimulation in platelets of depressed patients. Biol' Psychiatry. 1993;34:565-8.

51. Konopka LM. Cooper R. Crayton JW. Serotonin-induced increases in platelet cytosolic calcium concentration in depressed, schizophrenic, and substance abuse patients. Biol Psychiatry. 1996:39:708-13. 
52. Delisi SM, Konopka LM, O'Connor FL, Crayton JW. Platelet cytosolic calcium responses to serotonin in depressed patients and controls: relationship to symptomatology and medication. Biol Psychiatry. 1998:43:327-34.

53. Mendelson SD. The current status of the platelet 5-HT(2A) receptor in depression. $J$ Affect Disord. 2000:57:13-24.

54. Gavaghan TP, Hickie JB. Krilis SA, Baron DW, Gebski V, Low J, Chesterman CN. Increased plasma beta-thromboglobulin in patients with coronary artery vein graft occlusion: response to low dose aspirin. J Am Coll Cardiol. 1990;15:1250-8.

55. Mehta J, Mehta P. Effects of propranolol therapy on platelet release and prostaglandin generation in patients with coronary heart disease. Circulation. 1982;66:1294-9.

56. Levine SP, Towell BL, Suarez AM, Knieriem LK, Harris MM, George JN. Platelet activation and secretion associated with emotional stress. Circulation. 1985;71:1129-34.

57. Markovitz JH, Matthews KA, Kiss J, Smitherman TC. Effects of hostility on platelet reactivity to psychological stress in coronary heart disease patients and in healthy controls. Psychosom Med. 1996;58:1413-9.

58. Laghrissi-Thode F, Wagner WR, Pollock BG, Johnson PC. Finkel MS. Elevated platelet factor 4 and beta-thromboglobulin plasma levels in depressed patients with ischemic heart disease. Biol Psychiatry. 1997;42:290-295.

59. Malkoff SB, Muldoon MF, Zeigler ZR, Manuck SB. Blood platelet responsivity to acute mental stress. Psychosom Med. 1993;55:477-82.

60. Stratton JR, Malpass TW, Ritchie JL, Pfeifer MA, Harker LA. Studies of platelet factor 4 and beta thromboglobulin release during exercise: lack of relationship to myocardial ischemia. Circulation. 1982;66:33-43.

61. Gurney D, Lip GY, Blann AD. A reliable plasma marker of platelet activation: does it exist? Am $J$ Hematol. 2002;70:139-44.

62. Aukrust P, Muller F, Ueland T, Berget T, Aaser E, Brunsvig A, Solum NO, Forfang K, Froland SS, Gullestad L. Enhanced levels of soluble and membrane-bound CD40 ligand in patients with unstable angina. Possible reflection of T lymphocyte and platelet involvement in the pathogenesis of acute coronary syndromes. Circulation. 1999;100:614-20.

63. Serebruany VL, Glassman AH, Malinin AI, Nemeroff CB, Musselman DL, van Zyl LT, Finkel MS, Krishnan KR, Gaffney M, Harrison W, Califf RM, O'Connor CM. Platelet/endothelial biomarkers in depressed patients treated with the selective serotonin reuptake inhibitor sertraline after acute coronary events: the Sertraline AntiDepressant Heart Attack Randomized Trial (SADHART) Platelet Substudy. Circulation. 2003;108:939-44.

64. Pollock BG, Laghrissi-Thode $\mathrm{F}$, Wagner WR. Evaluation of platelet activation in depressed patients with ischemic heart disease after paroxetine or noririptyline treatment. I Clin Psychopharmacol. 2000;20:137-40. 



\section{PART III}

Chapter 5

Increased cerebral 5- $\mathrm{HT}_{2 \mathrm{~A}}$ receptor binding in depressed post myocardial infarction patients.

Annique Schins, Marinus van Kroonenburgh, Koen Van Laere, Hugo D'haenen, Richel Lousberg, Harry Crijns,

Jos Eersels, Adriaan Honig.

Submitted Biol Psych 2004 


\section{Abstract}

Background: Serotonin is implicated in the pathophysiology of depression. It is not known whether depression in post-myocardial infarction (MI) patients is also serotonin mediated. Increased brain $5-\mathrm{HT}_{2 \mathrm{~A}}$ receptor binding has been found in somatically healthy depressed subjects. Animal studies have shown decreased serotonin activity after MI. In the present study it was hypothesized that depressed post-MI patients would exhibit increased brain 5$\mathrm{HT}_{2 \mathrm{~A}}$ receptor binding as compared to non-depressed post-MI patients and no a priori hypothesis was formulated with regard to $5-\mathrm{HT}_{2 \mathrm{~A}}$ receptor binding in $\mathrm{MI}$ patients as compared to control subjects.

Methods: $\quad$ 5- $\mathrm{HT}_{2 \mathrm{~A}}$ receptor binding was studied by means of single photon emission computed tomography (SPECT) using the radioligand ${ }^{12} \mathrm{I}-5-\mathrm{I}-\mathrm{R} 91150$, a $5-\mathrm{HT}_{2 \mathrm{~A}}$ receptor antagonist. SPECT scans were performed in 9 depressed post-MI patients, 10 non-depressed post-MI patients and 10 healthy control subjects, matched for age and gender. Results were analysed using statistical parametric mapping.

Results: Depressed post-MI patients showed increased right frontal 5- $\mathrm{HT}_{2 \mathrm{~A}}$ receptor binding as compared to non-depressed post-MI patients ( $\mathrm{p}_{\text {cluters }}<0.001$ ). This finding was more pronounced in patients with previous depressive episodes. Non-depressed post-MI patients showed decreased $5-\mathrm{HT}_{2 \mathrm{~A}}$ receptor binding in right and left frontal regions as compared to control subjects.

Conclusions: Depression post-MI is associated with increased $5-\mathrm{HT}_{2 \mathrm{~A}}$ receptor binding as compared to non-depressed post-MI patients whereas patients with MI have decreased 5$\mathrm{HT}_{2 \mathrm{~A}}$ receptor binding compared to age-matched healthy controls. 


\section{Introduction}

It is well documented that serotonin (5-HT) is implicated in the pathophysiology of depression ! Regarding 5- $\mathrm{HT}_{2 \mathrm{~A}}$ receptors, post-mortem brain studies showed both an increase in $5-\mathrm{HT}_{2 \mathrm{~A}}$ receptors in the brain of depressed suicide victims ${ }^{2-5}$ or no difference ${ }^{6-8}$. Two in vivo brain studies looking at $5-\mathrm{HT}_{2 \mathrm{~A}}$ receptor binding in somatically healthy depressed patients as compared to age matched healthy controls measured increased binding ${ }^{9,10}$, but data are not uniform ${ }^{11,12}$. At the same time, depression has also been associated with increased platelet $5-\mathrm{HT}_{2 \mathrm{~A}}$ receptor binding ${ }^{13-15}$ and platelet $5-\mathrm{HT}_{2 \mathrm{~A}}$ receptors are similar in pharmacologic and biochemical characteristics to $5-\mathrm{HT}_{2 \mathrm{~A}}$ receptors in the brain. No data are yet available on brain $5-\mathrm{HT}_{2 \mathrm{~A}}$ receptor binding in physically compromised depressive patients, in particular depressed post myocardial infarction (MI) patients. Depression post-MI has a different presentation as depression in somatically healthy patients, as the cognitive profile and clinical features such as listlessness and irritability are more pronounced in depressed post-MI patients ${ }^{16}$; also therapeutical outcome shows an atypical response to pharmacological treatment ${ }^{17,18}$. Diminution of 5-HT metabolism with compensatory upregulation of $5-\mathrm{HT}_{1 \mathrm{~A}}$ and $5-\mathrm{HT}_{2 \mathrm{~A}}$ receptors has been postulated in anxiety/aggression-driven depression ${ }^{19}$.

We hypothesized that post-Ml patients with depression would exhibit increased $5-\mathrm{HT}_{2 \mathrm{~A}}$ receptor binding as compared to non-depressed post-MI patients, but no a priori hypothesis was formulated with regard to $5-\mathrm{HT}_{2 \mathrm{~A}}$ receptor binding in MI patients as compared to control subjects. For this purpose central 5- $\mathrm{HT}_{2 \mathrm{~A}}$ receptor binding was assessed in depressed and non-depressed post-MI patients and age matched healthy controls using single photon emission computer tomography (SPECT).

\section{Methods}

9 depressed and 10 non-depressed MI patients were recruited in a collaborative setting of the departments of Psychiatry and Cardiology of the Academical Hospital of Maastricht in The Netherlands. 10 healthy control subjects were matched with the MI patients for sex and age and were recruited from an existing bank of volunteer subjects from the Maastricht Institute for Brain and Behaviour. MI diagnoses were made by a cardiologist according to the following criteria: clinical presentation, electrocardiographic signs typical of an acute MI and enzyme aspartate aminotransferase (ASAT) levels of $\geq 80 \mathrm{U} / 1$ (twice the upper limit of normal). Depression was defined as minor or major depressive episode according to Structured Clinical Interview for DSM= IV (SCID-L/P version 2.0) and a minimal Hamilton Depression Rating Scale (HAMD-17) of 10. MI patients also filled out the depression subscale of the 90-item Symptom Check List (SCL-90). The. 
diagnosis was confirmed by a psychiatrist. The period between MI and SPECT ranged from 4 - 20 months post-MI. All subjects were naive of antipsychotic and antidepressant medication for at least 2 years before the SPECT procedure. Exclusion criteria for the SPECT study were a past history of severe head trauma with unconsciousness, other co-morbid brain pathology, either primary or induced such as secondary to chronic alcohol abuse, use of antidepressant medication or $5 \mathrm{HT}_{2 \mathrm{~A}}$ blocking agents.

The study was approved by the hospital's committee on medical ethics and written informed consent was obtained from all participants.

\section{SPECT procedure}

\section{Radionuclide synthesis and injection}

SPECT images were obtained using the radioligand ${ }^{123}$ I-5-I-R91150 with high affinity $\left(\mathrm{K}_{\mathrm{d}}=0.11\right.$. $+/-0.01 \mathrm{nM})$ and high selectivity for the $5-\mathrm{HT}_{2 \mathrm{~A}}$ receptor. The selectivity of this ligand for $5 \mathrm{HT}_{2 \mathrm{~A}}$ as compared to other neurotransmitter receptor binding sites such as 5- $\mathrm{HT}_{1 \mathrm{~A}}, 5-\mathrm{HT}_{1 \mathrm{~B}}, 5-\mathrm{HT}_{1 \mathrm{D}}, 5-$ $\mathrm{HT}_{2} \mathrm{C}, 5 \mathrm{HT}_{3}$ dopamine, adrenoreceptors and histamine $(\mathrm{H} 1)$ is at least a factor $50{ }^{20} \cdot{ }^{123} \mathrm{I}-\mathrm{R} 91150$ (4-amino-N-[1-[3-(4-fluorophenoxy)propyl]-4-methyl-4-piperidinyl]-5-iodo-2-methoxybenzamide) was produced by the Radionuclide Center, Free University (Amsterdam, The Netherlands), and was synthesised by electrophilic substitution on the 5-position of the methoxybenzamide group of R91150, followed by purification with high-performance liquid chromatography. The specific activity of the labelled compound was $370 \mathrm{GBq} / \mu \mathrm{mol}$ while the radiochemical purity of the final product was more than $98 \%$. Thyroid was blocked by drinking a Lugol's solution containing 400 mg potassium iodide 15 minutes prior to the study for all subjects. The average administered radioligand activity was $185 \mathrm{MBq}(5 \mathrm{mCi})$ and was injected as a single bolus over a 30 second period followed by $10 \mathrm{ml}$ saline.

\section{Image acquisition and reconstruction}

Subjects were scanned on a triple-headed gamma camera (Siemens, Chicago, USA) equipped with parallel-hole collimators (measured spatial resolution $7 \mathrm{~mm}$ ). Since previoụ work using sequential dynamic acquisition has shown that the cortico-cerebellar ratio reaches pseudo-equilibrium between 90 and $110 \mathrm{~min}$ postinjection and remains stable thereafter for up to $4 \mathrm{~h}$, the acquisition was started between 110 and $140 \mathrm{~min}$ after tracer injection ${ }^{21}$. Emission images were acquired in a $128 \times 128$ matrix with 90 projections dụring $40 \mathrm{~min}$. No scatter correction was applied. Images were 
reconstructed by means of filtered backprojection (Butterworth filter; cut-off frequency of 0.3 cycles $/ \mathrm{cm}$ and order 10 ).

\section{Spatial normalisation}

Before analysis, images were spatially transformed to stereotactic co-ordinates ${ }^{22}$. Pre-processing of the reconstructed images was performed to allow automatic detailed anatomical standardization. In a first step, the original reconstruction data were converted to Interfile 3.3 format and extracerebral activity was removed by a masking procedure: using the Brass software (Nuclear Dingnostics, Hägersted, Sweden). This masking procedure is necessary as the tracer bas a high and interindividually variable aspecific uptake in the scalp and oronasopharynx that hampers automated coregistration of the individual $5 \mathrm{HT}_{2 \mathrm{~A}}$ images.

Anatomical standardisation and subsequent statistical parametric mapping analysis was done using statistical parametric mapping (SPM99) ${ }^{23,24}$. The pre-processed data were converted into ANALYZE format using MedCon conversion software v 0.8 .7 (http://xmedcon.sourceforge.net). All SPM calculations were performed on the Matlab 5.3 platform (Mathworks Inc., Sherborn, MA, USA).

An anatomically standardised serotonin template with this radioligand was constructed based upon previous work using 12 young healthy volunteers ${ }^{25}$. Anatomical standardization of this template was achieved in SPM99 by using the same transformation parameters as the coregistered ${ }^{90 \mathrm{~m}} \mathrm{Tc}$ ECD perfusion template ${ }^{26}$. The latter was transformed to the sterectactic MNI (Montreal Neurological Institute) SPECT template in SPM99 using non-linear transformations with $2 \times 3 \times 2$ basis functions and bilinear interpolation. The resultant voxel size after normalisation was set to $2 \times 2 \times 2 \mathrm{~mm}$.

On this template in MNI space, all individual subject images were anatomically coregistered using linear affine transformations.

\section{Creation of binding potential maps and statistical parametric analysis}

As a measure for the binding potential, the activity per voxel divided by the activity per voxel in the cerebellum (presumed void of $5-\mathrm{HT}_{2 \mathrm{~A}}$ receptors) was taken. In this way, parametric maps of binding potential were created by dividing all images with the mean cerebellar volume of interest (VOI) count.

Before group comparisons and further statistical analysis in SPM, all subject data were smoothed to account for gyral variations between individuals and to increase the signal-to-noise ratio. An 
isotropic Gaussian kernel of $8 \mathrm{~mm}$ was used. No proportional scaling or scaling of the grand mean was used as the images represent binding potential maps. The default grey matter threshold of 0.80 was used to identify grey matter.

\section{Data analysis}

Statistical analysis of the imaging data was performed using SPM99 ${ }^{23.24}$. SPM99 combines the general linear model to create the statistical map, and random field theory to make statistical inferences about regional effects ${ }^{24,27}$. Linear contrasts were used to test the hypotheses for specific focal effects. The resulting set of voxel values for each contrast constitutes an SPM of the t statistic SPM $\{t\}$. The SPM $\{t\}$ maps were thresholded at $\mathrm{pheight} \leq 0.05$. To correct for multiple comparisons, clusters of voxels that survived this threshold were assessed further using the random Gaussians fields theory, which calculated the significance of clusters based on their peak height and spatial extent. Finally, these clusters of voxels were visualised using glass brain representations with projections along the major axes to indicate the brain regions which exhibited significant changes.

Differences between groups were studied in a categorical population-comparison design with 1 scan/subject (2-sample t-test). To extend the SPM analysis we also performed a regression analysis for the correfation between depression scores (as measured by HAMD and SCL-D scores) and 5$\mathrm{HT}_{2 \mathrm{~A}}$ receptor binding, with age as covariate. To optimise sensitivity, the regression analyses was performed with previously defined volumes of interest (VOIs) which included the regions identified by SPM in the group comparison design (i.e. right superior frontal, right prelateral frontal and right lateral frontal VOls). This was performed on a personal computer using the Statistical Package for Social Sciences (SPSS) software, version 10.0 (SPSS10.0).

To evaluate the location of significant clusters, the MNI co-ordinates were transformed into Talairach co-ordinates and probable anatomical locations by means of the Talairach Daemon software (Research Imaging Centre, University of Texas Health Science Center, San Antonio http://ric.uthscsa.edu/projects/talairachdaemon.html ). 
Table 1. Characteristics of (depressed) MI patients and controls subjects

\begin{tabular}{|c|c|c|c|}
\hline Clinical data & $\begin{array}{l}\text { MI and depression } \\
\qquad(\mathrm{n}=9)\end{array}$ & $\begin{array}{c}\text { MI } \\
(\mathrm{n}=10)\end{array}$ & $\begin{array}{l}\text { Controls } \\
(\mathrm{n}=10)\end{array}$ \\
\hline Gender M/F & $7 / 2$ & $9 / 1$ & $8 / 2$ \\
\hline Age (years) & $49.44(6.85)$ & $51.90(8.20)$ & $50.10(9.88)$ \\
\hline Months post-MI & $7.72(3.35)$ & $9.55(4.86)$ & - \\
\hline $\mathrm{CK}_{\max }(\mathrm{U} / 1)$ & $2261(1587)$ & $2344(1761)$ & - \\
\hline $\operatorname{ASAT}_{\max }(\mathrm{U} / \mathrm{l})$ & $262(194)$ & $275(179)$ & - \\
\hline LVEF (\%) & $54(6.38)$ & $51(10.25)$ & - \\
\hline HAMD-17 score & $15.78(3.83)^{*}$ & $3.42(2.95)$ & $1.81(1.75)$ \\
\hline SCL-D score & $26.78(7.53)^{*}$ & $17.40(1.51)$ & $17.89(2.98)$ \\
\hline $\begin{array}{l}\text { Antidepressant drug free } \\
\text { period }\end{array}$ & $>2$ years & - & - \\
\hline $\begin{array}{l}\text { Previous depressive episodes } \\
(y / n)\end{array}$ & $4 / 5$ & $0 / 10$ & - \\
\hline Aspirin / Acenocoumarol & 9 & $7 / 3$ & - \\
\hline Beta-blocker & 9 & I0 & - \\
\hline Statin & 9 & 10 & - \\
\hline Ace-inhibitors & 2 & 3 & - \\
\hline Calcium channel blocker & 0 & 3 & - \\
\hline
\end{tabular}

Values are means (s.d.). HAMD-17: 17-item Hamilton rating scale for depression; SCL-D score: depression subscale of the SCL-90; $\mathrm{CK}_{\max }$ : maximum levels of creatinine kinase during hospitalisation for ML; ASAT $_{\max }$ maximum levels of aspartate aminotransferase during hospitalisation for Ml; LVEF: left ventricle ejection fraction

* $\mathrm{P}<0.006$

\section{Results}

Demographic data

$19 \mathrm{MI}$ patients and 10 control subjects were inciuded in the study. Patients" ages ranged from 40 to 62 in the group with a depressive disorder post-MI, 40 to 63 in the post-MI group without depression, and 39 to 64 in the control group (Table 1). There was no significant difference in age $\left(F_{29}=0.37 ; p=0.69\right)$ or gender $\left(\chi^{2}=0.39 ; p=0.82\right)$ between the 3 groups. The period between index MI and SPECT scan ranged from 4-13 months (mean 7.72, s.d. 3.35) in the depressed post-MI group and 5-20 (mean 9.55, s.d. 4.86) in the non-depressed post-MI group. As a measure of severity of MI, left ventricular ejection fraction (LVEF), maximal creatinine kinase (CK) and maximal 
aspartate aminotransferase (ASAT) levels were taken. As can be seen in table 1, depressed MI patients had somewhat higher mean LVEF and lower mean ASAT and CK levels, indicating a less severe MI, but differences were not significant. The mean HAMD score for depressed post-MI patients was 15.78 (range from 10-24), non-depressed post-MI 3.42 (range 0-7) and controls 1.81 (range 0-6). The difference between the groups was significant $(\mathrm{p}<0.0001)$. There were no significant differences in cardiac medication in the MI group (table 1). Control subjects did not use medication.

\section{5-HT $2 A$ receptor binding}

Comparing depressed post-MI patients and non-depressed post-MI patients, SPM 99 analysis showed two significant clusters (cluster size 8752, peorrected $<0.0001$ ) with increased $5-\mathrm{HT}_{2 \mathrm{~A}}$ receptor binding in depressed post-MI patients in right medial frontal and right inferior frontal cortical regions (figure 1 and table 2). When depressed post-MI patients were compared to healthy control subjects, no significant clusters were found ( $p_{\text {corrected }}>0.9$ ). When non-depressed MI patients were compared to age-matched healthy controls, three significant clusters (cluster size 6804, Pcorrected $=0.001$ ) with decreased $5-\mathrm{HT}_{2 \mathrm{~A}}$ receptor binding were noted in non-depressed $\mathrm{MI}$ patients in both right and left frontal cortical regions (table 2).

In a post-hoc analysis increased $5-\mathrm{HT}_{2 \mathrm{~A}}$ receptor binding in patients with previous depressive episodes $(n=4)$ was found (cluster size $=3103$ and $\left.p_{\text {corrected }}=0.051\right)$ as compared to patients who had never experienced depression $(\mathrm{n}=5)$. Also post-hoc correlations between $5 \mathrm{HT}_{2 \mathrm{~A}}$ receptor binding in MI patients $(\mathrm{n}=19)$ and sympioms of depression as measured by HAMD or SCL-D scores were investigated. Regression analyses adjusting for age were performed with three VOls which were more close to the regions identified by SPM in the group comparison design, i.e. right superior frontal, right prelateral frontal and right lateral frontal VOi. A positive correlation of SCL-D with $5 \mathrm{HT}_{2 \mathrm{~A}}$ receptor binding in the right superior frontal VOI (Pearson's $\mathrm{r}=0.42, \mathrm{p}=0.074$ ) was found. After excluding one outlying case based on Cook's distance, the correlation was significant (Pearson's $r=0.552, p=0.018)$, and remained significant $(\mathrm{p}=0.024)$ after correcting for age as covariate. A positive correlation of $\mathrm{HAMD}$ sores with $5 \mathrm{HT}_{2 \mathrm{~A}}$ receptor binding in the right superior frontal VOI became only significant after exclusion of a second outlying case based on Cook's distance $\left(\mathrm{p}=0.03\right.$ ). No significant correlations were found between $5 \mathrm{HT}_{2 \mathrm{~A}}$ receptor binding in right prelateral frontal or right lateral frontal VOIs and SCL-D or HAMD scores. Correlations were no longer significant after correcting for multiple VOI comparisons. 
Table 2. Cluster size, $\mathrm{p}$ values, $\mathrm{T}$ values, and coordinates of clusters of A) depressed MI patients with increased 5- $\mathrm{HT}_{2 \mathrm{~A}}$ receptor binding as compared to non-depressed $\mathrm{Ml}$ patients and $\mathrm{B}$ ) non-depressed MI patients with decreased $5-\mathrm{HT}_{2 \mathrm{~A}}$ receptor binding as compared to control subjects.

\begin{tabular}{|c|c|c|c|c|c|c|c|c|c|}
\hline & \multicolumn{2}{|c|}{ Cluster } & \multicolumn{5}{|l|}{ Voxels } & & \multirow[t]{3}{*}{ Brain region } \\
\hline & \multirow[t]{2}{*}{ Size } & \multirow{2}{*}{$\begin{array}{l}\text { Corrected } \\
\text { p-value }\end{array}$} & \multirow[t]{2}{*}{$\mathrm{T}$ value } & \multirow{2}{*}{$\begin{array}{l}\text { Corrected } \\
\text { Pheight- } \\
\text { value }\end{array}$} & \multirow{2}{*}{$\begin{array}{l}\text { Uncorrected } \\
\text { Pheight -value }\end{array}$} & \multicolumn{3}{|c|}{ Coordinates } & \\
\hline & & & & & & $\mathrm{x}$ & $\mathrm{Y}$ & Z & \\
\hline \multirow[t]{2}{*}{ A } & 8752 & 0.000 & 4.66 & 0.571 & 0.000 & 10 & -24 & 58 & $\begin{array}{l}\text { Right medial frontal } \\
\text { gyrus }\end{array}$ \\
\hline & & & 4.57 & 0.622 & 0.000 & 38 & 4 & 30 & $\begin{array}{l}\text { Right inferior } \\
\text { frontal gyrus }\end{array}$ \\
\hline \multirow[t]{3}{*}{ B } & 6804 & 0.001 & 3.78 & 0.965 & 0.001 & 12 & -24 & 60 & $\begin{array}{l}\text { Right medial frontal } \\
\text { gyrus }\end{array}$ \\
\hline & & & 3.40 & 0.997 & 0.002 & -60 & 20 & 25 & $\begin{array}{l}\text { Left medial frontal } \\
\text { gyrus }\end{array}$ \\
\hline & & & 3.15 & 0.999 & 0.003 & -50 & 50 & 15 & $\begin{array}{l}\text { Left inferior frontal } \\
\text { gyrus }\end{array}$ \\
\hline
\end{tabular}

Figure 1. Projections illustrate regions of increased 5-HT $2 \mathrm{~A}$ receptor binding in depressed post-MI patients as compared to non-depressed post-M1 patients on a sagittal rendering of the brain. Voxels are included for which $Z$ exceeds 1.72 (see cover page).

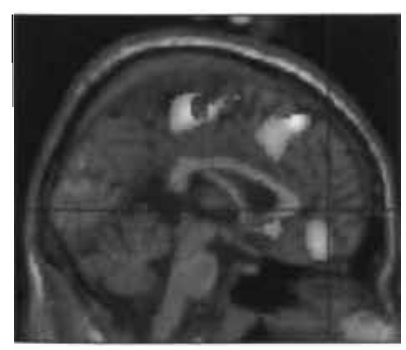

\section{Discussion}

This is the first study to assess $5-\mathrm{HT}_{2 \mathrm{~A}}$ receptor binding in post-Ml patients. Significant increases of $5-\mathrm{HT}_{2 \mathrm{~A}}$ receptor binding in right frontal brain regions in depressed post-MI patients as compared to non-depressed post-MI patients were found. In contrast comparing non-depressed MI patients and 
controls, a decreased $5-\mathrm{HT}_{2 \mathrm{~A}}$ receptor binding was noted in non-depressed $\mathrm{MI}$ patients in right and left frontal cortical regions.

Regarding serotonin neurotransmission, there is evidence from in vivo brain imaging studies that depression is associated with decreased 5-HT transporters ${ }^{28}$. Data on $5-\mathrm{HT}_{1 \mathrm{~A}}$ receptors are inconclusive, because of paucity of selective radiotracers for the $5-\mathrm{HT}_{1 \mathrm{~A}}$ receptor subtype. Reports on 5- $\mathrm{HT}_{2 \mathrm{~A}}$ receptor binding are not uniform: some studies measured increased binding ${ }^{9,10}$, two detected decreased binding ${ }^{12,29}$, and four reported no difference ${ }^{11,30-32}$ in 5- $\mathrm{HT}_{2 \mathrm{~A}}$ receptor binding comparing depressed patients with control subjects. Several factors however should be taken into account when interpreting results of above mentioned studies. First, different ligands to bind the 5$\mathrm{HT}_{2 \mathrm{~A}}$ receptor were used and different techniques to analyse data. Second, different age groups have been studied such as patients 60 years or more ${ }^{32}$ and it has been shown that $5-\mathrm{HT}_{2 \mathrm{~A}}$ receptor binding decreases with age ${ }^{20}$. Third, in some studies use of psychotropic medications such as benzodiazepines were allowed, which have been shown to upregulate $5-\mathrm{HT}_{2 \mathrm{~A}}$ binding sites ${ }^{33}$. Also, a different drug-free period of antidepressant medication was allowed. In some studies a drug free period of 2 weeks was admitted, while in others it was six months ".

In order to minimize influence of confounding factors, in the present study groups were matched for age and gender. Next, use of cardiac medication was not significantly different among Ml patients. Nearly all patients received aspirin, except three patients in the non-depressed group who received acenocoumarol. All MI patients used a statin and were prescribed metoprolol, a lipophilic betablocker. The beta-1-adrenergic receptor is present in the brain and alterations in the density and/or sensitivity of beta-1-adrenergic receptors have been reported in depression. Lipophilic beta-blockers have been shown, both in animals and man, to readily cross the blood-brain barrier in contrast to hydrophilic beta-blockers ${ }^{34}$. This feature is not necessarily synonymous with the ability to cause central nervous system effects. Up to date, findings regarding the association of depressive symptoms and beta-blockers are still equivocal ${ }^{35}$. Regarding statins, calcium channel blockers and ace inhibitors, no direct effects have been reported on central serotonin receptors ${ }^{36.37}$. Nevertheless, an influential effect of cardiovascular treatment regimens in the present study cannot be excluded. Regarding use of psychotropic medication, in the present study depressed patients were more than two years free of previous antidepressant treatment and used no other psychotropic drugs. A confounding effect of psychotropic medications is therefore highly improbable.

In a recent antidepressant intervention study in depressed patients with recent $\mathrm{MI}$ or unstable angina, significant changes of HAMD scores in the treatment group as compared to the placebo group were only found in a subgroup of patients with previous depressive episodes ${ }^{18}$. And in MI 
patients with a prior history of depression, depression is more likely to develop and to persist after MI ${ }^{18}$. If both conditions (depression post-MI with or without prior history of depression) are different subtypes of depression, differences in $5-\mathrm{HT}_{2 \mathrm{~A}}$ receptor binding might be postulated. Unfortunately, only a few of previously mentioned 5- $\mathrm{HT}_{2 \mathrm{~A}}$ imaging studies reported occurrence of previous depressive episodes ${ }^{12,29.38}$ and no data are available on differences in $5-\mathrm{HT}_{2 \mathrm{~A}}$ binding patterns between the two conditions. In the present study, 4 of the 9 depressed post-MI patients reported a previous depressive episode. Increased $5-\mathrm{HT}_{2 \mathrm{~A}}$ receptor binding in patients with previous depressive episodes as compared to the group who had never experienced depression was found. Although this finding relates to a small group, nonetheless it suggests more pronounced central 5$\mathrm{HT}_{2 \mathrm{~A}}$ receptor binding changes in patients with recurrent depression.

Regarding receptor binding studies in depressed patients without somatic co-morbidity, it is not clear whether central 5-HT receptor changes are causally related to depression. Because of the cross-sectional design of the present study, it is not possible to draw conclusions about the time of occurrence of changes in $5-\mathrm{HT}_{2 \mathrm{~A}}$ receptor status. It has been postulated that decreased 5-HT (leading to upregulation of central $5-\mathrm{HT}_{2 \mathrm{~A}}$ receptors) is one of the mechanisms that could lead to depression ${ }^{10}$ and once a patient has developed depression, failure to downregulate $5-\mathrm{HT}_{2 \mathrm{~A}}$ receptors has been postulated to play a key role in relapse of depression ${ }^{39}$. Regarding the present data, it might be hypothesized that depressed post-MI patients had less down-regulation of $5-\mathrm{HT}_{2 \mathrm{~A}}$ receptors in contrast to $\mathrm{MI}$ patients who were not clinically depressed.

In animal studies inhibition of brain serotonergic activity was shown after $\mathrm{MI}^{40}$. After MI the body has to has to restore damaged tissue. Adaptive mechanisms have to be regulated in order not to overshoot and prove detrimental. In the present study, the non-depressed MI patients were found to have decreased $5-\mathrm{HT}_{2 \mathrm{~A}}$ receptor binding as compared to age maiched healthy controls. It can be postulated that while depressed post-MI patients were not able to down-regulate $5-\mathrm{HT}_{2 \mathrm{~A}}$ recepiors, MI patients were able to downregulate central $5-\mathrm{HT}_{2 \Lambda}$ receptors, but there might be an overshooting effect, resulting in even lower binding than controls. Another possibility is that adaptive mechanisms after MI lead to decreased 5- $\mathrm{HT}_{2 \mathrm{~A}}$ receptors. Finally, because in this study the control group had no cardiovascular medications, a confounding effect of cardiovascular treatment regimens on central $5-\mathrm{HT}_{2 \mathrm{~A}}$ receptors cannot be excluded.

Limitations of the present study are that results are based on a relatively small number of patients. Relevant clusters were therefore present at fairly low thresholds and differences between groups did not survive more conservative thresholds for spatial locations. It is therefore not possible on the basis of the present results to spatially localize the differences found more exactly. Extended studies 
with higher statistical power are needed to localize the differences more clearly. Moreover, longitudinal studies may shed more light on the dynamic relation between depression in post-MI patients and serotonergic abnormalities.

\section{Acknowledgment}

The authors like to thank Sandra Rosmuller, Pieter Kubben and Walter Backes for their great help during data collection and processing.

\section{References}

1. Maes M, Meltzer HY. The serotonin hypothesis of major depression. New York: Raven Press; 1995.

2. Yates M, Leake A, Candy JM, Fairbairn AF, McKeith IG, Ferrier IN. 5HT2 receptor changes in major depression. Biol Psychiatry. 1990;27:489-96.

3. Hrdina PD, Demeter E, Vu TB, Sotonyi P, Palkovits M. 5-HT uptake sites and 5-HT2 receptors in brain of antidepressant-free suicide victims/depressives: increase in 5-HT2 sites in cortex and amygdala. Brain Res, 1993;614:37-44.

4. Stanley M, Mann JJ. Increased serotonin-2 binding sites in frontal cortex of suicide victims. Lancet. $1983 ; 1: 214-6$.

5. Mann JJ, Stanley M, McBride PA, McEwen BS. Increased serotonin2 and beta-adrenergic receptor binding in the frontal cortices of suicide victims. Arch Gen Psychiatry, 1986;43:954-9.

6. Cheetham SC, Crompton MR, Katona CL. Horton RW. Brain 5-HT2 receptor binding sites in depressed suicide victims. Brain Res. 1988:443:272-80.

7. Stockmeier CA, Dilley GE, Shapiro LA, Overholser JC, Thompson PA, Meltzer HY. Serotonin receptors in suicide victims with major depression. Neuropsychopharmacology: 1997;16:162-73.

8. Lowther S, De Paermentier F, Crompton MR, Katona CL. Horton RW. Brain 5-HT2 receptors in suicide victims: violence of death, depression and effects of antidepressant treatment. Brain Res. 1994:642:281-9.

9. D'haenen H, Bossuyt A, Mertens J, Bossuyt-Piron C, Gijsemans M, Kaufman L. SPECT imaging of serotonin 2 receptors in depression. Psychiatry Res. 1992;45:227-37.

10. Meyer IH, MeMain S, Kennedy SH, Korman L, Brown GM, DaSilva JN, Wilson AA, Blak T, Eynan-Harvey R, Goulding VS. Houle S, Links P. Dysfunctional attitudes and 5-HT2 receptors during depression and self- harm. Am J Psychiatry. 2003;160:90-9.

11. Meyer JH, Kapur S, Houle S, DaSilva J, Owczarek B. Brown GM, Wilson AA, Kennedy SH. Prefrontal cortex 5-HT2 receptors in depression: an [18F]setoperone PET imaging study. $\mathrm{Am} J$ Psychiatry. 1999:156:1029-34.

12. Yatham LN, Liddie PF, Shiah IS, Scarrow G, Lam RW, Adam MJ, Zis AP, Ruth TJ. Brain serotonin2 receptors in major depression: a positron emission tomography study. Arch Gen Psychiatry, 2000;57:850-8.

13. Pandey GN, Pandey SC, Janicak PG, Marks RC, Davis JM. Platelet serotonin-2 receptor binding sites in depression and suicide. Biol Psychiatry: 1990;28:215-22.

14. Pandey GN, Pandey SC, Dwivedi Y, Sharma RP, Janicak PG, Davis JM. Platelet serotonin-2A receptors: a potential biological marker for suicidal behavior. Am J Psychiatry. 1995;152:850-5.

15. Rosel P. Arranz B, Vallejo J. Alvarez P. Menchon JM. Palencia. T, Navarro MA. Altered $[3 \mathrm{H}]$ imipramine and $5-\mathrm{HT} 2$ but not $[3 \mathrm{H}]$ paroxetine binding sites in platelets from depressed patients. J.Affect Disord. 1999:52:225-33.

16. Dijkstra JB, Strik JJ, Lousberg R, Prickaerts J, Riedel WJ, Jolles J, van Praag HM, Honig A. Atypical cognitive profile in patients with depression after myocardial infarction. $J$ Affect Disord. 2002:70:181-90. 
17. Strik JJMH, Honig A, Lousberg R. Lousberg A, Cheriex EC, Tuynman-Qua H, Kuijpers PMJC, Wellens HJJ, Van Praag HM. Efficacy and safety of fluoxetine in the treatment of patients with major depression following first myocardial infarction: findings from a double-blind placebocontrolled trial. Psychosomatic Medicine. 2000;62:783-789.

18. Glassman AH, O'Connor CM, Califf RM, Swedberg K, Schwartz P, Bigger JT, Jr., Krishnan KR, van Zyl LT, Swenson JR, Finkel MS, Landau C, Shapiro PA, Pepine CJ, Mardekian J, Harrison WM, Barton D. McLvor M. Sertraline treatment of major depression in patients with acute MI or unstable angina. JAMA. 2002;288:701-9.

19. Van Praag HM. Anxiety/aggression--driven depression. A paradigm of functionalization and verticalization of psychiatric diagnosis. Prog Neuropsychopharmacol Biol Psychiatry. 2001;25:893924.

20. Baeken C, D'Haenen H, Flamen P, Mertens J, Terriere D, Chavatte K, Boumon R, Bossuyt A. 123I5-I-R91150, a new single-photon emission tomography ligand for 5- HT2A receptors: influence of age and gender in healthy subjects. Eur J Nucl Med. 1998;25:1617-22.

21. Busatto GF, Pilowsky LS, Costa DC, Mertens J, Terriere D, EII PJ, Mulligan R, Travis MJ, Leysen JE, Lui D, Gacinovic S, Waddington W, Lingford-Hughes A, Kerwin RW. Initial evaluation of 123I5-I-R91150, a selective 5-HT2A ligand for single-photon emission tomography, in healthy human subjects. Eur J Nucl Med. 1997:24:119-24.

22. Talairach J, Toumoux P. Co-Planar Stereotactic Atlas of the Human Brain. Stuttgart, Germany: Thieme Medical Publishers: 1988.

23. Friston KJ, Ashburner J, Frith CD, Poline JB, Heather JD, Frackowiak RSJ. Spatial registration and normalisation of images. Human Brain Map. 1995;2:165-189.

24. Friston KJ, Holmes A, Poline JB, Price CJ, Frith CD. Detecting activations in PET and AMRI: levels of inference and power. Neuroimage. 1996;4:223-35.

25. Audenaert K, Van Laere K, Dumont F, Slegers G, Mertens J, van Heeringen C, Dierckx RA. Decreased frontal serotonin 5-HT 2a receptor binding index in deliberate self-harm patients. Eur $J$ Nucl Med. 2001;28:175-82.

26. Van Laere K, Koole M, D'Asseler Y, Versijpt J, Audenaert K, Dumont F, Dierckx. R. Automated stereotactic standardization of brain SPECT receptor data using single-photon transmission images. $J$ Nucl Med. 2001:42:361-75.

27. Worsley KJ. Local maxima and the expected Euler characteristic of excursion sets of X2, F and $\mathrm{T}$ fields. Adv Appl Probability. 1994;26:13-42.

28. Malison RT, Price LH, Berman R, van Dyck CH, Pelton GH, Carpenter L, Sanacora G, Owens M., Nemeroff CB, Rajeevan N. Baldwin RM, Seibyl JP. Innis RB, Chamey DS. Reduced brain serotonin transporter availability in major depression as measured by [123i]-2 beta-carbomethoxy-3 beta- 4 . iodophenyl)tropane and single photon emission computed tomography. Biol Psychiatry. 1998:44:1090-8.

29. Biver F, Wikler D, Lotstra F, Damhaut P, Goldman S, Mendlewicz J. Serotonin 5-HT2 receptor imaging in major depression: focal changes in orbito-insular cortex. $\mathrm{Br}$ J Psychiatry. 1997:171:4448.

30. Attar-Levy D, Martinot JL, Blin J, Dao-Castellana MH, Crouzel C, Mazoyer B. Poirier MF, Bourdel MC, Aymard N, Syrota A, Feline A. The cortical serotonin2 receptors studied with positronemisssion tomography and [18F]-setoperone during depressive illness and antidepressant treatmen: with clomipramine. Biol Psychiatry. 1999;45:180-6.

31. Meyer JH, Kapur S, Eisfeld B, Brown GM, Houle S, DaSilva J, Wilson AA, Rafi-Tari S, Mayberg HS, Kennedy SH. The effect of paroxetine on 5-HT(2A) receptors in depression: an [(18)F]setoperone PET imaging study. Am \& Psychiatry. 2001;158:78-85.

32. Meltzer CC, Price JC, Mathis CA, Greer PJ, Cantwell MN, Houck PR, Mulsant BH, Ben-Eliezer D, Lopresti B, DeKosky ST, Reynolds CF, 3rd. PET imaging of serotonin type $2 \mathrm{~A}$ receptors in late-life neuropsychiatric disorders. Am J Psychiatry. 1999;156:1871-8.

33. Wagner HR, Reches A, Yablonskaya E, Fahn S. Clonazepam-induced up-regulation of serotonin I and serotonin2 binding sites in rat frontal cortex. Adv Neurol. 1986;43:645-51. 
34. McAinsh J, Cruickshank JM. Beta-blockers and central nervous system side effects. Pharmacol Ther. 1990;46:163-97.

35. Bright RA, Everitt DE. Beta-blockers and depression. Evidence against an association. Jama. 1992:267:1783-7.

36. Smith MT, Cabot PJ, Ross FB, Robertson AD, Lewis RJ. The novel N-type calcium channel blocker, AM336, produces potent dose-dependent antinociception after intrathecal dosing in rats and inhibits. substance $\mathrm{P}$ release in rat spinal cord slices. Pain. 2002;96:119-27.

37. Friehe H, Ney P. Pharmacological and toxicological studies of the new angiotensin converting enzyme inhibitor moexipril hydrochloride. Arzneimittelforschung. 1997;47:132-44.

38. Yatham LN, Liddle PF, Dennie J, Shiah IS, Adam MJ, Lane CJ, Lam RW, Ruth TJ. Decrease in brain serotonin 2 receptor binding in patients with major depression following desipramine treatment: a positron emission tomography study with fluorine-18-labeled setoperone. Arch Gen Psychiatry, 1999;56:705-11.

39. Yatham LN, Liddle PF, Shiah IS, Lam RW, Adam MJ, Zis AP, Ruth TJ. Effects of rapid tryptophan. depletion on brain 5-HT(2) receptors: a PET study. Br.J Psychiatry. 2001;178:448-53.

40. Sole MJ, Versteeg DH, de Kloet ER, Hussain N, Lixfeld W. The identification of specific serotonergic nuclei inhibited by cardiac vagal afferents during acute myocardial ischemia in the rat. Brain Res. 1983;265:55-61. 


\section{PART IV}

Chapter $\mathbf{6}$

Inflammatory markers in depressed post myocardial infarction patients.

Annique Schins, Dorien Tulner, Richel Lousberg, Gunter Kenis, Joris Delanghe, Harry Crijns, Gert Grauls, Frank Stassen, Michael Maes, Adriaan Honig. Submitted'J Psych Res 2004 


\section{Abstract}

Background: Depressive disorder in the post-myocardial infarction (MI) period has been associated with increased cardiac morbidity and mortality. Possible pathophysiological mechanisms behind this association are not clear. Major depression in physically healthy subjects has been related to immune abnormalities including increased plasma levels of interleukin-6 (IL-6), tumor necrosis factor alfa (TNF- $\alpha$ ) and C-reactive protein (CRP). In patients with MI, increased inflammatory markers, such as CRP and TNF- $\alpha$, have been associated with increased cardiovascular events. It was the aim of this study to test the hypothesis that depression in post-MI patients is associated with increased inflammation as compared to non-depressed post-MI patients.

Methods: The cytokines IL-6 and TNF- $\alpha$; the soluble cytokine receptors sIL-6R, STNF-RI and sTNF-RII; neopterin; and the inflammation-sensitive plasma proteins (ISPs) CRP and haptoglobin were assessed in a group of 57 patients with a diagnosis of depression post-MI and in a control group of 46 non-depressed post-MI patients, matched for age, gender and time elapsed since MI.

Results: Cytokine, neopterin and ISP levels were not statistically different in the depressed post-MI group as compared to the non-depressed post-MI group. Several inflammatory markers were however considerably elevated in both cohoris when compared with levels reported in healihy subjects, indicating persistent inflammation several months after MI.

Conclusions: There was no indication of increased inflammation in depressed post-MI patients as compared to non-depressed post-MI patients.

\section{Introduction}

Depression is an important independent risk factor for cardiovascular events in both medically healthy individuals and cardiac patients ${ }^{1,2}$. Possible pathophysiological mechanisms behind this association have not yet been elucidated. interestingly, in somatically healthy patients with major depression, increased levels of cytokines, such as IL-1 $\beta$, IL-2, IL6 and TNF- $\alpha$, have been reported ${ }^{3-}$ ". Also, increased levels of neopterin and inflammation-sensitive plasma proteins (ISPs) such as CRP and haptoglobin have been found ${ }^{10-13}$.

On the other hand, growing evidence suggests that atherosclerosis, as one of the main causes of cardiovascular events, is fundamentally an inflammatory disease ${ }^{14}$ and that inflammatory markers are predictors of coronary events ${ }^{15,16}$. In patients with MI, a major clinical complication of atherosclerosis, increased levels of TNF- $\alpha^{15}$ and CRP ${ }^{16}$ were associated with increased risk of 
recurrent coronary events. And in a prospective study involving 14916 apparently healthy men, elevated levels of IL-6 were associated with increased risk of future MI ${ }^{17}$. Recently neopterin, which is produced by activated macrophages and serves as a marker for the activation status of monocytes/macrophages, was shown to be a predictor of adverse coronary events in patients who experienced a non-Q-wave $\mathrm{MI}^{\text {is }}$.

In summary, recent evidence suggests that both depression as well as atheroselerosis-associated diseases such as MI, are characterized by elevated levels of various circulating proinflammatory mediators. Some of these proinflammatory markers have additionally been associated with increased risk of cardiac events. If both $\mathrm{MI}$ and depression are associated with inflammation, it may be hypothesized that depressed post-MI patients have an additional inflammation on top of MIrelated inflammation. Higher levels of proinflammatory mediators, which are at the same time risk markers for coronary artery disease (CAD), might then be a possible link between post-MI depression and increased cardiac morbidity and mortality. In this study we tested the hypothesis that depressed post-MI patients have increased markers of inflammation as compared to non-depressed post-MI patients. For this reason cytokines IL-6 and TNF- $\alpha$; soluble cytokine receptors sIL-6R, sTNF-RI and sTNF-RII; neopterin and the ISPS CRP and haptoglobin were assessed in depressed and non-depressed post-MI patients.

\section{Patients and methods}

A consecutive cohort of 57 depressed MI patients were recruited from September 2001 to December 2002. All patients included filled in a 2l-item Beck Depression Inventory (BDI) questionnaire as part of their participation in the multicenter Myocardial Infarction and Depression - Intervention Trial (MIND-IT) ${ }^{19}$. MI diagnoses were made by a cardiologist based on to the following criteria: clinical presentation, electrocardiographic signs typical of an acute MI and enzyme aspartate aminotransferase (ASAT) levels of $\geq 80 \mathrm{U} / \mathrm{I}$ (twice the upper limit of normal).

Depression was defined as meeting DSM-IV criteria for major or minor depression. Patients were diagnosed with a depressive disorder following a structured Composite International Diagnostic Interview (CIDI-auto) by a research assistant as well as a clinical interview by a psychiatrist. Patients were diagnosed for depression not before 3 months post-MI, and not later than 12 months post-MI (mean 6.0; s.d 3.3). Because of logistic reasons, the control group consisted of 46 nondepressed post-MI patients, matched for age, gender, center and time elapsed since. MI. Blood samples were taken between 9.00 and 11.00 a.m. after an overnight fast. A venapuncture was performed in the antecubital vein. Blood samples were collected and stored in sterile Vacutainer 
tubes without additives (Becton-Dickinson, Basel, Swiss) and samples centrifuged at 2200g for 5 minutes. Serum samples were stored at $-70^{\circ}$ until analysis. Exclusion criteria for this substudy were: presence of other psychiatric diagnoses, receiving anticoagulant medication except aspirin, presence of acute infections and presence of chronic illnesses known to affect the immune status (e.g. rheumatoid arthritis, inflammatory bowel disease). The investigation was carried out in accordance with the latest version of the Declaration of Helsinki and the study design was approved by the local ethical committee. All participants were fully informed and gave written informed consent.

\section{Laboratory analyses}

Serum concentrations of various inflammatory markers were measured using commercially available enzyme-linked immunosorbent assays (ELISA). Kits for sIL-6R, TNF- $\alpha$, sTNF-Ri and sTNF-RII were obtained from Bender MedSystems (Vienna, Austria), and kits for neopterin from IBL (Hamburg, Germany). CRP was measured using a high-sensitive ELISA-kit from ICN Pharmaceuticals (Orangeburg, NY, USA). All assays were performed according manufacturer instructions. The detection limits in our laboratory were: $0.08 \mathrm{ng} / \mathrm{ml}$ (sIL-6R, sTNF-R $60 \mathrm{kDa}$ ), 0.16 $\mathrm{ng} / \mathrm{ml}$ (sTNF-R $80 \mathrm{kDa}), 8 \mathrm{pg} / \mathrm{ml}(\mathrm{TNF}-\alpha$ ) and $0.005 \mathrm{mg} / \mathrm{L}$ (CRP). IL-6 concentrations were measured with ELISA-kits from DiaMed-Eurogen (Turnhout, Belgium) using a modified protocol to increase the sensitivity of the ELISA. Modifications were: longer incubation times for standard/sample and detection-antibody incubation ( $2 \mathrm{~h}$ and $1 \mathrm{~h}$, respectively); incubation of standard/sample and detection-antibody at room temperature while shaking at $600 \mathrm{rpm}$ on a microtiterplate shaker; and further dilution of standards. The detection limit in our laboratory was $0.5 \mathrm{pg} / \mathrm{ml}$. Hp concentrations were determined by means of fixed-time immunonephelometry with a BN II nephelometer (Behringwerke AG, Marburg, Germany), calibrated against the international CRM 470 standards ${ }^{20}$.

\section{Statistical Analysis}

First, baseline characteristics were investigated of the depressed and the non-depressed groups. Chisquare in case of dichotomous variables and t-test in case of continuous variables were applied. Next, multivariate linear regression analyses were performed with each individual immune parameter as dependent variables and post-MI depression (0-I) as predictor. Age, smoking on admission, dummy variables for quit smoking after MI, continue smoking after MI and never smoked, body mass index (BMI), hypertension, positive family history for CAD, months elapsed since MI and cholesterol plasma levels were tested for their potential confounding effects. Since it 
was a multicenter study, it was tested whether there were in-between center effects. Analyses were also performed with (a continuous) mean BDI score as predictor instead of (a dichotomous) depressive state. Cook's distance was used to identify influential cases according to the lines described by Hair et al. ${ }^{21}$. The significance level was set at $\alpha=0.05$ (two-tailed). Statistical analyses were performed with SPSS 10.0 for Windows.

Table 1. Demographic and cardiovascular characteristics of depressed and non-depressed post-MI patients on admission to hospital for $\mathrm{Ml}$ and at discharge.

\begin{tabular}{|c|c|c|c|}
\hline & $\begin{array}{c}\text { Non-depressed } \\
\text { MI-patients } \\
(n=46)\end{array}$ & $\begin{array}{c}\text { Depressed } \\
\text { Ml-patients } \\
(\mathrm{n}=57)\end{array}$ & p-value \\
\hline Gender $(\mathrm{m} / \mathrm{f})$ & $41 / 5$ & $49 / 8$ & NS \\
\hline Age & $56.1(12.0)$ & $57.3(11.1)$ & NS \\
\hline BMI & $26.7(3.7)$ & $27.0(4.2)$ & NS \\
\hline $\mathrm{CK}_{\max }(\mathrm{U} / \mathrm{A})$ & $1995(1897)$ & $1895(1735)$ & NS \\
\hline $\mathrm{ASAT}_{\max }(\mathrm{U} / \mathrm{l})$ & $239(157)$ & $226(169)$ & NS \\
\hline Cholesterol $(\mathrm{mmol} / \mathrm{L})$ & $5.3(1.1)$ & $5.3(1.1)$ & NS \\
\hline Smoking on admission (\%) & 65.2 & 61.4 & NS \\
\hline Hypertension $(\%)$ & 21.7 & 22.8 & NS \\
\hline Diabetes mellitus (\%) & 6.5 & 7.0 & NS \\
\hline Previous MI (\%) & 4.4 & 8.8 & NS \\
\hline Peripheral vascular disease $(\%)$ & 10.9 & 7.0 & NS \\
\hline \multicolumn{4}{|l|}{ At discharge } \\
\hline Trombolysis ( $\%$ ) & 43.5 & 38.6 & NS \\
\hline PTCA $(\%)$ & 45.7 & 42.1 & NS \\
\hline $\mathrm{CABG}(\%)$ & 6.5 & 5.3 & NS \\
\hline \multirow{4}{*}{$\begin{array}{cc}\text { LVEF }(\%) \quad \geq 60 \% \\
\\
\\
45-60 \% \\
30-45 \% \\
<30 \%\end{array}$} & 31.8 & 13.2 & NS \\
\hline & 38.6 & 50.9 & NS \\
\hline & 27.3 & 26.4 & NS \\
\hline & 2.3 & 9.4 & NS \\
\hline Aspirin $(\%)$ & 95.7 & 89.5 & NS \\
\hline Beta-blocker ( $\%)$ & 84.8 & 87.7 & NS \\
\hline Statin $(\%)$ & 82.6 & 91.2 & NS \\
\hline ACE-inhibitor $(\%)$ & 34.8 & 24.6 & NS \\
\hline Calcium antagonist (\%) & 15.2 & 21.1 & NS \\
\hline
\end{tabular}

p-value $=2$-tailed level of significance; Values are means (s.d.); NS : not statistically significant; BMI: body mass. index; LVEF: left ventricular ejection fraction; MI: myocardial infarction; $\mathrm{CK}_{\max }$ : maximum levels of creatinine kinase during hospitalisation for Ml, ASAT $\operatorname{man}$ maximum levels of aspartate aminotransferase during hospitalisation for MI; PTCA: percutaneous transluminal coronary angioplasty; $C A B G$ : coronary artery bypass grafting; $C A D$ : coronary artery disease; BDI: Beck: Depression Inventory.

\section{Results}

Demographic data

Patients' ages ranged from 36 to 79 (mean 57.3) in the group with a depressive disorder post-MI and from 34 to 80 (mean 56.1) in the post-MI group without depression. As part of their 
participation in the MIND-IT study, patients could not be included earlier than 3 months after MI and not later than 12 months post-MI (mean 5.8; s.d 3.3). Mean BDI score of depressed patients was 13.5 (s.d. 6.8) and of non-depressed patients 3.4 (s.d. 2.4); the difference was significant $(\mathrm{p}<0.001)$. There were no significant differences between the groups with regard to BMI $(t=-0.3 ; p$ $=0.7$ ) or cholesterol plasma levels $(t=-0.1 ; p=0.9)$ (table 1). Other conventional risk factors for CAD such as hypertension, smoking and CAD in the family were not significantly different between the groups. Infarction size, as measured by left ventricle ejection fraction (LVEF), creatinine kinase (CK) and enzyme aspartate aminotransferase (ASAT) levels were not statistically different between the groups. Treatment of MI, defined as thrombolysis, percutaneous transluminal coronary angioplasty (PTCA) or coronary artery bypass grafting (CABG), was also not statistically different between the groups. Nearly all patients were prescribed aspirin ( $>89 \%$ ), a beta-blocker ( $>$ $84 \%$ ) and a statin (> 82\%). Prescription of ace-inhibitors (ACE-1) was higher in the non-depressed group as compared to the depressed group ( $35 \%$ and $25 \%$ respectively) but the difference was not significant. Prescription of calcium channel blockers (CCB) was $15 \%$ and $21 \%$ respectively $(\mathrm{p}=$ $0.6)$.

Tab!e 2. Inflammatory markers (mean, SD) in depressed and non-depressed post-MI patients.

\begin{tabular}{lccc}
\hline & $\begin{array}{c}\text { Non-depressed } \\
\text { post-MI patients } \\
(\mathrm{n}=46)\end{array}$ & $\begin{array}{c}\text { Depressed post- } \\
\text { MI patients } \\
(\mathrm{n}=57)\end{array}$ & p-value \\
\hline sTNF-R2 $(\mathrm{ng} / \mathrm{mL})$ & $12.7(11.0)$ & $15.3(13.0)$ & $\mathrm{NS}$ \\
sTNF-RI $(\mathrm{ng} / \mathrm{mL})$ & $0.96(0.4)$ & $0.89(0.4)$ & $\mathrm{NS}$ \\
TNFa $(\mathrm{pg} / \mathrm{mL})$ & $38.2(8.3)$ & $38.1(9.5)$ & $\mathrm{NS}$ \\
II-6 $(\mathrm{pg} / \mathrm{mL})$ & $1.96(1.6)$ & $2.2(2.5)$ & $\mathrm{NS}$ \\
sIl-6R $(\mathrm{ng} / \mathrm{mL})$ & $230(81.3)$ & $213(90.9)$ & $\mathrm{NS}$ \\
hsCRP $(\mathrm{mg} / \mathrm{L})$ & $3.3(3.2)$ & $3.8(4.3)$ & $\mathrm{NS}$ \\
neopterine $(\mathrm{nmol} / \mathrm{L})$ & $6.4(2.3)$ & $7.4(2.6)$ & $\mathrm{NS}$ \\
haptoglobine $(\mathrm{g} / \mathrm{L})^{*}$ & $1.7(0.7)$ & $1.5(0.7)$ & $\mathrm{NS}$ \\
\hline
\end{tabular}

* haptoglobin was assessed in a sample of 33 depressed and 23 non-depressed post-MI patients

\section{Immune activation}

Data from this study showed no meaningful increased immune activation in depressed post-MI patients as compared to matched non-depressed post-MI patients for any cytokine or cytokine receptor (all p's > 0.29). After controlling for potential confounders, the multivariate regression models for each cytokine and cytokine receptor remained non-significant. 
There was a trend towards significance for higher neopterin levels in the depressed post-MI group: the model was significant $\left(\mathrm{F}=4.5, \mathrm{df}=2.96, \mathrm{p}=0.013, \mathrm{R}^{2}=0.09\right)$, with depression predicting neopterin levels with $p=0.053(\beta=0.97)$ and smoking on admission with $p=0.027(\beta=-1.1)$. High sensitive (hs) CRP and haptoglobin were not significantly different between the groups ( $\mathrm{p}$ 's $>0.39$ ). The differences remained non-significant after correcting for confounding factors.

In post-hoc analyses, smoking on admission to hospital predicted sTNF-RII $(p=0.002, \beta=-7.8)$ and quit smoking after MI predicted sTNF-RI $(p=0.045, \beta=-2.3)$. After excluding three outliers based on Cook's distance, quit smoking predicted CRP levels with $p=0.03(\beta=-1.8)$ and still smoking after MI with $p=0.012(\beta=2.2)$. A positive family history for CAD was a significant predictor for sTNF-RI $(p=0.04, \beta=-0.2)$. Time elapsed since MI was a significant predictor for both sTNF-RII $(\mathrm{p}=0.03, \beta=0.9)$ and sTNF-RI $(\mathrm{p}=0.03, \beta=0.03)$.

When BDI score was used as predictor instead of depressive state, no significant association of depression scores with any cytokine, cytokine receptor or ISP was found. A significant model was found with neopterin as dependent variable $\left(F=6.1, \mathrm{df}=2.94, \mathrm{p}=0.003, \mathrm{R}^{2}=0.11\right)$ with $\mathrm{BDI}$ score significantly predicting neopterin levels $(p=0.01, \beta=0.09)$ as well as smoking on admission $(p=$ $0.01, \beta=-1.4)$.

\section{Discussion}

Both depressed and MI patients have been associated with an increased activation status of the immune system. This augmented activation status is reflected among others by elevated plasma levels of various inflammatory markers such as CRP, TNF- $\alpha$, IL-6 and neopterin ${ }^{3-5,15,16}$. In line with these findings, we hypothesized that an additional depression may further increase systemic levels of inflammatory markers in post-MI patients as compared to non-depressed post-MI patients. Nonetheless, no significant difference in inflammatory status between depressed post-MI patients as compared to non-depressed post-MI patients for any cytokine, cytokine receptor or ISP could be detected although there was a trend for higher neopterin levels $(\mathrm{p}=0.053)$ in depressed post-MI patients. Fifteen percent of all depressed patients had levels $>9.7 \mathrm{mmol} / \mathrm{l}$, compared to $9 \%$ in the non-depressed group. Levels higher than $9.7 \mathrm{mmol} / \mathrm{l}$ have been associated with increased risk of recurrent $\mathrm{Ml}$ or cardiac death in non-Q wave MI patients ${ }^{18}$. If depression in post-MI patients is related to higher neopterin levels, there might be a possible pathophysiological link between neopterin levels and increased cardiac events in depressed post-MI patients.

In the study of van Haelst et al. a strong correlation was found between levels of neopterin determined within 48 hours after admission for MI and levels of neopterin one year post MI. No 
such correlation was found in that study for levels of CRP, indicating that neopterin reflected another inflammatory processes than CRP ${ }^{18}$. In the present study, time elapsed since MI ranged from 3 to 12 months (mean 6.0; s.d 3.3). In post-hoc analyses, time elapsed since MI predicted levels of sTNF-RII and sTNF-RI, but not of sIL-6R, IL-6, neopterin, TNF- $\alpha$ or CRP. The effect of depression however, remained unaltered in these regression models, indicating that time elapsed since MI was not a confounding parameter.

When compared with data reported in somatically healthy individuals ${ }^{4,10-12,22,23}$, in the present study mean levels of sIL-6R, TNF- $\alpha$, sTNF-RII and CR.P were considerably elevated in both depressed and non-depressed post-MI patients despite the fact that all patients were prescribed at least three types of cardiovascular treatment regimens. Because of the relation between elevated inflammatory cytokine levels and detrimental effects on cardiac functioning, interest in the various effects of cardiovascular treatments on inflammatory parameters is increasing. Statins have been shown to reduce parameters of inflammation independent of their cholesterol level ${ }^{24}$. Mechanisms by which statins reduce inflammation are not fully understood, but it has been reported that some decrease secretion of CRP, IL-1, IL-6, neopterin and TNF- $\alpha{ }^{25.26}$. A beta-blocker was shown to lower levels of TNF- $\alpha$ in patients with dilated cardiomyopathy in one study ${ }^{27}$ and in patients with chronic heart failure, ACE inhibitor treatment was associated with a reduction of IL-6 levels and an increase in sIL-6R levels ${ }^{28}$. Mohler et al, have shown that a calcium antagonist lowered plasma IL-6 levels in patients with chronic heart failure ${ }^{29}$. No anti-inflammatory effect of aspirin $325 \mathrm{mg} /$ day given for a period of 8 weeks was found in healthy subjects ${ }^{30}$, but a reduction was observed in patients with chronic stable angina ${ }^{31}$. It is therefore interesting to note that data from the present study show that in spite of treatment diring a mean period of 6 months after MI with at least three prescriptions of cardiac medications that may lower inflammatory status, several inflammatory markers were still elevated when compared with values reported in somatically healthy individuals. Ongoing inflammation in post-MI patients implicates that more research is necessary to assess the extent of immunoregulatory effects of cardiovascular treatment regimens.

In spite of mounting data on the relation between depression and inflammation, until now it remains unclear whether depression promotes an inflammatory response or whether inflammation induces depression. Several studies have shown that administration of cytokines can induce depression in humans ${ }^{32-35}$. Increased inflammation related to $\mathrm{Ml}$ might then be a risk factor for development of depression in the post-MI period. Indeed, prevalence of depression after MI is $13-20 \%{ }^{36.37}$, raising to $20-30 \%$ one year post-MI ${ }^{38,39}$. Increased inflammation might be the consequence of indirect mechanisms such as induced by health behavior. Higher BMI, smoking status and hyperlipidaemia, 
which are also strongly associated with atherosclerosis, have been shown to increase inflammatory parameters ${ }^{10-12}$. In the present study the significant regression model with neopterin as dependent variable showed a significantly predictive effect of smoking. Besides health behavior, stressful psychosocial factors have been shown to induce inflammation ${ }^{40-42}$. Appels et al. demonstrated an association between mental state of coronary patients and inflammation with significantly higher levels of IL-1 $\beta$ and TNF- $\alpha$ in exhausted patients with stable angina pectoris as compared to nonexhausted patients with stable angina pectoris ${ }^{43}$. Recently, in a group of 35 depressed patients undergoing a coronary angiogram for a suspected acute MI or episode of high-risk unstable angina, significantly increased levels of soluble intercellular adhesion molecule-1 were found as compared to 446 non-depressed patients undergoing a coronary angiogram ${ }^{44}$. No significant difference between the groups was found for levels of IL-6 $(1.24, \mathrm{SD}=0.39$ and $1.20, \mathrm{SD}=0.52 \mathrm{pg} / \mathrm{mL}$ in depressed and non-depressed patients respectively). Serum CRP levels were 1.33 (SD=0.77) and $1.23(\mathrm{SD}=0.73) \mathrm{mg} / \mathrm{L}$ respectively. Although the difference was not significant when comparing depressed versus non-depressed, the difference became significant when only depressed patients not taking statins were included in the analysis ${ }^{44}$. In the present study effect of depressed state on levels of inflammatory markers of post-MI patients was assessed. In both cohorts of the present study, prescription of a statin was present in more than $82 \%$ of patients. It can therefore not be excluded that due to statin therapy, the difference in levels of inflammatory markers between the two groups was not detectable anymore.

\section{Conclusion}

Based on earlier observations that both MI and depression are associated with inflammation, we hypothesized that depression in post-MI patients is associated with increased inflammatory status as compared to non-depressed post-MI patients. If so, increased inflammatory parameters = more specifically increased CAD-related inflammatory markers - in depressed posi-MI patients might contribute to increased cardiac morbidity and mortality observed in depressed post-MI patients. Data from the present study showed no additional inflammation in the depressed post-MI group as compared to the non-depressed post-MI group. It might therefore be concluded that immune activation in this cohort was not the most likely candidate in the pathophysiological relationship between depression and MI. Larger cohorts with more information about patient characteristics such as accurate registration of medications (and dosages), co-morbidity, and a more accurate quantification of the extension of atherogenic disease, are necessary in order to know more about the relative contribution of different factors (such as depressive state) to inflammatory status in MI 
patients. Results from research on inflammatory status in MI patients, will contribute to therapeutic strategies which aim at reducing symptoms of depression on the one hand and risk of cardiac events on the other.

\section{Acknowiedgment}

This study was supported by grant no. 2002B207 of the "Netherlands. Heart Foundation".

\section{References}

1. Penninx BW, Beekman AT, Honig A, Deeg DJ, Schoevers RA, van Eijk JT, van Tilburg W. Depression and cardiac mortality: results from a community-based longitudinal study. Arch Gen Psychiatry, 2001;58:221-7.

2. Bush DE, Ziegelstein RC, Tayback M, Richter D, Stevens S, Zahalsky H, Fauerbach JA. Even minimal symptoms of depression increase mortality risk after acute myocardial infarction. $\mathrm{Am} \mathrm{J}$ Cardiol. 2001:88:337-41.

3. Van Der Ven A, Van Diest R, Hamulyak K, Maes M, Bruggeman C, Appels A. Herpes viruses, cytokines, and altered hemostasis in vital exhaustion. Psychosom Med. 2003;65:194-200.

4. Maes M, Bosmans E, De Jongh R, Kenis G, Vandoolaeghe E, Neels H. Increased serum IL-6 and ILI receptor antagonist concentrations in major depression and treatment resistant depression. Cytokine, 1997;9:853-8.

5. Zorrilla EP, Luborsky L, McKay JR, Rosenthal R, Houldin A, Tax A, McCorkle R, Seligman DA, Schmidt K. The relationship of depression and stressors to immunological assays: a meta-analytic review. Brain Behav Immun. 2001:15:199-226.

6. Pasic J, Levy WC. Sullivan MD. Cytokines in depression and heart failure. Psychosom Med. $2003: 65: 181-93$.

7. Owen BM, Eccleston D, Ferrier IN, Young AH. Raised levels of plasma interleukin-lbeta in major and postviral depression. Acta Psychiatr Scand. 2001;103:226-8.

8. Tuglu C, Kara SH, Caliyurt O, Vardar E, Abay E. Increased serum tumor necrosis factor-alpha levels and treatment response in major depressive disorder. Psychopharmacology (Berl). 2003;170:429-33.

9. Penninx BW, Kritchevsky SB, Yaffe K, Newman AB, Simonsick. EM, Rubin S, Ferrucci L, Harris T, Pahor M. Inflammatory markers and depressed mood in older persons: results from the Health, Aging and Body Composition study. Biol Psychiatry. 2003;54:566-72.

10. Miller GE, Stetler CA, Carney RM, Freedland KE, Banks WA. Clinical depression and inflammatory risk markers for coronary heart disease. Am J Cardiol. 2002;90:1279-83.

11. Danner M, Kasl SV, Abramson JL, Vaccarino V. Association between depression and elevated Creactive protein. Psychosom Med. 2003;65:347-56.

12. Kop WJ, Gottdiener JS, Tangen CM, Fried LP, McBurnie MA, Walston J, Newman A, Hirsch C, Tracy RP. Inflammation and coagulation factors in persons $>65$ years of age with symptoms of depression but without evidence of myocardial ischemia. Am J Cardiol. 2002;89:419-24.

13. Maes M, Scharpe S, Van Grootel L, Uyttenbroeke W, Cooreman W, Cosyns P, Suy E. Higher alfa1antitrypsin, haptoglobin, ceruloplasmin and lower retinol binding protein plasma levels during depression: further evidence for the existence of an inflammatory response during that illness. Journal of Affective Disorders. 1992;24:183-192.

14. Ross R. Atherosclerosis-an inflammatory disease. N Engl J Med. 1999:340:115-26.

15. Ridker PM, Rifai N, Pfeffer M, Sacks F, Lepage S, Braunwald E. Elevation of tumor necrosis factoralpha and increased risk of recurrent coronary events after myocardial infarction. Circulation. 2000;101:2149-53. 
36. Anzai T, Yoshikawa T, Shiraki H, Asakura Y, Akaishi M, Mitamura H, Ogawa S. C-reactive protein as a predictor of infarct expansion and cardiac rupture after a first Q-wave acute myocardial infarction. Circulation. 1997:96:778-84.

17. Ridker PM, Rifai N, Stampfer MJ, Hennekens CH. Plasma concentration of interleukin-6 and the risk of future myocardial infarction among apparently healthy men. Circulation. 2000;101:1767-72.

18. van Haelst PL, Liem A, van Boven AJ, Veeger NJ, van Veldhuisen DJ, Cohen Tervaert JW, Gans RO, Zijlstra F. Usefulness of elevated neopterin and $\mathrm{C}$-reactive protein levels in predicting cardiovascular events in patients with non-Q-wave myocardial infarction. Am $J$ Cardiol. 2003:92:1201-3.

19. van den Brink RHS, van Melle J, Honig A, Schene AH, Crijns HJGM, Lambert FPG, Ormel 3. Treatment of depression after myocardial infarction and the effects on cardiac prognosis and quality of life: Rationale and outline of the Myocardial INfarction and Depression - Intervention Trial (MIND-IT). Am Heart J. 2002; 144:219-225.

20. Dati F, Schumann G, Thomas L, Aguzzi F, Baudner S, Bienvenu J, Blaabjerg O, Blirup-Jensen S, Carlstrom A, Petersen PH, Johnson AM, Milford-Ward A, Ritchie RF, Svendsen PJ, Whicher J. Consensus of a group of professional societies and diagnostic companies on guidelines for interim reference ranges for 14 proteins in serum based on the standardization against the IFCC/BCR/CAP Reference Material (CRM 470). International Federation of Clinical Chemistry. Community Bureau of Reference of the Commission of the European Communities. College of American Pathologists. Eur J Clin Chem Clin Biochem. 1996;34:517-20.

21. Hair JF, ed. Multivariate data analysis. Sth ed. Upper Saddle River, New Yersey: Prentice-Hall, Inc. A Simon\& Schuster Company; 1998.

22. Maes M, Meltzer HY, Bosmans E, Bergmans R, Vandoolaeghe E, Ranjan R, Desneyder R. Increased plasma concentrations of interleukin-6, soluble interleukin-6 receptor, soluble interleukin-2 and transferrin receptor in major depression. Journal of Affective Disorders, 1995;34:301-309.

23. Mikova O, Yakimova R, Bosmans E, Kenis G, Maes M. Increased serum tumor necrosis factor alpha concentrations in major depression and multiple sclerosis. Eur Neuropsychopharmacol. 2001:11:203-8.

24. Ridker PM. Rifai N, Clearfield M, Downs JR, Weis SE, Miles JS, Gotto AM, Jí. Measurement of Creactive protein for the targeting of statin therapy in the primary prevention of acute coronary events. N Engl J Med. 2001;344:1959-65.

25. Rosenson RS, Tangney CC, Casey LC. Inhibition of proinflammatory cytokine production by pravastatin. Lancet. 1999;353:983-4.

26. Neurauter G, Wirleitner B, Laich A, Schennach H, Weiss G, Fuchs D. Atorvastatin suppresses interferon-gamma -indiced neopterin formation and tryptophan degradation in human peripheral blood mononuclear cells and in monocytic cell lines. Clin Exp Immonol, 2003;131:264-7.

27. Ohtsuka T, Hamada M, Hiasa G, Sasaki O, Suzuki M, Hara Y, Shigematsu Y, Hiwada K. Effect of beta-biockers on circulating levels of inflammatory and anti-inflammatory cytokines in patients with dilated cardiomyopathy. $J \mathrm{Am}$ Coll Cardiol. 2001;37:412-7.

28. Gullestad L, Aukrust P, Ueland T, Espevik T, Yee G, Vagelos R, Froland SS, Fowler M. Eflect of high-versus low-dose angiotensin converting enzyme inhibition on cytokine leveis in chronic heart failure. J Am Coll Cardiol. 1999:34:2061-7.

29. MohJer ER, 3rd, Sorensen LC, Ghali JK, Schocken DD, Willis PW, Bowers JA, Cropp AB, Pressler ML. Role of cytokines in the mechanism of action of amlodipine: the PRAISE Heart Failure Trial. Prospective Randomized Amlodipine Survival Evaluation. J Am Coll Cardiol. 1997;30:35-41 .

30. Azar RR, Klayme S, Germanos M, Kassab R, Tawm S, Aboujaoude S, Naman R. Effects of aspirin (325 mg/day) on serum high-sensitivity C-reactive protein, cytokines, and adhesion molecules in healthy volunteers. Am .J Cardiol. 2003;92:236-9.

31. Ikonomidis I, Andreotti F, Economou E, Stefanadis C, Toutouzas P, Nihoyannopoulos P. Increased proinflammatory cytokines in patients with chronic stable angina and their reduction by aspirin. Circulation. 1999;100;793-8. 
32. Spriggs DR, Sherman ML, Michie H, Arthur KA, Imamura K, Wilmore D, Frei E, 3rd, Kufe DW. Recombinant human tumor necrosis factor administered as a 24-hour intravenous infusion. A phase I and pharmacologic study. J Natl Cancer Inst. 1988;80:1039-44.

33. Miyaoka H, Otsubo $\mathrm{T}$, Kamijima K, Ishii M, Onuki M, Mitamura K. Depression from interferon therapy in patients with hepatitis C. Am J Psychiatry. 1999;156:1120.

34. Walther EU, Hohlfeld R. Multiple sclerosis: side effects of interferon beta therapy and their management. Neurology. 1999;53:1622-7.

35. Gleason OC, Yates WR. Five cases of interferon-alpha-induced depression treated with antidepressant therapy. Psychosomatics. 1999;40:510-2.

36. Frasure-Smith N, Lesperance F, Talajic M. Depression following myocardial infarction: impact on 6months survival. JAMA. 1993:270:1819-1825.

37. Ladwig KH, Roll G, Breithardt G, Budde T, Borggrefe M. Post infarct depression and incomplete recovery 6 months after acute myocardial infarction. The Lancet. 1994:343:20-23.

38. Honig A, Lousberg R, Wojchiechowski F, Cheriex EC, Wellens H, Van Praag HM. Depression following a first myocardial infarction; similarities with and difference from 'ordinary' depression (Depressie na een eerste hartinfarct: overeenkomsten en verschillen met een gewone depressie). Ned Tijdschr Geneeskunde. 1997;141:196-199.

39. Strik JJ, Lousberg R, Cheriex EC, Honig A. One year cumulative incidence of depresssion following myocardial infarction and impact on cardiac outcome. J Psychosom Res. 2003; in press.

40. Maes M, Song C, Lin A, Gabriels L, De Jongh R, Van Gastel A, Kenis G, Bosmans E, De Meester I, Benoyt I, Neels H, Demedts P, Janca A, Scharpe S, Smith RS. The effects of psychological stress on humans: increased production of proinflammatory cytokines and a Th-1-like response in stressinduced anxiety. Cytokine. 1998;10:313-318.

41. Ackerman KD, Martino M, Heyman R, Moyna NM, Rabin BS. Stressor-induced alteration of cytokine production in multiple sclerosis natients and controls. Pswchosom Med 1998:60:484-91

42. Marshall GD, Jr., Agarwal SK, Lloyd C, Cohen L, Henninger EM, Morris GJ. Cytokine dysregulation associated with exam stress in healthy medical students. Brain Behav Immun. 1998;12:297-307.

43. Appels A, Bar FW, Bar J, Bruggeman C, de Baets M. Inflammation, depressive symptomtology, and coronary artery disease. Psychosom Med. 2000:62:601-5.

44. Lesperance F, Frasure-Smith $\mathrm{N}$, Theroux $\mathrm{P}$, Irwin M. The association between major depression and levels of soluble intercellular adhesion molecule $\mathrm{I}$, interleukin-6, and C-reactive protein in patients with recent acute coronary syndromes. Am J Psychiatry. 2004;161:271-7. 
Chapter 7

Epilogue 


\section{Background}

The World Health Organisation (WHO) has predicted that in 2020 the highest ranking of morbidity will be myocardial infaretion (MI) and in the second place depression '. Patients with a MI have an increased risk to develop depression: the cumulative incidence rate of depression in the general population has been shown to be $5-10 \%$, while the 1-year cumulative incidence of major and minor depression in post-MI patients has been found to be $20-30 \%{ }^{2,3}$.

Depression is not only accompanied by a decrease in quality of life in a group of patients that suffer already the consequences of $\mathrm{MI}$, but depression has also been identified as a significant risk factor for recurrent cardiac events in patients with established cardiovascular disease. In patients with newly diagnosed coronary artery disease (CAD), major depression has been shown to double the risk of an adverse cardiovascular event within 12 months ${ }^{4}$. Odds ratio's for increased cardiac mortality of post-MI depression range from 4.9 in older studies ${ }^{5.6}$ to $2.3-3.0^{7-10}$ in more recent ones. This increased risk is independent of other post-MI risk factors such as left ventricular dysfunction, complex arrhythmias, and history of prior MI.

Both cross-sectional and prospective analyses, have demonstrated that depression is not only an important cardiovascular risk factor for cardiac patients, but also for medically healthy individuals ${ }^{7}$. It is important to note that the increased risk was independent of traditional cardiovascular risk factors such as hypertension, high cholesterol, smoking, age, co-morbidity and increased body mass index.

Besides depression and the more traditional risk factors for cardiovascular disease (such as diabetes mellitus, smoking, diet, hypertension, dyslipidemia and a positive family history for CAD) type-D personality ${ }^{11}$, hostility ${ }^{12,13}$, social isolation ${ }^{14,15}$, low education ${ }^{16}$, vital exhaustion ${ }^{17}$ and anxiety 7,18.19 have been identified as predictors of cardiac death. Social risk factors (living alone, low education), psychological factors (personality characteristics, coping with stress) and neurobiological factors (genetic constitution, diet or lifestyle induced metabolic changes) interact with each other and influence each other ${ }^{19,20}$. Research in the neurobiological field has contributed in understanding how psychological phenomena translate into measurable neurobiological alterations.

Specific neurobiological abnormalities observed in depressed patients have been proposed as mechanisms that may explain the relation between depression and cardiovascular illness: 
- sympathoadrenal dysregulation,

- decreased variability in heart rate,

- dysfunctional blood platelets,

- dysfunctional endothelial function

- dysfunctional fibrinolytic system

- serotonergic dysfunction,

- immune system dysfunction and

- decreased omega-3 polyunsaturated fatty acids

It was the object of the present thesis, to contribute in the unravelling of possible neurobiological mechanisms linking MI and depression. In addition, possible mechanisms linking post-MI depression and increased cardiac morbidity and mortality were also discussed, although they were not a direct object of investigation in the present thesis (see Figure 1). In the present thesis, some aspects of four of the above mentioned neurobiological aspects were addressed, i.e. dysfunctional blood platelets, serotonergic dysfunction, immune system dysfunction and decreased omega- 3 polyunsaturated fatty acids (n-3 PUFAs). Sympathoadrenal dysregulation, decreased variability in heart rate, dysfunctional endothelial function and dysfunctional fibrinolytic system will be addressed as part of the MIND-IT study in the nearby future.

Regarding the present thesis, all neurobiological markers were obtained from blood sample analyses from patients included in the Myocardial INfarction and Depression - Intervention Trial (MINDIT). A separate study was included in this thesis regarding brain imaging data from patients who participated in the brain SPECT study. Results and interpretation of the data of the present thesis, consequences of the findings and ideas for future research will be discussed below. 
Figure 1. Candidate neurobiological factors possibly involved in pathophysiologi.

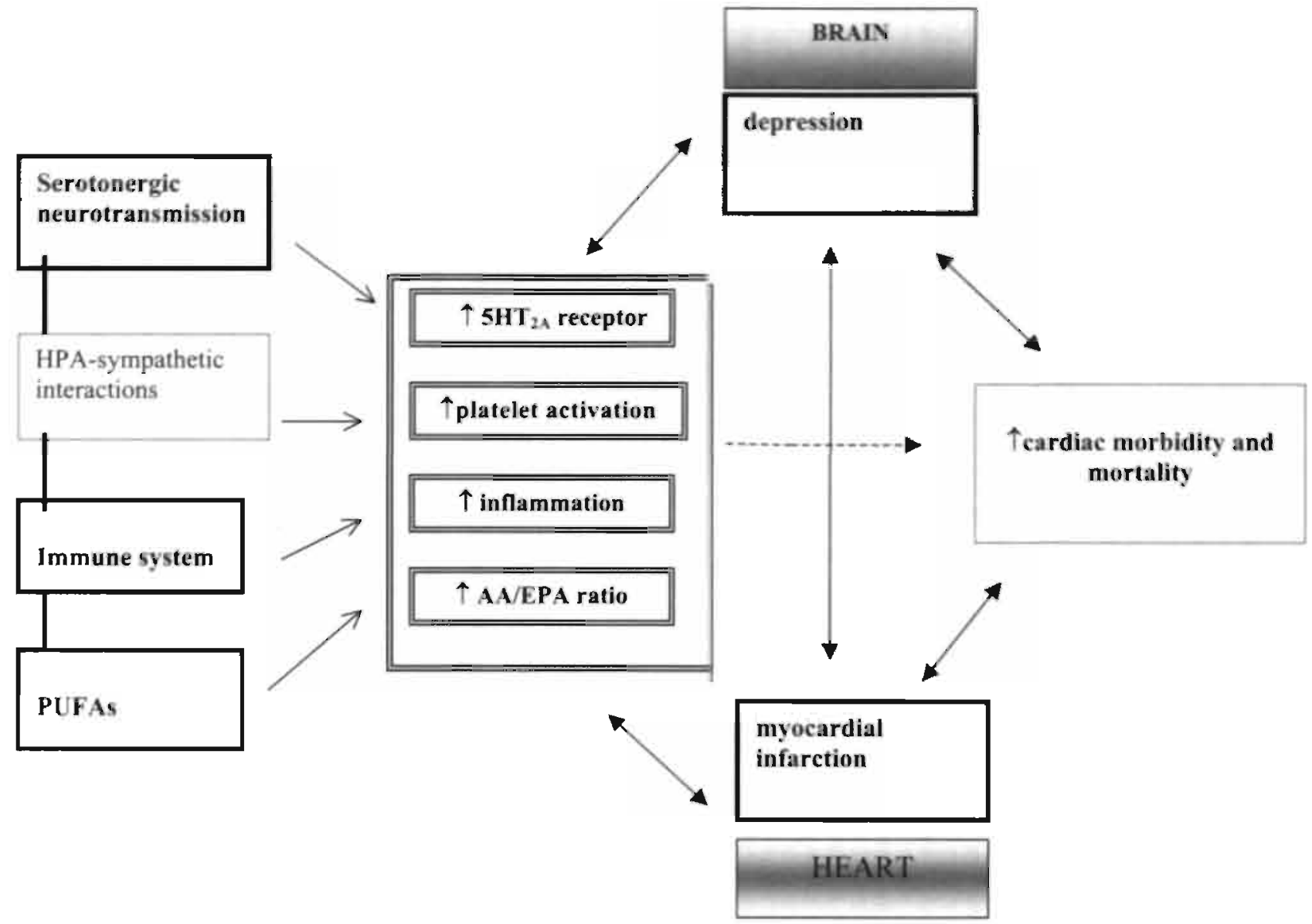




\section{General discussion}

Three chapters of the present thesis deal with studies that analysed blood parameters from both depressed and non-depressed post-MI patients, and one chapter is devoted to brain imaging data. In this section a concise review about a priori hypotheses, the results and the proposed interpretation of data will be given. Finally, an attempt was made to integrate findings with respect to their possible role in the relation between depression and MI, resulting in a final model as presented in figure 2.

First, regarding PUFA status, in the present thesis it was hypothesized that depression post-MI would be associated with a relative deficit of long chain omega 3 PUFAs (n-3 LCPUFA) as measured by higher arachidonic acid (n-6 LCPUFA) / eicosapentanoic acid (n-3 LCPUFA) ratio's (AA/EPA ratio) as compared to non-depressed post-MI patients. Background for this assumption is that lower n-3 LCPUFAs have increasingly been associated with psychiatric disorders, among which schizophrenia, bipolar disorder, and specifically depressive disorder ${ }^{21,22}$. At the same time, lower n-3 PUFAs have been associated with increased prevalence of CAD ${ }^{23,24}$.

In the present thesis higher AA/EPA ratios were found in depressed post-MI patients as compared to non-depressed post-MI patients. The difference remained significant after adjustment for possible confounding variabies. If depression after MI is associated with higher AA/EPA ratios, it may be hypothesized that PUFA status is one of the possible pathophysiological mechanisms linking depression and $\mathrm{MI}$.

There are several mechanisms by which low n-3 LCPUFAs may influence mood. First, n-6/n-3 PUFA composition in membranes influences membrane fluidity and as a consequence membrane functions. For example, experimentally increased rigidity of membranes (by lowering n-3 LCPUFA content) resulted in decreased accessibility of serotonin to its receptor ${ }^{25}$ and the activity of tryptophan hydroxylase, the rate--limiting enzyme in serotonin synthesis, decreased ${ }^{21,26,27}$. Next, low plasma concentrations of n-3 LCPUFAs predicted cerebrospinal fluid 5-hydroxyindolacetic acid (CSF 5-HIAA), a marker of brain serotonin turnover ${ }^{28}$. Second, a relative decrease of $n-3$ LCPUFA derived eicosanoids in favour of $n \cdot 6$ LCPUFA derived eicosanoids, is associated with increased inflammation, and increased inflammation has been associated with depression ${ }^{29,30}$. Third, n-3 LCPUFA depletion has been associated with activation of the hypothalamic-pituitaryadrenal (HPA-axis) ${ }^{31}$, one of the hallmarks of depression. The mechanism behind this association might be mediated through increased CRF release, caused by increased cytokine levels of IL $-1 \beta$ 32,33 . 
In addition to the possible role of PUFA status linking depression and MI, it may even be hypothesized that PUFAs may play a role in the link between depressed post-MI patients and increased cardiovascular events. PUFAs are precursors of eicosanoids involved in prothrombotic and proatherogenic mechanisms (i.e. prostaglandines, thromboxanes, prostacyclines, leukotrienes). AA-derived eicosanoids are more proaggregatory than n-3 LCPUFA- derived eicosanoids ${ }^{34-36}$. N-3 LCPUFA depletion in depressed post-MI patients can be postulated to increase trombo-embolic events through a shift towards production of more prothrombotic eicosanoids. As mentioned before, a relative decrease of n-3 LCPUFA derived eicosanoids in favour of n-6 LCPUFA derived eicosanoids, is associated with increased inflammation and some inflammatory markers such as TNF- $\alpha^{37}$, CRP $^{38}$, IL-6. ${ }^{39}$ and neopterin ${ }^{40}$ have been associated with increased risk of recurrent coronary events. Next, lower n-3 PUFAs have been associated with increased vulnerability to ventricular fibrillation resulting in sudden cardiac death in the setting of $\mathrm{MI}^{4 !}$.

Thus, by modulating serotonergic neurotransmission on the one hand and thrombotic, arrhythmic and inflammatory mechanisms on the other hand, PUFA status may play a central role in a great variety of processes which, when negatively altered, may induce both depressogenic and cardiac diseases, and in combination, may increase clinical outeome measures iñ depressed post-Ml patients such as increased risk of cardiac morbidity and mortality (see Figure 2).

It is well documented that serotonergic pathways are implicated in the pathophysiology of depression ${ }^{42,43}$. With regard to depression in post-MI patients, it has been postulated that increased serotonin-mediated platelet activation in depression may be one of the mechanisms that underlie the increased vulnerability of depressed post-MI patients to cardiac events ${ }^{44}$. As studies from the present thesis all had a cross-sectional study design, the article on platelet-linked parameters focussed on possible associations of platelet linked parameters and post-MI depression, and the brain SPECT study on central 5-HT $2 \mathrm{~A}$ receptor binding looked at differences in ligand binding between depressed and non-depressed post-MI patients.

It was hypothesized that first, depressed post-MI patients have increased platelet activation as compared to non-depressed post-MI patients; second, that depression in post-MI patients is associated with increased levels of whole blood serotonin and third, regarding the brain imaging study, it was hypothesized that depressed post-MI would have increased central 5- $\mathrm{HT}_{2 \mathrm{~A}}$ receptor binding as compared to non-depressed post-MI patients.

Background for the first hypothesis was that depression has repeatedly been associated with increased platelet activation, not only in somatically healthy depressed patients as compared to 
controls, but also in patients with CAD ${ }^{45,46}$. Regarding serotonin, data from literature on blood serotonin levels are not uniform: decreased, increased and no change in depressed patients have been reported ${ }^{47}$. In MI patients, increased serotonin levels have been associated with increased cardiac events ${ }^{48}$.

Platelets have two serotonergic receptors, platelet 5-HTT and 5- $\mathrm{HT}_{2 \mathrm{~A}}$ receptors, which have been shown to be identical to those in the brain. Platelet activation in platelets is mediated by $5-\mathrm{HT}_{2 \mathrm{~A}}$ receptors, and both number and sensitivity of $5-\mathrm{HT}_{2 \mathrm{~A}}$ receptor have been found to be increased in depression ${ }^{49,50}$. Next, in brain studies, depression has been associated with increased number of 5 $\mathrm{HT}_{2 \mathrm{~A}}$ receptors ${ }^{51-53}$, and $5-\mathrm{HT}_{2 \mathrm{~A}}$ receptors have been associated with motor behavior, sensory functions, cognition, emotion, food intake, sleep, body temperature and hormonal release in the brain ${ }^{54}$. Van Praag introduced a subtype of depression that is anxiety and aggression-driven ${ }^{55}$. Diminution of 5-HT metabolism with compensatory upregulation of 5- $\mathrm{HT}_{\mathrm{AA}}$ and $5-\mathrm{HT}_{2 \mathrm{~A}}$ receptors was proposed ${ }^{56}$. A key feature of depressed post-MI patients is hostility ${ }^{3}$, which may have a similar pathophysiologic background as anxiety/aggression driven depression.

Data from the present thesis, showed increased serotonin levels in depressed post-MI patients, no difference in platelet activation, and increased 5- $\mathrm{HT}_{2 \mathrm{~A}}$ receptor ligand binding in the brain.

Regarding whole blood serotonin levels, the data support the hypothesis that depression in post-MI patients may be associated with increased peripheral serotonin levels. Further research is needed to understand more about the mechanism behind this association, because depression is associated on the other hand with decreased serotonin availability and decreased 5-HTT receptors in the brain 43,57. Regarding absence of increased platelet activation, it is important to note that both $\beta$. thromboglobulin ( $\beta$ TG), platelet factor 4 (PF4) are strongly influenced by clinical factors such as degree of vessel disease, blood pressure and sampling-related factors such as stress, exercise, phlebotomy technique, specimen anticoagulation and sample preparation. A potential confounding effect of these factors might have influenced outcome. For future studies it may be advisable to use other measures of platelet activation which are less influenced by such factors, for instance measuring expression of specific glycoproteins on platelet membranes with flow cytometry techniques. The flaw is however that these techniques are practically less easy to perform ${ }^{58}$. Another factor that may have biased outcome is the attenuating effect on parameters of platelet activation that medications such as aspirin and beta-blockers may have had in both cohorts. A third possibility is that in the population of the present thesis, a bias between depressed and nondepressed was present which was responsible for non-depression-related increased platelet activation in the non-depressed group. Future research in post-MI patients requires reducing as 
much as possible confounding by above mentioned influential factors. For instance, stratification on type and number of prescribed medications and exact quantification of the extension of atherogenic disease is indicated.

Finally, regarding data from the SPECT study looking at 5- $\mathrm{HT}_{2 \mathrm{~A}}$ receptor ligand binding in the brain, findings suggest depression-related increased $5-\mathrm{HT}_{2 \mathrm{~A}}$ receptor binding in post-MI patients. Upregulation or increased sensitivity of the 5- $\mathrm{HT}_{2 \mathrm{~A}}$ receptor may be a result of decreased serotonin availability in the synaptic cleft ${ }^{56,59}$, or a failure to downregulate $5-\mathrm{HT}_{2 \mathrm{~A}}$ receptors, as postulated by Yatham ${ }^{60}$.

Regarding inflammatory status, data from literature have shown that both MI and depression are associated with inflammation ${ }^{61-63}$. It was therefore hypothesized that depressed post-Mi patients would have an additional inflammation on top of MI-related inflammation. Results however showed no increased inflammatory status in depressed post-MI patients as compared to nondepressed post-MI patients.

In a recent study, a significant difference in CRP levels between a group of 35 depressed versus 446 non-depressed patients undergoing a coronary angiogram for a suspected acute MI or episode of high-risk unstable angina, became only apparent when depressed patients not taking statins were included in the analysis ${ }^{64}$. In both cohorts of the present thesis, prescription of a statin was present in more than $82 \%$ of patients. It can therefore not be excluded that due to statin therapy, the difference between the two groups was not detectable anymore. Another confounding effect might be due to the differences in time elapsed since MI. Patients were included not before three months elapsed since MI, and not later than 12 months elapsed since MI. However, when adjustment was done in the regression analyses, time elapsed since MI was not a significant predictor of levels of inflammatory markers.

In spite of mounting data on the relation between depression and inflammation, until now it remains unclear whether depression promotes an inflammatory response or whether inflammation induces depression. Several studies have shown that administration of cytokines can induce depression in humans. It is interesting to note that mean levels of sIL-6R, TNF- $\alpha$, sTNF-RII and CRP were considerably elevated in both depressed and non-depressed post-MI patients when compared with data reported in somatically healthy individuals ${ }^{30,65-69}$. Increased inflammation related to MI might then be a risk factor for development of depression in the post-MI period. Indeed, prevalence of depression after MI is increased to $20-30 \%$ one year post-MI. 
Figure 2. Potential interactions between PUFA status and key neurobiological regulatory systems.

Pathophysiological mechan isms

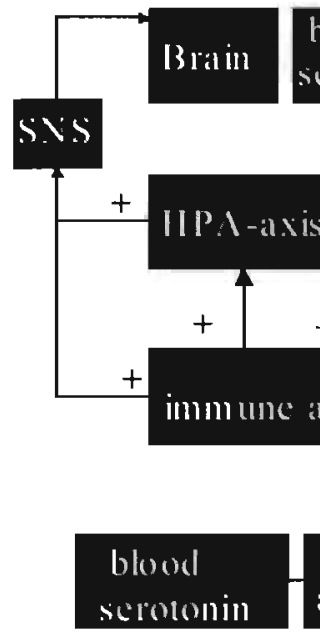

Clinical corre lates

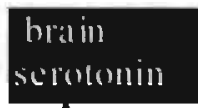

\section{Clinicalcorrelates}


Figure 2 illustrates possible effects of high AA/EPA ratio and other regulatory mechanisms in the body. High AA/EPA ratio and thus a relative deficit of n-3 LCPUFAs leads to a shift towards more activation of the immune system, increased platelet activation, decreased central serotonin turnover and activation of the HPA-axis. In the figure, sites for potential interventions for reducing the risk of developing MI, depression or both can be hypothesized. Data on n-3 LCPUFA supplementation therapy are promising. Preventive supplementation with n-3 LCPUFAs in the acute phase of MI might be considered especially in patients at risk of low n-3 LCPUFA levels, such as patients with a positive history of depression or patients with deficient diet e.g. patients with drug or alcoholic addictions. n-3 LCPUFA supplementation therapy may not only positively influence mood status, but also inflammatory status, brain serotonergic neurotransmission and antithrombotic mechanisms. EPA (or a combination of EPA and DHA) supplementation studies in the early phase of MI may test the hypothesis further.

\section{References}

1. Worid. Hiealth Organisation. 2002.

2. Strik JJ, Lousberg R, Cheriex EC, Honig A. One year cumulative incidence of depresssion following myocardial infarction and impact on cardiac outcome. $J$ Psychosom Res. 2003 ; in press.

3. Honig A, Lousberg $\mathrm{R}$, Wojchiechowski F, Cheriex EC, Wellens H. Van Praag HM. Depression following a first myocardial infarction; similarities with and difference from 'ordinary' depression (Depressie na een eerste hartinfarct: overeenkomsten en verschillen met een gewone depressie). Ned Tijdschr Geneeskunde. 1997;141:196-199.

4. Barefoot JC, Helms MJ, Mark DB, Blumenthal JA, Califf RM, Haney TL, O'Connor CM, Siegler IC, Williams RB. Depression and long-term mortality risk in patients with coronary heart disease. American Journal of Cardiology. 1996;78:613-617.

5. Frasure-Smith N, Lesperance F, Talajic M. Depression following myocardial infarction: impact on 6months survival. JAMA. 1993;270;1819-1825.

6. Ladwig KH, Kieser M, Konig J, Breithardt G, Borggrefe M. Affective disorders and survival after acute myocardial infarction (results from the post-infarction late potential study). Eur Heart $J$. 1991:12:959-964.

7. Penninx BW, Beekman AT, Honig A, Deeg DJ, Schoevers RA, van Eijk JT, van Tilburg W. Depression and cardiac mortality: results from a community-based longitudinal study. Arch Gen Psychiatry. 2001:58:221-7.

8. Denollet J, Vaes J. Brutsaert DL. Inadequate response to treatment in coronary heart disease: adverse effects of type D personality and younger age on 5-year prognosis and quality of life. Circulation. 2000;102:630-5.

9. Welin C. Lappas G. Wilhelmsen L. Independent importance of psychosocial factors for prognosis after myocardial infarction. $J$ Intern Med. 2000;247:629-39.

10. Irvine J, Basinski A, Baker B, Jandciu S, Paquette M, Cairns J, Connolly S, Roberts R, Gent M, Dorian P. Depression and risk of sudden cardiac death after acute myocardial infarction: testing for the confounding effects of fatigue. Psychosom Med. 1999;61:729-37.

11. Denollet J, Sys SU, Stroobant N, et al. Personality as independent predictor of long-term mortality in patients with coronary heart disease. Lancet. 1996:347:417-421. 
12. Barefoot JC, Larsen S, Lieth von der L, Schroll M. Hostlity, incidence of acute myocardial infarction, and mortality in a sample of older Danish men and women. American Journal of Epidemiology. 1995;142:477-484.

13. Whiteman MC, Fowkes FG, Deary IJ. Hostility and the heart. Bmj. 1997;315:379-80.

14. Frasure-Smith N, Lesperance F, Gravel G, Masson A, Juneau M, Talajic M, Bourassa MG. Social support, depression, and mortality during the first year after myocardial infarction. Circulation. 2000;101:1919-24.

15. Penninx BWJH, van Tilburg T, Boeke AJP, Deeg DJH, Kriegsman DMW, van Eijk JTM. Effects of social support and personal coping resources on depressive symptoms: Different for various chronic diseases? Health Psychology *LHM: University Library Maastricht Holding of this journal:SG T. 1992;11.

16. Matthews KA, Kelsey SF, Meilahn EN, Kuller LH, Wing RR. Educational attainment and behavioral and biologic risk factors for coronary heart disease in middle-aged women. Am J Epidemiol. 1989; 129:1132-44.

17. Appels A, Mulder P. Fatigue and heart disease. The association between 'vital exhaustion' and past, present and future coronary heart disease. Journal of Psychosomatic research. 1989:33:727-738.

18. Anda R, Williamson D, Jones D, Macera C, Eaker E, Glassman A, Marks J. Depressed affect, hopelessness, and the risk of ischemic heart disease in a cohort of U.S. adults [see comments]. Epidemiology. 1993;4:285-94.

19. Strik JJ, Denollet J, Lousberg R, Honig A. Comparing symptoms of depression and anxicty as predictors of cardiac events and increased health care consumption after myocardial infarction. $J$ Am Coll Cardiol. 2003;42:1801-7.

20. Maes M, Song C, Lin A, Gabriels L, De Jongh R, Van Gastel A, Kenis G, Bosmans E, De Meester I, Benoyt I, Neels H, Demedts P, Janca A, Scharpe S, Smith RS. The effects of psychological stress on humans: increased production of proinflammatory cytokines and a Th-l-like response in stressinduced anxiety. Cytokine. 1998;10:313-318.

21. Maes M, Christophe A, Delanghe J, Altamura C, Neels H, Meltzer H. Lowered n 3 polyunsaturated fatty acids in serum phospholipids and cholesteryl esters of depressed patients. Psychiatry Res. 1999;85:275-291.

22. Peet M, Murphy B, Shay J, Horrobin D. Depletion of omega-3 fatty acid levels in red blood cell mernbranes of depressive patients. Biol Psychiatry. 1998:43:315-9.

23. Kromhout D. Bosschieter EB, de Lezenne Coulander C. The inverse relation between fish consumption and 20-year mortality from coronary heart disease. $N$ Engl J Med. 1985;312:1205-9.

24. Alberl CM, Hennekens $\mathrm{CH}$, O'Donnel CJ, Ajani UA, Carey VJ, Willet WC, Ruskin JN. Fish consumption and risk of cardiac death. JAMA. 1998;279:23-28.

25. Heron DS, Shinitzky M, Hershkowitz M, Samuel D. Lipid fluidity markedly modulates the binding of serotonin to mouse brain membranes. Proceedings of the National Academy of Sciences of the United States of America. 1980;77:7463-7467.

26. Yehuda S, Rabinovitz S, Mostofsky DI. Essential fatty acids are mediators of brain biochemistry and cognitive functions. J Neurosci Res. 1999;56:565-70.

27. Block ER, Edwards D. Effect of plasma membrane fluidity on serotonin transport by endothelial cells. Am I Physiol. 1987;253:C672-8.

28. Hibbeln JR, Linnoila M, Umhau JC, Rawlings R, George DT, Salem N, Jr. Essential fatty acids predict metabolites of serotonin and dopamine in cerebrospinal fluid among healthy control subjects, and early- and late- onset alcoholics. Biol' Psychiatry. 1998;44:235-42.

29. Connor TJ, Leonard BE. Depression, stress and immunological activation: the role of cytokines in depressive disorders. Life sciences. 1998;62:583-606.

30. Maes M, Meltzer HY, Bosmans E, Bergmans R, Vandoolaeghe E, Ranjan R, Desneyder R. Increased plasma concentrations of interleukin-6, soluble interleukin-6 receptor, soluble interleukin-2 and transferrin receptor in major depression. Journal of Affective Disorders. 1995;34:301-309.

31. Hibbeln J. Long-chain Polyunsaturated fatty Acids in Depression and related Conditions. In: Phospholipid Spectrum Disorder in Psychiatry. Lancashire: Marius Press; 1999:195-209. 
32. Sapolsky R, Rivier C, Yamamoto G, Plotsky P, Vale W. Interleukin-1 stimulates the secretion of hypothalamic corticotropin-releasing factor. Science. 1987;238:522-4.

33. Maes M, Bosmans E, Meltzer HY, Scharpe S, Suy E. Interleukin-I beta: a putative mediator of HPA axis hyperactivity in major depression? Am J Psychiatry. 1993;150:1189-93.

34. Calder PC. Immunoregulatory and anti-inflammatory effects of n-3 polyunsaturated fatty acids. Braz J Med Biol Res. 1998:31:467-90.

35. Vericel E, Calzada C, Chapuy $\mathrm{P}$, Lagarde $\mathrm{M}$. The influence of low intake of $\mathrm{n}-3$ fatty acids on platelets in elderly people. Atherosclerosis. 1999;147:187-92.

36. Malle E, Kostner GM. Effects of fish oils on lipid variables and platelet function indices. Prostaglandins Leukot Essent Fatty Acids. 1993;49:645-663.

37. Ridker PM, Rifai N, Pfeffer M, Sacks F, Lepage S, Braunwald E. Elevation of tumor necrosis factoralpha and increased risk of recurrent coronary events after myocardial infarction. Circulation. 2000:101:2149-53.

38. Anzai T, Yoshikawa T, Shiraki H, Asakura Y, Akaishi M, Mitamura H, Ogawa S. C-reactive protein as a predictor of infarct expansion and cardiac rupture after a first Q-wave acute myocardial infarction. Circulation. 1997:96:778-84.

39. Ridker PM, Rifai N, Stampfer MJ, Hennekens CH. Plasma concentration of interleukin-6 and the risk of future myocardial infaretion among apparently healthy men. Circulation. 2000;101:1767-72.

40. van Haelst PL, Liem A, van Boven AJ, Veeger NJ, van Veldhuisen DJ, Cohen Tervaert JW, Gans RO, Zijlstra F. Usefulness of elevated neopterin and C-reactive protein levels in predicting cardiovascular events in patients with non-Q-wave myocardial infarction. $\mathrm{Am} J$ Cardiol. 2003:92:1201-3.

41. Leaf A, Kang JX, Xiao YF, Billman GE. Clinical prevention of sudden cardiac death by n-3 polyunsaturated fatty acids and mechanism of prevention of arrhythmias by n-3 fish oils. Circulation. 2003; 107:2646-52.

42. Maes M, Meltzer HY. The serotonin hypothesis of major depression. New York: Raven Press; 1995.

43. Owens MJ, Nemeroff CB. Role of serotonin in the pathophysiology of depression: focus on the serotonin transporter. Clin Chem. 1994;40:288-95.

44. Musselman DL, Tomer A, Manatunga AK, Knight BT, Porter MR, Kasey S, Marzec U, Harker LA, Nemeroff CB. Exaggerated platelet reactivity in major depression. Am J Psychiatry. 1996;153:13131317.

45. Laghrissi-Thode F, Wagner WR, Pollock BG, Johnson PC, Finkel MS. Elevated platelet factor 4 and beta-thromboglobulin plasma levels in depressed patients with ischemic heart disease. Biol Psychiatry. 1997:42:290-295.

46. Kuijpers PMJC, Hamulyak K. Strik JMH, Wellens HJJ, Honig A. Beta-thromboglobulin and platelet factor 4 levels in post myocardial infarction patients with major depression. Psychiatry Res. 2002; 109:207-210.

47. Franke L. Schewe HJ, Muller B, Campman V, Kitzrow W, Uebelhack R, Berghofer A, MullerOerlinghausen. B. Serotonergic platelet variables in unmedicated patients suffering from major depression and healthy subjects: relationship between 5HT content and 5HT uptake. Life Sci. 2000;67:301-5.

48. Vikenes K, Farstad M, Nordrehaug JE. Serotonin is associated with coronary artery disease and cardiac events. Circulation. 1999;100:483-489.

49. Pandey GN, Pandey SC, Janicak PG, Marks RC, Davis JM. Platelet serotonin-2 receptor binding sites in depression and suicide. Biol Psychiatry. 1990;28:215-22.

50. Pandey GN, Pandey SC, Dwivedi Y, Sharma RP, Janicak. PG, Davis JM. Platelet serotonin-2A receptors: a potential biological marker for suicidal behavior. Am J Psychiatry. 1995:152:850-5.

51. Yates M, Leake A, Candy JM, Fairbairn AF, McKeith IG, Ferrier IN. $5 \mathrm{HT} 2$ receptor changes in major depression. Biol Psychiatry. 1990:27:489-96.

52. Hrdina PD, Demeter E, Vu TB, Sotonyi P, Palkovits M. 5-HT uptake sites and 5-HT2 receptors in brain of antidepressant-free suicide victims/depressives: increase in 5-HT2 sites in cortex and amygdala. Brain Res. 1993;614:37-44. 
53. Stanley M, Mann JJ. Increased serotonin-2 binding sites in frontal cortex of suicide victims. Lancet. 1983;1:214-6.

54. Barnes NM, Sharp T. A review of central 5-HT receptors and their function. Neuropharmacology. 1999;38:1083-152.

55. van Praag HM. Faulty cortisol/șerotonin interplay. Psychopathological and biological characterisation of a new, hypothetical depression subtype (SeCa depression). Psychiatry-Res. 1996;65:143-57.

56. Van Praag HM. Anxiety/aggression--driven depression. A paradigm of functionalization and verticalization of psychiatric diagnosis. Prog Neuropsychopharmacol Biol Psychiatry. 2001;25:893924.

57. Malison RT, Price LH, Berman R, van Dyck Cil, Pelton GH, Carpenter L, Sanacora G, Owens MJ, Nemeroff CB, Rajeevan N, Baldwin RM, Seibyl JP, Innis RB, Charney DS. Reduced brain serotonin transporter availability in major depression as measured by [123I]-2 beta-carbomethoxy-3 beta-(4iodophenyl)tropane and single photon emission computed tomography. Biof Psychiatry. 1998:44:1090-8.

58. Gurney $\mathrm{D}_{1}$ Lip GY, Blann AD. A reliable plasma marker of platelet activation: does it exist? Am .J Hematol. 2002;70:139-44.

59. Meyer JH, McMain S, Kennedy SH, Korman L, Brown GM, DaSilva JN, Wilson AA, Blak T, Eynan-Harvey R, Goulding VS, Houle $S_{4}$, Links P. Dysfunctional attitudes and 5-HT2 receptors during depression and self- harm. Am J Psychiatry. 2003;160:90-9.

60. Yatham LN, Liddle PF. Shiah IS, Lam RW, Adam MJ, Zis AP, Ruth TJ. Effects of rapid tryptophan depletion on brain 5-HT(2) receptors: a PET study. Br J Psychiatry. 2001:178:448-53.

61. Tuglu C, Kara SH, Caliyurt O, Vardar E, Abay E. Increased serum tumor necrosis factor-alpha levels and treatment response in major depressive disorder. Psychopharmacology (Berl). 2003;170:429-33.

62. Penninx BW, Kritchevsky SB, Yaffe K, Newman AB, Simonsick EM, Rubin S, Femicci L, Harris T, Pahor M. Inflammatory markers and depressed mood in older persons: results from the Health, Aging and Body Composition study. Biol Psychiatry, 2003;54:566-72.

63. Van Der Ven A, Van Diest. R, Hamulyak K, Maes M, Bruggeman C, Appels A. Herpes viruses, cytokines, and altered hemostasis in vital exhaustion. Psychosom Med. 2003;65:194-200.

64. Lesperance F, Frasure-Smith N, Theroux P, irwin M. The association between major depression and levels of soluble intercellular adhesion molecule 1 , interleukin- 6 , and C-reactive protein in patients with recent acute coronary syndromes. Am J Psychiatry. 2004;161:27!-7.

65. Mikova $\mathbf{O}$, Yakimova $\mathrm{R}$, Bosmans $\mathrm{E}$, Kenis $\mathrm{G}$, Maes $\mathrm{M}$. Increased serum tumor necrosis factor alpha concentrations in major depression and multiple sclerosis. Eur Neuropsychopharmacol. 2001:11:203-8.

66. Maes, M, Bosmans E, De Jongh R, Kenis G, Vandoolaeghe E, Neels H. Încreased serum !L- 6 and ILI receptor antagonist concentrations in major depression and treatment resistant depression. Cytokine. 1997;9:853-8.

67. Miller GE, Stetler CA, Carney RM, Freedland KE, Banks WA. Clinical depression and inflammatory risk markers for coronary heart disease. Am J Cardiol. 2002;90:1279-83.

68. Kop WJ, Gottdiener JS, Tangen CM, Fried LP, McBurnie MA, Walston J, Newman A, Hirsch C, Tracy RP. Inflammation and coagulation factors in persons $>65$ years of age with symptoms of depression but without evidence of myocardial ischemia. Am. J Cardiof. 2002;89:41 9-24.

69. Danner M, Kasl SV, Abramson JL, Vaccarino V. Association between depression and elevated C. reactive protein. Psychosom Med. 2003;65:347-56. 



\section{Summary}

There is mounting evidence from literature that patients with a myocardial infarction (MI) have an increased risk to develop depression and depression has been identified as a significant independent risk factor for recurrent cardiac events in patients with established cardiovascular disease. Both cross-sectional and prospective analyses, have demonstrated that depression is not only an important cardiovascular risk factor for cardiac patients, but also for medically healthy individuals. Specific neurobiological abnormalities observed in depressed patients (such as sympathoadrenal dysregulation, decreased variability in heart rate, dysfunctional blood platelets, dysfunctional endothelial function, dysfunctional fibrinolytic system, serotonergic dysfunction, immune system dysfunction and decreased omega-3 polyunsaturated fatty acids) have been proposed as mechanisms that may play a role in the relation between depression and cardiovascular illness.

It is the object of the present thesis, to contribute in the unravelling of possible neurobiological mechanisms linking heart and mind, more specifically MI and depression. In addition, possible mechanisms linking post-MI depression and increased cardiac morbidity and mortality are also discussed, although they were not a direct object of investigation.

The present thesis addresses four topics that are possibly involved in the pathophysiology of depression and MI: omega-3 polyunsaturated fatty acids (Part 1), platelets and serotonin (Part 2), brain 5- $\mathrm{HT}_{2 \mathrm{~A}}$ receptor status (Part 3) and the immune system (Part 4).

The dissertation is therefore divided in four parts (chapter I to 6). It is preceded by an introduction (Prologue) and closed by a general discussion (Epilogue).

The prologue provides a background regarding data from literature about the postulated pathophysiological mechanisms linking depression and $\mathrm{MI}$ and gives a short introduction in the four main topics investigated in this thesis.

Chapter 1 is a review article regarding long chain omega- 3 polyunsaturated fatty acid (n-3 LCPUFA) status as possible link between MI and depression on the one hand and depression post$\mathrm{Ml}$ and increased risk of cardiac events on the other hand. Literature on PUFA status in depressive disorder and in patients with cardiovascular disease is reviewed. The influence of n-3 PUFAs on the structure and function of membrane domains, their involvement in eicosanoid synthesis, inflammatory responses and their influence on intra-cellular signalling pathways and gene expression is explored. Limited data concerning effects of antidepressant treatment on PUFA status 
have been published. Regarding n-3 PUFA supplementation studies, reduction of sudden cardiac death in MI patients and symptom reduction in bipolar disorder has been reported.

In chapter 2 long chain omega-3 PUFA ( $\mathrm{n}-3$ LCPUFA) status as measured by arachidonic acid (n-6 LCPUFA) / eicosapentanoic acid (n-3 LCPUFA) ratio (AA/EPA ratio) is investigated in depressed post-MI patients as compared to non-depressed post-MI patients. Lower n-3 LCPUFAs have been associated with depressive disorder and at the same time, lower n-3 PUFAs have been associated with increased prevalence of coronary artery disease. Higher AA/EPA ratios are found in depressed post-MI patients as compared to non-depressed post-MI patients. If depression after MI is associated with higher AA/EPA ratios, it may be hypothesized that PUFA status is one of the possible pathophysiological mechanisms linking depression and MI. Mechanisms by which low n-3 LCPUFAs may influence mood are described. Because a relative n-3 LCPUFA depletion is associated with a shift towards increased production of prothrombotic and proatherogenic eicosanoids and increased inflammatory markers, it is also hypothesized that PUFAs may play a role in the link between depressed post-MI patients and increased cardiovascular events.

Chapter 3 is a review article on platelet activation and platelet aggregation measures in depressed patients with or without concomitant cardiovascular disease. Data on the influence of antidepressants on parameters of platelet activation are summarized. There is an indication of enhanced platelet activation and aggregation in depressed patients. Patients with a depressive disorder show signs of a hyperactive platelet 5- $\mathrm{HT}_{2 \mathrm{~A}}$ receptor signal transduction system as measured by increased platelet calcium mobilization after stimulation of platelets with serotonin. Depression appears to be associated with an increased susceptibility for serotonin-mediated platelet activation. Increased platelet activation based on a hyperreactive $5-\mathrm{HT}_{2 \mathrm{~A}}$ receptor signalling system, may be influenced by antidepressant medication which antagonizes platelet $5-\mathrm{HT}_{2 \mathrm{~A}}$ receptors.

In chapter 4 whole blood serotonin levels and platelet activation are subject of investigation in depressed versus non-depressed post-MI patients. It has been postulated that increased serotoninmediated platelet activation in depression may be one of the mechanisms that underlie the increased vulnerability of depressed post-MI patients to cardiac events and increased levels of blood serotonin have been associated with increased thrombo-embolic events in MI patients. Whole blood serotonin levels are significantly higher in depressed post-MI patients as compared to non-depressed post-MI patients, but plasma levels of $\beta$ TG, PF4 and $\mathrm{sCD} 40 \mathrm{~L}$ are not statistically different between the 
groups. Regarding whole blood serotonin levels, the data support the hypothesis that depression in post-MI patients may be associated with increased peripheral serotonin levels but regarding platelet activation, data do not support the hypothesis that increased platelet activation may be present in depressed post-MI patients as compared to non-depressed post-MI patients. Treatment with mirtazapine results in a non-significant decrease in $\beta$ TG and PF4 and an increase in whole blood serotonin levels.

In chapter 5 results from a brain imaging study on central $5 \cdot \mathrm{HT}_{2 \mathrm{~A}}$ receptor binding in depressed and non-depressed post-MI patients is given. It is well documented that serotonergic pathways are implicated in the pathophysiology of depression. In platelets both number and sensitivity of 5- $\mathrm{HT}_{2 \mathrm{~A}}$ receptors have been found to be increased in depression and in the brain, depression has been associated in some studies with increased number of $5-\mathrm{HT}_{2 \mathrm{~A}}$ receptors. Data show increased frontal $5-\mathrm{HT}_{2 \mathrm{~A}}$ receptor ligand binding in the brain of depressed post-Ml patients as compared to nondepressed post-MI patients. Upregulation or increased sensitivity of the $5-\mathrm{HT}_{2 \wedge}$ receptor may be a result of decreased serotonin availability in the synaptic cleft, or a failure to downregulate $5-\mathrm{HT}_{2 \Lambda}$ receptors.

In chapter 6 inflammatory status as assessed by measurement of cytokines IL- 6 and TNF- $\alpha$; the soluble cytokine receptors sIL-6R, sTNF-RI and sTNF-RII; neopterin; and the inflammationsensitive plasma proteins (ISPs) CRP and haptoglobin is reported in a group of 57 patients with a diagnosis of depression posi-MI and in a control group of 46 non-depressed post-MI. Data from literature have shown that both $\mathrm{MI}$ and depression are associated with inflammation. Results show no increased inflammatory status in depressed post-MI patients as compared to non-depressed postMI patients. Possible confounding factors such as high percentage of patients receiving statins are discussed. The conclusion is that there is no indication of increased inflammation in depressed postMI patients as compared to non-depressed post-MI patients.

In the epilogue the main conclusions of the thesis are summarized and an attempt is made to integrate findings with respect to their possible role in the relation between depression and MI, resulting in a final model as presented in figure 2. 



\section{Samenvatting}

Er zijn steeds meer aanwijzingen uit de literatuur dat patiënten met een myocard infarct (MI) een verhoogd risico hebben om een depressieve stoornis te ontwikkelen. Daarbij blijkt het hebben van een depressieve stoornis een significante onafhankelijke risicofactor te zijn voor het krijgen van een recidief cardiovasculaire gebeurtenis bij patiěnten met reeds aanwezig hart- en vaatlijden. Zowel cross-sectionele als prospectieve studies, hebben aangetoond dat depressie niet alleen een belangrijke cardiovasculaire risicofactor voor cardiaal belaste patiēnten maar ook voor gezonde individuen is. Specifieke neurobiologische afwijkingen die bij depressiviteit zijn geobserveerd (zoals sympatisch-adrenerge dysregulering, afgenomen variabiliteit in het hartritme, dysfunctionele bloedplaatjes, afwijkende endotheelfunctie, afwijkingen in het fibrinolytisch systeem, serotonerge dysfunctie, afwijkingen in het immuunsysteem, en afgenomen omega-3 meervoudig verzadigde vetzuren) zijn voorgesteld als mechanismen die mogelijk een rol spelen in de relatie tussen het voorkomen van depressieve klachten en cardiovasculaire ziektes.

Het is de opzet van dit proefschrift om bij te dragen aan het ontrafelen van mogelijke neurobiologische mechanismen die ten grondslag liggen aan de relatie tussen het hart en de psychische gestelienis (linking heart and mind: titel proefschrift), in het bijzonder tussen Ml en depressie. Daarnaast wortt ook ingegaan op de mogelijke factoren die een rol zouden kunnen spelen in de relatie tussen post-MI depressie en verhoogde cardiovasculaire morbiditeit en mortaliteit. Dit laatste is echter niet direct onderzocht in dit proefschrift. Het proefschrift omvat vier onderwerpen die mogelijk betrokken zijn in de pathofysiologie van depressie en MI: omega-3 meervoudig verzadigde vetzuren (Deel 1), plaatjes en serotonine (Deel 2), 5- $\mathrm{HT}_{2 \mathrm{~A}}$ receptor binding in de hersenen (Deel 3), en het immuun systeem (Deel 4). Het proefschrift is opgesplitst in vier delen (hoofdstuk 1 tot en met 7). Het wordt voorafgegaan door een inleiding (Proloog) en wordt afgesloten met een algemene beschouwing (Epiloog).

De proloog geeft een overzicht van de literatuur ten aanzien van voorgestelde pathofysiologische mechanismen tussen het optreden van depressieve klachten en MI en het geeft een korte inleiding op de vier onderwerpen die in dit proefschrift onderwerp van onderzoek zijn.

Hoofdstuk 1 is een overzichtsartikel over de rol van lange keten omega-3 meervoudig onverzadigde vetzuren (n-3LCPUFA) in de relatie tussen MI en depressie aan de ene kant en in de relatie tussen post-MI depressie en toegenomen risico op cardiovasculaire gebeurtenissen aan de andere kant. Literatuur ten aanzien van PUFA status in depressieve patiěnten en patiënten met hart- en vaatziekten is samengevat. De invloed van n-3PUFA's op structuur en functie van membranen, hun rol bij eicosanoid synthese, inflammatoire reacties en hun invloed op intra-cellulaire signaaltransductie en gen expressie wordt uiteengezet. Weinig is bekend over het effect van antidepressiva op PUFA status. Ten aanzien van PUFA supplementatie studies is 
een afname van cardiale dood in MI patiënten en een reductie in symptomen van bipolaire stoornis gerapporteerd.

Hoofdstuk 2 rapporteert de bevindingen van lange keten omega-3 meervoudig onverzadigde vetzuren (n-3 LCPUFA) in depressieve en niet depressieve post-MI patiënten, uitgedrukt als arachidonzuur/timnodonzuur ratio (AA/EPA ratio). Een vermindering van n-3 LCPUFAs is waargenomen bij depressieve patiënten en tevens is een vermindering van n-3 LCPUFAs in verband gebracht met verhoogde prevalentie van hart- en vaatziekten. Vergeleken met niet-depressieve post-MI patiênten, hebben de depressieve post-MI patiēnten hogere AA/EPA ratio's. Als depressie na MI geassocieerd is met hogere AA/EPA ratio's, dan zou PUFA status één van de pathofysiologische mechanismen kunnen zijn die ten grondslag liggen aan de relatie tussen MI en depressie. De wijze waarop PUFAs stemming kunnen beĭnvloeden wordt beschreven. Omdat een relatieve n-3 LCPUFA depletie geassocieerd is met toename van prothrombotische en proatherogene eicosanolden en een toename van inflammatoire parameters, kan men veronderstellen dat PUFAs tevens een rol spelen in de relatic tussen depressie post-MI en toename van cardiovasculaire gebeurtenissen.

Hoofdstuk 3 is een overzichtsartikel over plaatjesactivatie en plaatjesaggregatie in depressieve patienten met of zonder coronairlijden. Data over het effect van antidepressieve medicatie op plaatjesactivatie wordt uiteengezet. Er zijn aanwijzingen dat plaatjesactivatie is toegenomen in depressieve patiënten. Plaatjes van patiènten met een depressieve stoornis vertonen een hyperactief $5-\mathrm{HT}_{2 \mathrm{~A}}$ signaal transductie systeem, gemeten door toename van het vrijkomen van calcium na stimulatie van plaatjes met serotonine. Depressie lijkt samen te gaan met een toegenomen gevoeligheid voor serotonine-gemedieerde plaatjesactivatie. Toegenomen plaatjesactivatie gebaseerd op een hyperactief $5-\mathrm{HT}_{2 \mathrm{~A}}$ signaal transductie systeem, zou beïnvloed kunnen worden dooז antidepressieve medicatie die de $5-\mathrm{HT}_{2 \mathrm{~A}}$ receptor antagoneert.

In hoofdstuk 4 wonden serotonine bloedspiegels en plaatjesactivatie onderzocht in depressieve en nietdepressieve post-MI patiẹnten. Toegenomen serotonine-gemedieerde plaatjesactivatie in depressieve patiēnten is naar voren gebracht als ẹ vạn de meçhanismen die ten grondslag kunnen liggen aan de toegenomen gevoeligheid van depressieve post-MI patiēnten voor çardiovasculaire gebeurtenissen en verhoogde serotonine bloedspiegels zijn in verband gebracht met toegenomen thrombo-embolische gebeurtenissen in MI patiēnten. In de depressieve post-MI patiễnten bleken de serotonine bloedspiegẹls significant hoger te zijn dan bij de niet-depressieve post-MI patiēnten. Bloedspiegels van $\beta$ TG. PGF4 en sCD40L waren echter niet verschillend tussen beide groepen. De uitkomst ten aanzien van de serotonine spiegels ondersteunt de hypothese dat depressie in post-MI patiěnten geassocieerd is met verhoogde serotonine spiegels, maar ten aanzien van de plaatjeasactivatie is er geen ondersteuning voor de hypothese dat depressie post-MI gepaard gaat met verhoogde plaatjesactivatie. Behandeling met mirtazapine gaf een 
niet-significante daling in bloedspiegels van $\beta$ TG en PF4 en een niet-significante toename in serotonine bloedspiegels.

De data over 5- $\mathrm{HT}_{2 \mathrm{~A}}$ receptor binding in de hersenen in depressieve en niet-depressieve post-MI patiěnten zijn in hoofdstuk 5 beschreven. Literatuurgegevens wijzen op de betrokkenheid van het serotonerge systeem in de pathofysiologie van depressie. Studies hebben laten zien dat depressie samen gaat met zowel een toegenomen aantal als een toegenomen gevoeligheid van $5-\mathrm{HT}_{2 \mathrm{~A}}$ receptoren op plaatjes en in de hersenen hebben sommige studies uitgewezen dat depressie samen gaat met een toename van aantal $5-\mathrm{HT}_{2 \mathrm{~A}}$ receptoren. De gegevens laten een toename zien van $5-\mathrm{HT}_{2 A}$ receptor binding in de frontale hersenkwab in de depressieve post-MI patiēnten vergeleken met de niẹt-depressieve post-MI patiēnten. Opregulering of toegenomen gevoeligheid van de $5-\mathrm{HT}_{2 \wedge}$ receptor zou een resultaat kunnen zijn van verminderde beschikbaarheid van serotonine in de synaptische spleet of door een onvermogen om 5-HT $2 \mathrm{~A}$ receptoren te downreguleren.

In hoofdstuk 6 zijn inflammatoire parameters zoals cytokine IL-6, TNF- $\alpha$, de oplosbare cytokine receptoren sIL-6R, sTNF-RI en sTNF-RII, neopterine, en de acuut fase eiwitten CRP en haptoglobine bepaald in een groep van 57 patiěnten met een depressie na een $\mathrm{MI}$ en in een controle groep van 46 niet-depressieve patiênten na MI. Gegevens uit de literatuur hebben een toegenomen inflammatoire status beschreven bij zowel depressieve als MI patiënten. De resultaten wijzen op de afwezigheid van een toegenomen inflammatoire status bij depressieve post-Mí patiěnten ten opzichte van đe niet-depressieve post-MI patiënten. Het effect. van mogelijke confounders zoals de inname van statines op de resultaten, wordt aan de orde gebracht. De conclusie is dat er geen aanwijzingen zijn van een toegenomen inflammatoire status bij depressieve post-MI patiënten ten opzichte van de niet-depressieve post-MI patienten.

In de epiloog worden de belangrijkste conclusies samengevat en wordt een voorstel gedaan om de verschillende bevindingen te integreren ten aanzien van hun mogelijke betrokkenheid in de relatie tussen depressie en MI. Dit leidt tot een integraal model dat in figuur 2 is weergegeven. 
Da n k w o o d 


\section{Dankwoord}

Op 1 april 2000 stapte ik in een reeds lopende trein. Het protocol van de MIND-IT studie lag klaar en in Maastricht en Amsterdam waren reeds de eerste patiěnten geîncludeerd. Ik kon aan de slag met een buitengewoon interessant project: De Myocardial Infarction and Depression - Intervention Trial (MIND-IT) ten uitvoer brengen in het Academisch Ziekenhuis van Maastricht en het Atrium Medisch Centrum van Heerlen. Alle patiënten die vanaf april 2000 met een hartinfarct opgenomen zouden worden in de ziekenhuizen van Maastricht of Heerlen, zouden door ons worden benaderd om aan het onderzoek deel te nemen. Gedurende een jaar werden de patiënten gescreend voor het ontstaan van stemmingsklachten, en bij optreden van een depressie, werd hun een dubbel-blinde behandeling met een antidepressief middel dan wel placebo aangeboden. Vóór start van de dubbelblinde behandeling en na 8 weken werd bloed afgenomen dat zou worden onderzocht op vetzuur status, immuun status en bloedplaatjes-activatie; de hoofdonderwerpen van dit proefschrift.

Alle noordelijke MIND-IT hoofdonderzoekers en collega's wil ik hartelijk danken. We hebben, ieder vanuit zijn eigen plek, veel geînvesteerd en bijgedragen. Prof. Hans Ormel (MIND-IT hoofdonderzoeker), prof. Aart Schene (MIND-IT hoofdonderzoeker), Rob van den Brink en Rob Bieringa, Joost van Melle, Astrid Kuyper, Amo Moons, Dorien Tulner, dit proefschrift dank ik tevens aan jullie medewerking. Peter de Jonge, ook jij zeer bedankt voor het feit dat je in korte tijd veel voor de MIND-IT studie hebt betekend. Astrid en Aart, ik denk dat jullie nuchtere en onbaatzuchtige inbreng op cruciale momenten van groot belang is geweest: daarvoor mijn waardering.

Mijn promotor, prof. Dr. Jim van Os, en de voorzitter van de leescommissie, prof. Dr. Robert-Jan Brummer wil ik hartelijk danken voor de samenwerking. Robert-Jan, met name bij het artikel over de polyunsaturated fatty acids heb ik dankbaar gebruik mogen maken van je kennis.

Mijn co-promotor, Dr. A. Honig (tevens MIND-IT hoofdonderzoeker). Beste Adriaan, bij de eerste kennismaking moest ik terugdenken aan de product managers en business unit managers van het farmaceutisch bedrijf waar ik net vandaan kwam. Je bent een zeer snelle beslisser, en weet zeer snel wat je wel of niet aanspreekt. Ik wil je graag bedanken voor de goede samenwerking gedurende het volledige promotietraject; het resultaat heb ik voor een groot deel daaraan te danken! 
Toon en Piet Honig, hartelijk dank voor jullie inzet op het laboratorium Medische Microbiologie. Zoveel bloedmonsters zullen jullie niet snel weer onder handen krijgen! Heel veel succes met jullie studie en toekomstplannen.

Ik kijk terug op een zeer prettige samenwerking met prof. Harry Crijns (MIND-IT hoofdonderzoeker), prof. Michael Maes en Richel Lousberg, de specialist inzake de statistische analyses van de data. Ik wil jullie bedanken voor de kritische beoordeling van de manuscripten, die de kwaliteit ten goede kwam.

Sandra, de uitvoering van de MIND-IT in het Zuiden is onafscheidelijk met jou verbonden. De volledige dataverzameling in Maastricht en Heerlen is in samenwerking met jou tot stand gekomen. Het was gezellig op de kamer en ik wil je bedanken voor je geduld en betrokkenheid en de loyaliteit waarmee je zelfs na het afronden van je werkzaamheden voor de MIND. IT nog interviews hebt gedaan. Ik wens je heel veel succes met je nieuwe baan waar je veel plezier in hebt: de opleiding tot klinisch psycholoog.

Hartinfarct patiěnten krijgen onderzoeken waar arts-assistenten psychiatrie niet zo goed mee uit de voeten kunnen. Petra Kuijpers en Jos Habets in Maastricht en Leo Baur in Heerlen, hartelijk dank voor de inzet bij het beoordelen c.q. uitvoeren van electrocardiogrammen en echo-opnames voor de linker ventrikel functie van het hart.

Veel energie, overleg en geduld was nodig voor de SPECT studie. Marinus Van Kroonenburgh en prof. Koen Van Laere, het was een interessante ervaring met jullie vakgebied bezig te zijn. Hartelijk dank voor de hulp ten aanzien van het specialistische voorwerk dat gedaan moest worden voordat de data geanalyseerd konden worden.

Zeer dankbaar ben ik voor de samenwerking met Gert Grauls, Frank Stassen, prof Cathrien Bruggeman van het Laboratorium Medische Microbiologie van het AZM; Carina van Zandvoort, Dave Hellenbrand, Carol Starren, René van Oerle en Karly Hamulyák van het Laboratorium Speciële Stolling van het AZM, Loe Habets van het laboratorium Klinische Chemie van het AZM; Robert Verkerk van de Universiteit van Antwerpen, prof. Joris. Delanghe van de Universiteit van Gent, Annick Wauters van het laboratorium Klinische Chemie in Antwerpen. Frank, mijn oprechte dank voor je inzet op een cruciaal moment! 
Veel waardering heb ik voor Jos, Jacqueline, Tim en Stefan van de IT afdeling. Ondanks de vele vragen die jullie voortdurend krijgen, blijft de drempel laag om bij jullie aan te kloppen. Bedankı voor jullie goede humeur bij ongelukken.

Ook Laurent, Ankie en Marco wil ik bedanken. Laurent, toen niemand de bomen door het financiële MIND-IT bos meer kon overzien, heb jij de klus geklaard. Marco, altijd als ik haast had, kreeg jij het voor elkaar om dat te doorbreken. Zorgvuldigheid is in jouw vak belangrijker dan haast, en dat lukt je uitstekend. Jullie drie zijn een goed team! Bedankt voor alle ondersteuning.

In harde tijden heeft de promovendus slechts één ding nodig om overeind te blijven: een lekker warm kopje koffie. Ron, Wilco en Bert, werkzaam in het Medisch Archief van het Atrium Medisch Centrum: mijn dank is groot voor alle keren dat ik mee mocht doen met een ronde koffie.

Ook Fabiẽnne, Dorothee en Monique van de poli cardiologie in Heerlen ben ik dank verschuldigd voor de hulp bij lastige vragen: echo's regelen, een kamer regelen en gegevens opzoeken. Door jullie hulp is het onderzoek in het Atrium Medisch Centrum vooruit gekomen!

Dan zijn er van die mensen die zeer bekwaam zijn, maar pas op de voorgrond treden als er nood aan de man is: Gunther Kenis, zeer bedankt voor het delen van je kennis en je behulpzaamheid. Veel succes met het afronden van je eigen promotie!

De linker vlẹugel van de derde verdieping van het dr.Tansgebouw was essentieel. Kirsten, Ineke, Aggi, Margo, Maddy, Philomeen, bedankt voor jullie hulp. Kitty, afspraken maken en afzeggen kon altijd, moeilijke vragen stellen ook: bedankt. Miriam Habex, ook jou wil ik bedanken voor je hulp op belangrijke momenten.

Mijn huidige kamergenoten (Susan, Miriam en Susanne) zijn onmisbaar geweest in de eindfase van mijn promotie. Het was leuk om tussendoor van gedachten te wisselen over actuele onderwerpen in de maatschappij, een verjaardag te vieren en de snoepdoos tijdig te legen en weer bij te vullen. Bedankt voor de gezelligheid en het meedenken. Zeer veel succes toegewenst met jullie toekomst en promotie! 
Tot slot, mijn dank aan alle collega's buiten het MIND-IT gebeuren. In het bijzonder Mariel statistieken, databases, filosoferen, discussiëren, musiceren, boeken uitwisselen... dat alles he ${ }_{\mathrm{ft}}$ een ereplaats in mijn hippocampus gekregen. Tessa, bedankt voor het lenen van je keyboard, je weet al hoeveel plezier we ervan hebben gehad. Succes met jullie promotie onderzoek en verd loopbaan! 


\section{Curriculum vitae}

Annique Schins werd geboren op 22 november 1968 te Tegelen. Na het behalen van het Europees Baccalaureaatsdiploma aan de Europese school van Varese (Italië), ging ze in 1986 geneeskunde studeren aan de Universiteit van Amsterdam (UVA), alwaar ze in 1993 haar artsdiploma behaalde. Van 1994, tot 1998 heeft ze als arts-assistent psychiatrie gewerkt in het voormalig algemeen psychiatrisch ziekenhuis De Grote beek (nu GGZ Eindhoven en de Kempen) en op de PAAZ afdeling van het St. Jozefziekenhuis in Kerkrade. Daaropvolgend heeft ze van 1998 tot 2000 als Medical Advisor op de cardiovasculaire business unit van Sanofi-Synthelabo in Maassluis gewerkt. In 2000 werd zij als arts-onderzoeker van de MIND. IT studie voor de locaties Maastricht en Heerlen aangesteld op de afdeling Psychiatrie van het Academisch Ziekenhuis van Maastricht en werd "Etiologische aspecten van depressie na een hartinfarct" het onderwerp van haar dissertatie. 
ISBN 90-6464-019-X
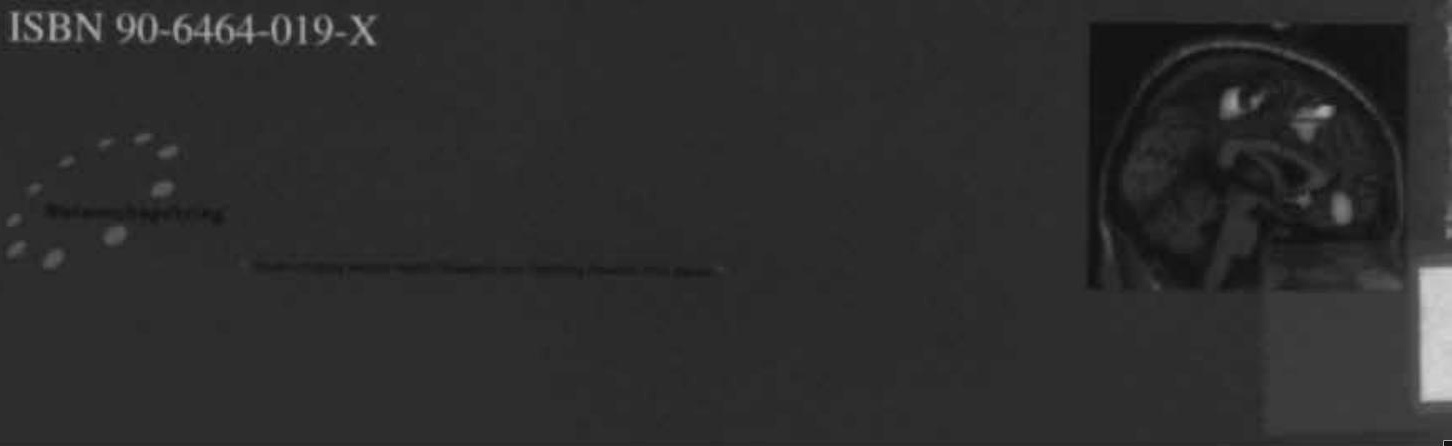